\title{
LA ALJAMA JUDÍA DE JACA \\ EN LA ÉPOCA DE LA DISPUTA DE TORTOSA \\ $(1410-1420)$
}

\author{
Miguel ANGEl Motis Dolader \\ Universidad de Zaragoza \\ ELIEZER GUTWIRTH \\ University of Tel Aviv
}

\begin{abstract}
SUMARIO
0. Introducción.- 1. Contexto histórico.- 1.1. Los prolegómenos: alteraciones finiseculares.- 1.2. Las conversiones.- 1.3. Disposiciones restrictivas de la Bula de Benedicto XIII.- 1.3.1. Económicas. a) El comercio. b) Préstamos usurarios.- 1.3.2 Religiosas.- 1.3.3. Código de segregación indumentaria: la rota.- 1.4. Conclusión de las negociaciones y derogación parcial.- 2. La población.- 3. Configuración política.- 3.1. Los órganos judiciales.- 3.2. Los órganos de gobierno.- 3.2.1. La aljama.3.2.2. Los adelantados.- 3.3. El notariado.- 4. La articulación social.- 5. Hacienda y finanzas.- 5.1. Sistema tributario.- 5.1.1. Emisión de deuda pública. a) Deuda a corto plazo: las comandas. b) Deuda a largo plazo: los censales.- 5.1.2. Gastos. a) Ordinarios. b) Extraordinarios.- 6. Hábitat urbano.- 6.1. El barrio y su situación.- 6.2. Inmuebles de uso privado.6.3. Inmuebles de utilidad pública.- 7. Geografía económica.- 7.1. Explotaciones agrarias.- 7.2. El sector comercial y artesanal.- 7.3. El sistema crediticio.
\end{abstract}

\section{INTRODUCCIÓN}

El marco cronológico escogido gira en torno al año 1415, en que se procede al inventario y decomiso de los libros poseídos por los judíos de Jaca, como consecuencia de la puesta en práctica de los dictados papales contenidos en la Bula de Benedicto XIII. La relación - fragmentada - ha 
llegado a nuestro poder tras una laboriosa catalogación de los papeles sueltos procedentes de los protocolos notariales jacetanos ${ }^{1}$. Para evitar centrarnos en un sólo año, con las deficiencias que ello acarrearía, hemos extendido nuestro estudio la década comprendida entre los años 1410 y 1420.

Se persigue, además de llevar a cabo un estudio de las piezas librarias inventariadas por los comisarios pontificios en los domicilios de alguno de sus más instruidos hebreos, trazar una breve semblanza de la aljama en los tiempos de la Disputa de Tortosa, como referente histórico en el que se genera el documento.

Las fuentes manejadas han sido fundamentalmente notariales, lo que, sin duda, condiciona nuestro discurso. No son muy numerosos los protocolos conservados de la época, especialmente los comprendidos entre 1415 y 1420 , a causa tanto de la destrucción documental en sí misma como de una patente contracción de la actividad económica. Estas lagunas son aún mayores si atendemos a los registros que han permanecido íntegros, pues muchos no son sino cuadernillos u hojas sueltas ${ }^{2}$.

No obstante, alguno de ellos son especialmente válidos, como los atribuidos a Miguel Alamán, que ostentaba, como reseña en el prólogo anual de sus colecciones notales, el cargo de «scrivano de la aljama de los judios» ${ }^{3}$. Tenemos constancia, por tanto, de que por sus páginas desfila, en el período de su ejercicio profesional, gran parte de la producción documental de la aljama y sus miembros en sus relaciones económicas con la población cristiana, dado que cuentan para los asuntos intracomunitarios con un gabinete notarial propio ${ }^{4}$. Por otro lado, y como nunca hemos sido partidarios de cimentar nuestros estudios en un solo apoyo documental - siempre y cuando ello ha sido posible - se han complementado con piezas

\footnotetext{
'Agradecemos a María Rivas y María Carmen Susín, directora y subdirectora respectivamente del Archivo Provincial de Huesca, todas las facilidades dispensadas en el transcurso de nuestras investigaciones, al igual que a todo el personal que nos atendió.

${ }^{2}$ Relación sumaria de los principales protocolos empleados: $n^{\circ}$. 8112 (1410); 8113 (1412); 8114 (1414); 8115 (1416); 8116 (1417); 8666 (1410); 8667 (1413); 8668 (1414); 8669 (1419); 8712 (1415); 8720 (1413); 8722 (1418); 8724 (1420); 9898 (1420).

${ }^{3}$ El ejercicio profesional de este notario es extraordinariamente dilatado pues, todavía en 1448, sigue desempeñando esta función. Manuel GóMEZ DE VALENZUELA, La actividad mercantil de los judíos de Jaca y Huesca en el Alto Valle del Gállego (1426-1487), "Argensola", 101 (1988), docs. 48 \& 52.

${ }^{4} \mathrm{Cfr}$. Miguel Angel Motis Dolader, Los judios de Jaca en el siglo XV, Zaragoza, 1996 (en prensa)
} 
procedentes de la Cancillería Real y del Concejo ${ }^{5}$, a fin de establecer un correlato entre las disposiciones legales - marco teórico-y su aplicación en la ciudad -marco práctico-.

\section{CONTEXTO HISTORICO}

Nos encontramos en un período en que tanto la iglesia como la monarquía no cejan en su empeño por inculcar los valores ideológicos y prácticos de la religión católica dominante, sin reparar en los medios.

Las persecuciones de finales de siglo - sangrientas en ocasionesse habían revelado inadecuadas por la estela de conversiones incinceras que dejó a su paso - uno de los fermentos de la expulsión - . El siglo XV nacerá al compás de nuevos replanteamientos que ponen énfasis en la catequesis y en la persuasión doctrinal ${ }^{8}$. No obstante, a la par prendió con fuerza un rígido sistema segregativo que contribuyó a debilitar las maltrechas estructuras de esta minoría.

\subsection{Los prolegómenos: alteraciones finiseculares}

Nuestra judería se hallaba convaleciente de los efectos producidos por la inestabilidad interna y los conatos de violencia - con resultado de muerte y destrucción de bienes- de que fue objeto. Una de las situaciones más tensas se produjo con motivo de «la cruzada de los pastores», que estuvo a punto de colocarla al borde de su extinción física. En efecto, en 1320 se

${ }^{5}$ Principales siglas utilizadas:

- ACA, Archivos de la Corona de Aragón. Barcelona.

- ADZ, Archivo de la Diputación Provincial. Zaragoza.

- AHPH, Archivo Histórico Provincial de Huesca. Sección Protocolos de Jaca.

- AHPZ, Archivo Histórico de Protocolos de Zaragoza.

- AMJ, Archivo Municipal de Jaca.

${ }^{6}$ En general, para este período Miguel Angel Motis DOLADER, Los judios del reino de Aragón en la Edad Media (siglos XII-XV), Zaragoza, Caja de Ahorros de la Inmaculada, Colección Mariano de Pano, 1990.

${ }^{7}$ Miguel Angel Motis Dolader, La expulsión de los judios del Reino de Aragón, Zaragoza, Diputación General de Aragón, Departamento de Cultura, 1990, vol. I, pp. 59-63.

${ }^{8}$ Miguel Angel Motis Dolader, La expulsión de los judios aragoneses, "Destierros aragoneses. I. Judíos y Moriscos. Ponencias y Comunicaciones", Zaragoza, Institución Fernando el Católico, 1988, pp. 73-79. 
reunió en Francia, bajo la dirección de un visionario popular, una muchedumbre incontrolada y alborotada de gentes desordenadas que recibieron el nombre de pastorelli ${ }^{9}$, con objeto de iniciar una cruzada contra los musulmanes de Granada. Tras dar muerte a muchos judíos del sur francés, especialmente Tolouse, atravesaron los Pirineos y entraron en Aragón, deteniéndose en las juderías de Jaca y Montclús ${ }^{10}$.

Las crónicas judías relatan el horror de la comunidad judía jacetana cuyo barrio fue pasto de unas llamas voraces que destruyeron parte de su caserío $^{11}$. Según Yosef Ha-Cohén, en este año perdieron la vida en torno a cuatrocientos judíos y sólo pudieron salvarse en torno a diez ${ }^{12}$. En nuestra opinión esta mortandad no es fácilmente asumible ya que cincuenta años después las fuentes fiscales dejan constancia de unos efectivos que sobrepasan los 425 habitantes $^{13}$. Aunque no dudamos de que muriera un número elevado de judíos, intuimos que se produjo una huida masiva, cuyos fugitivos retornàrían al extinguirse los disturbios. De hecho, existen pequeñas juderías en las proximidades - Luesia, el Frago, Biel, Ruesta, Uncastillo- con cuya hospitalidad pudieron contar ${ }^{14}$.

Poco tiempo después, la peste negra, que se extendiò endémica por toda la península desde 1348, alteró los ánimos, concitando a la violencia. En un documento emitido el 17 de abril de 1350 se da cuenta de los luctuosos hechos acaecidos el Jueves Santo, en que numerosos cristianos, con la complicidad de la noche, "venerunt ad ebreismum civitatis et januas predicte judarie conantes intrarunt jungiter expugnarunt ac violenter eas fregerunt et aperierunt et ex quo fuerunt intus, plures de dicto abreismo domus raubarunt judeosque comorantes resistere dictum raubariam et violentiam cum gladiis persecusserunt». Este estallido incontrolado se reprodujo en la noche del Viernes Santo. Entre las víctimas se encontraba el escudero Gerando Devin, encargado de custodiar la judería. El rey,

\footnotetext{
${ }^{9}$ Joaquín MiReT y SANS, Le massacre des Juifs de Montclus en 1320. Épisode de l'entrée des Pastoureaux dans l'Aragon, "Revue des Etudes Juives", 53 (1907), pp. 255-66.

${ }^{10}$ Yitzhak BAER, Historia de los judíos en la España Cristiana, Madrid, Editorial Altalema, 1981, pp. 317-18.

"Yitzhak BAER, Historia de los judíos en la España Cristiana, p. 397.

${ }^{12}$ Emeq ha-bajá, ed. M. Letteris, Viena, 1852, p. 60.

${ }^{13}$ Vide infra.

${ }^{14}$ Miguel Angel Motis Dolader, Judíos y judeoconversos de la Raya Occidental del reino de Aragón, "Borja y la Raya Occidental en Aragón. Ponencias", Zaragoza, Institución Fernando el Católico, 1993, pp. 45-186.
} 
indignado, conminó a un castigo ejemplarizante a los cabecillas de modo que «eorum pena cedat ad flagitium» ${ }^{15}$. Ya con anterioridad, el merino de Jaca - del que se ha conservado el libro de cuentas del año 1387-1399- asentaba en el capítulo de las caloñas ${ }^{16}$ algunos homicidios cometidos contra los judíos, cuyo importe ascendía, por fuero, a 500 sueldos $^{17}$.

La pacífica convivencia de ambas comunidades sufrió nuevos sobresaltos, si prestamos atención a las quejas que en 1383 los procuradores de la aljama elevan al infante don Juan. Alegan las continuas vejaciones de que eran objeto por parte de los cristianos los cuales se internaban en el recinto sin licencia, provocando constantes disturbios con sus danzas y solaces. El infante, atendiendo las súplicas de sus vasallos, y en nombre de la reina, lanzó interdicto contra todo aquél que así actuara, no permitiendo que entraran en el recinto más que dos o tres jurados ${ }^{18}$. Los transgresores serían sancionados con una multa de cien sueldos u otros tantos días de prisión en la cárcel de la ciudad si se declaraban insolventes. Su observancia se encomendaba al baile y a los jurados de la ciudad ${ }^{19}$. Su efectividad no fue muy operativa desde el momento en que esta orden debía pregonarse anualmente ${ }^{20}$.

\footnotetext{
${ }^{15}$ Amada LÓPEZ DE MENESES, Una consecuencia de la peste negra en Cataluña: el pogrom de 1348, "Sefarad", XIX (1959), pp. 129-130. \& ACA, Real Cancillería, Reg. 561, fol. 8 v.-9. Cit. Ricardo del ARCO, Las juderias de Jaca y Zaragoza, "Sefarad", XIV (1954), p. 80 (3.iv.1350)

${ }^{16}$ Estas rentas habían sido asignadas por cámara a la duquesa de Gerona, doña Violante, [María Luisa LEDESMA RUBIO, El Patrimonio real en Aragón a fines del siglo XIV, "Aragón en la Edad Media", II (1979), p. 138]. ver fol. V v. p. 146 y la difamación de otro judío p. 149 fol. IX $v$.

${ }^{17}$ María Luisa Ledesma Rubio, El libro de Cuentas del Merino de Jaca (Años 1387 a 1399), "Aragón en la Edad Media", I (1977), p. 146. La difamación se tasaba en la quinta parte [Ibidem, p. 149].

Vid. etiam Mauricio MolHo, El Fuero de Jaca, Zaragoza, Escuela de Estudios Medievales, 1964, pp. 129-130, redacción A. 232. El rey recibe la totalidad de la caloña. Vid. ibidem p. 118, A. 208: «XIX. De omicidi».

Ya en la compilación de los Fueros d Aragón realizada por Vidal de Canellas [Vidal Mayor, Edición de Gunnar TILANDER, vol. II, Lund, 1964] se señala como la contraprestación económica más difundida (IX. 60-38).

${ }^{18}$ Precisamente, uno de los más potentados judíos jacetanos, Judas Avingoyos, mayor, hijo de Azarian, «firmava vasallage», el 27 de enero de 1419, al infante don Juan por tiempo de 12 años percibiendo por esa infeudación 2 florines de oro anuales [AHPH, Protocolo 8 669, Jaca, 1419, fol. 26].

${ }^{19}$ Ledesma, El Patrimonio real en Aragón, p. 153.

${ }^{20} \mathrm{ACA}$, Cancillería, reg. 1808, fols. 110-110 v.
} 
La extenuación material que atravesaba favoreció que en 1391 funcionaran los dispositivos de seguridad y defensa de la judería, motivo que produjo el reconocimiento y agradecimiento de la reina, noticiosa por su marido y el vizconde de Roda, camarlengo suyo, de que por «la gran e subirana cura que havez havido en la deffension e tuicion de la aljama nuestra de los judios de aquexa ciudat». No por ello deja de recomendarles que no bajen la guardia pues los tiempos difíciles no habían sido sofocados: «si bien lo havedes començado entro aqui lo querades daqui adalant continuar de bien en mellor, de manera que, mediant vuestra buena industria e diligencia la dita nuestra aljama e singulares de aquella sian preservados de todo sinistro, danyo e concitacion ${ }^{21}$.

Los repetidos asaltos sufridos en las festividades cristianas $^{22}$ y la sensación de vulnerabilidad en las recientes alteraciones, allanó el camino para abrir las negociaciones con el municipio, lo que condujo a la rúbrica de unos capítulos sobre la custodia de la judería. Este se mantuvo en vigor hasta el mismo instante de la expulsión. Sin embargo, un situación económica cada vez más precaria obligará, en 1475 , a reducir el canon de 240 sueldos $^{23}$ a 160. Paralelamente, la dotación de seis jurados se rebajó a cuatro, por lo que es obvio que cada agente de seguridad percibía por este supuesto 40 sueldos anuales ${ }^{24}$.

\subsection{Las conversiones}

Las fuentes de la época, tanto cancillerescas como locales no se muestran muy elocuentes a la hora de referirse a las consecuencias conversoras en tan difíciles momentos para la judería hispana; no consta en las actas siquiera el envío de representantes a la corte tortosí ni su incidencia sobre el espíritu y las creencias de sus feligreses ${ }^{25}$. Al menos tenemos la

\footnotetext{
${ }^{21}$ ACA, Cancillería, reg. 2054, fol. 103. Pub. Fritz BAER, Die Juden im Christlichen Spanien. Erster Teil. Urkunden und Regesten. I. Aragonien und Navarra, Berlin, 1929/1936, doc. 426.

${ }^{22}$ Jean RÉGNÉ, History of the Jews in Aragon. Regesta and Documents (1213-1327), Hispania Judaica, 1, Jerusalem, The Magnes Press, The Hebrew University, 1978, doc. 1035.

${ }^{23} \mathrm{Se}$ abonaban en dos tandas de 120 sueldos por la guarda del Viernes Santo y por la «exida del anyo", es decir en Navidad.

${ }^{24}$ AMJ, Actos Comunes, fol. 53.

${ }^{25}$ Chebet Jehuda, Edición Francisco CANTERA BuRgos, pp. 168-169.
} 
certeza de que la onda expansiva no se dejó sentir con virulencia por cuanto al confrontar la onomástica de las personas que se documentan en los protocolos notariales antes y después del bienio 1414-1415, ésta permanece estable y sin cambios apreciables ${ }^{26}$.

Verificábamos en otras ocasiones cómo cuando la judería padece unas fuerte recesión material o económica la debilidad estructural del área no se permite la licencia de cercenar la minoría judía si desempeñaba un importante papel en el equilibrio de las fuerzas económicas ${ }^{27}$. Uno de los pocos indicios que poseemos, si no el único, lo testimonia un acto de donación llevado a cabo el 28 de diciembre de 1418 por Pero Sparça, sastre, y su hijo Leonart, habitantes en Jaca, a Eçer, judía, madre del primero, de unas casas en la judería ${ }^{28}$. Es factible pensar que la presión a la que fueron sometidos con las predicaciones semanales y el viaje realizado por micer Vicent Ferrer, coaccionó la libertad de las prácticas religiosas, causando conversiones forzadas, que no trascendieron de un segmento marginal de la sociedad, cuantitativamente hablando.

\subsection{Disposiciones restrictivas de la Bula de Benedicto XIII}

Un duro período de crisis institucional y socio-económica se abre tras la Disputa de Tortosa, no tanto por las fuertes corrientes de apostasía como por la incidencia de una ofensiva legislativa de inspiración eclesiástica que llega a turbar el normal discurrir de las actividades profesionales, económicas y religiosas de esta judería altoaragonesa.

Al abrigo de una carta fechada el 25 de agosto de 1414, endosada al capítulo, justicia, prior, jurados y procuradores de Jaca, sabemos de las quejas elevadas por los adelantados de la aljama, tras la reciente visita de Vicente Ferrer quien les indujo a otorgar «ordinaciones muyt rigorosas»,

\footnotetext{
${ }^{26}$ Ver también su omisión en Jerónimo ZURITA, Anales de Aragón, libro XII, cap. XLV p. 416. Edic. Ángel CANELlAS LóPEZ, Institución Fernando el Católico, CSIC, Zaragoza, 1980, vol. 5.

Cfr. las menciones a las conversiones que se citan en las mismas actas. A. PACIOS, La Disputa de Tortosa. Madrid-Barcelona, 1957, vol. I, sesión 12, p. 63; sesión 14 pp. 63-64.; pp. $65-66 ; 74$ y 76.

${ }^{27}$ Algo similar ocurre en Tarazona. Miguel Ángel MoTIS DOLADER, Convulsiones finiseculares y conflictividad social: la aljama judía de Tarazona y las alteraciones de 1391, "Primer Encuentro Nacional sobre la Comarca del Moncayo. Ciencias sociales", Tarazona, 1992, vol. I, pp. 191-224.

${ }^{28} \mathrm{AHPH}$, Protocolo 8669, Jaca, 1419, fols. 2 v. -3.
} 
entre cuyos supuestos destaca: la prohibición de vender pan, molerlo en el molino o cocerlo; la amenaza de amputación del pie a todo judío o judía que entrara en casa de cristiano; restricciones en la venta de ciertos productos de primera necesidad como trigo y vino; cierre inmediato de las tiendas situadas en el exterior de la judería y obligación de portar «una grand rueda ${ }^{29}$.

El impacto de su entrada en vigor había resultado tan pernicioso que los rectores aljamiales advierten que si no desistían en su observancia habrían de evacuar la ciudad «e transportar sus domicilios en otras partes $»^{30}$. El rey, conocida la situación, prohibe que las autoridades procedan contra los judíos y sus bienes, restableciendo la garantía de integridad personal y patrimonial que existía antes de la visita del dominico ${ }^{31}$.

Estas instrucciones no fueron cumplidas al pie de la letra por requerir nuevos mandatos fechados el 4 de septiembre de 1414, enviados a la Seo, donde se expone la situación creada con estas ordinaciones que pretendían poner-en marcha el espíritu de Tortosa: «no procedissan en alguna manera cuentra a els dits judios ni bienes ni cosas deilos, antes tractassen aquells en fazer los habitar segurament en sus casas e ir por todas las ditas montanyas como en fazerlos vender e dar todas cosas a ellos necessarias» ${ }^{32}$.

Sin embargo, de nuevo, los adelantados hubieron de comunicarle que el vicario general y los oficios del reino, bajo pena de excomunión, habían amonestado a los habitantes de la ciudad y sus montañas para «que no acugan en sus casas judios ne judias algunos nels venden trigo ne vino ne carnes ne no molgan ne cogan pan a los forns nels venden mercaderias algunas ne de ellos campran algo» ${ }^{33}$. La situación alcanzó gran tensión al interponer pleitos criminales contra los jurados de Jaca por las reiteradas transgresiones de los privilegios que habían sido novados por su alteza, tal

\footnotetext{
${ }^{29} \mathrm{ACA}$, Cancillería, reg. 2451, fol. 61. A estas mismas ordinaciones se refiere en una carta cursada a su tía Doña Violante el 27 de octubre de 1414. ACA, Cancillería, reg. 2407, fol. 99.

${ }^{30}$ En una situación muy similar se encuentra la judería de Daroca [Miguel Angel Motis DOLADER, Disappearance of the jewish community of Daroca at the beginning of the XVth. Century, "Tenth World Congress of Jewish Studies", Division B, Volume II, Jerusalem, 1990, pp. 143-150] o Calatayud [Ovidio CUELLA EsTEBAN, Los judios bilbilitanos en tiempos del Papa Luna, "Papeles Bilbilitanos, Primer Encuentro de Estudios Bilbilitanos", II, Calatayud, 1983, pp. 133-140]

${ }^{31}$ ACA, Cancillería, reg. 2445, fols. 130-130 v.

${ }^{32} \mathrm{ACA}$, Cancillería, reg. 2452, fols. 61-61 v.

${ }^{33} \mathrm{ACA}$, Cancillería, reg. 2451, fols. 61-61 v.
} 
y como queda patente por sendas misivas regias datadas el primero de octubre de $1414^{34}$.

La perduración de este corpus reglamentista hubiera llegado a socavar los cimientos de la comunidad judía. Empero, la previsible degeneración en el tejido socio-jurídico no llegó a producirse gracias a las negociaciones emprendidas con los monarcas a través de los representantes de las aljamas a nivel local y del reino y del propio interés de aquéllos - contenido el celo proselitista a ultranza de los primeros momentos a instigación de las autoridades eclesiásticas-por mantener una de sus fuentes de ingresos, aunque éstas cada fueran más secundarias ${ }^{35}$. El período de negociaciones dio comienzo en 1415 -cuando Fernando I se encontraba en Igualada - al establecerse los primeros contactos mediante legados de la aljama, no concluyendo hasta cuatro años después con la derogación de los reglamentos más lesivos y la flexibilización de los más conflictivos. En su glosa los hemos agrupado en epígrafes temáticos.

\subsubsection{Económicas}

En este terreno prestaremos atención a dos parcelas muy relevantes como son el sistema crediticio y los intercambios comerciales.

\section{a) El comercio}

Las disposiciones de la Ordinación no les permitían comerciar con los mudéjares; les prohibía el ejercicio de la correduría o intermediación comercial, retirando las licencias a quienes la poseyeran y les impedía alquilar casas o tiendas fuera de la judería siempre y cuando los propietarios fueren cristianos. Caso en contrario, los titulares de los inmuebles se exponían a su decomiso ${ }^{36}$. Estas admoniciones hubieron de ser reconducidas, pues los judíos constituían una de las piedras de toque del sistema

\footnotetext{
${ }^{34}$ ACA, Cancillería, reg. 2445, fols. 171 y 177.

${ }^{35}$ Cuando esta argumentación no servía al no poder atender una aljama determinada sus obligaciones fiscales su existencia tenía los días contados. Motis, Disappearance of the jewish community of Daroca, op. cit.

${ }^{36}$ Francisca VENDRELL, En torno a la confirmación real en Aragón de la Pragmática de Benedicto XIII, "Sefarad", XX (1960), p. 334.
} 
comercial y financiero de la ciudad cuyo sistema productivo no estaba todavía preparado para prescindir de ellos.

Los judíos juegan un papel irrenunciable como agentes comerciales, computándose a fines de siglo, en que disponemos de una muestra mucho más significativa, un $8 \%$ de la población activa, especializándose en la llamada correduría de oreja ${ }^{37}$. En consonancia, por los daños que se generaban se les concede licencia para que tengan tiendas en el barrio cristiano donde vender sus mercancías durante el día - estaba prohibido pernoctar en ellas o realizar cualquier tipo de trabajo fuera del horario comereial-. Por otro lado, el capitán de Jaca, el justicia y los jurados no pondrían reparo alguno al comercio con los moros financiado por corredores judíos sin imponerles por ello multa alguna ${ }^{38}$.

En este mismo orden de cosas queremos dejar constancia de una carta partida por $\mathrm{ABC}$ que se ha conservado muy fragmentada ${ }^{39} \mathrm{y}$, en alguna de sus líneas, ilegible, en las guardas de un protocolo de 1410 . Aunque se ha perdido la fecha, el acuerdo que en él se establece se sitúa en la época que estudiamos, si nos basamos en los otorgantes. El tenor documental responde a un acuerdo establecido en la Seo de Jaca por los «cofrades de los menestrales, çapateros e judios de la ciudat», representados legalmente por Bonaffos Gallipapa y Juce Abambron, hijo de Faranel, con los capellanes del capítulo, gracias a la arbitración de Johan Capellan por «su antiguidat, buena fama a Dios e su buena conciencia».

La querella se había suscitado con respecto a «las tiendas do ellyos e otros judios de la dita aljama obravan e cosian en las carreras de la cristiandat de la dita ciudat de Jaca». Escuchadas las alegaciones de los petentes de justicia y «por tirarse de scandalos e males», el clérigo resuelve que como único medio de que no se les impidiera «coser ni obrir por coser las ditas tiendas», los artesanos judíos deberían observar las festividades

\footnotetext{
${ }^{37}$ Miguel Ángel Motis DolaDER, Los judios de Jaca en el siglo XV, op. cit.; y Corredores judios en Aragón en la Baja Edad Media, "Aragón en la Edad Media: Estudios de Sociedad y Economía", VII (1985), pp. 97-155.

Además, en tiempos de Jaime - en 1272- uno de sus componentes, Mosse Elnieto, obtiene vitaliciamente una escribanía clave como es la del almudí y el oficio de la medida de la rasa, con el derecho e unificar la medida del trigo y otros cereales y de percibir por su trabajo diariamente cuatro dineros jaqueses [Jean RÉGNÉ, History of the Jews in Aragon, doc. 538].

${ }^{38}$ VENDRELL, En torno a la confirmación real en Aragón, p. 334.

${ }^{39}$ Aproximadamente un cuarto de su extensión en su margen derecho y otra superficie similar en el derecho se ha perdido.
} 
cristianas, absteniéndose de todo trabajo fabril y de toda venta (quizás subyace un problema extrarreligioso de competencia gremial $)^{40}$.

Para evitar cualquier equívoco se da cuenta del calendario litúrgico no laborable en la ciudad ${ }^{41}$ : todos los domingos, la Pascua de Navidad y tres días después, la Pascua de Resurrección y dos días después, la Crucifixión de Cristo, San Salvador, San Antón, Santa María Candelaria, Santa María de Marzo, San Jorge, San Marcos, San Felipe y San Jaime, la Ascensión, El Corpus Cristi, San Juan Bautista, Santa Orosia - patrona de la ciudad-, San Juan y San Pablo, San Pedro, Santa María Magdalena, Santa Ana, San Jaime, Santa María de Septiembre, Todos los Santos, Santa Catalina [?], San Simón y San Judas, la Expiración de la Virgen, San Andrés, Santo Tomás. Tenemos por cierto que esta prohibición afectaba tan sólo a los establecimientos comerciales situados en el barrio cristiano, pues este precepto no podía hacerse extensivo a los obradores y puntos comerciales de la zona judía que tenían sus propios días feriados. Los judíos «acceptavan et acceptaron aquella e cada una dellas et prometieron e se obligaron ${ }^{42}$. En definitiva, no tenían otra alternativa que plegarse a las pretensiones de los gremios cristianos si no querían ver peligrar estos enclaves comerciales que atendían el mercado textil y de la piel de una parte de la ciudad judío y las aldeas de los alrededores.

\section{b) Préstamos usurarios}

El artículo $12^{\circ}$ regulaba el controvertido tema de las usuras -préstamo con interés- mientras que el $13^{\circ}$ prohibía a los notarios cristianos la formalización de documentos usurarios y la reclamación por vía notarial y ejecutiva de las mismas. Las consecuencias inmediatas que se derivaron no se dejaron esperar: el saldo en el tráfico de bienes, servicios y capitales, que hasta entonces había sido favorable a los judíos, registró un índice cero o negativo y el préstamo de subsistencia, tan necesario en la comarca, se paralizó. A su vez los judíos dejaron de ingresar una parte fundamental de sus beneficios. Pronto se produjo una traslación de la crisis

\footnotetext{
${ }^{40} \mathrm{AHPH}$, Protocolo 8112, Jaca, 1410, cubiertas.

${ }^{41}$ Recuérdese que el documento ha llegado sensiblemente amputado, por lo que la nómina no es completa.

${ }^{42} \mathrm{AHPH}$, Protocolo 8112 , Jaca, 1410, cubiertas.
} 
a la esfera aljamal, pues el empobrecimiento de sus contribuyentes trajo consigo una disminución notabilísima de sus rentas que no bastaron para hacer frente a sus pagos corrientes. En definitiva, en la relación aljama-corona supuso un deterioro tributario y en el binomio judíos-cristianos una me:ma y ralentización del tráfico comercial tan necesitado de la emisión antelada de capitales.

Para paliar estos graves desequilibrios - de los que no llegó nunca a recuperarse- permitió que, «no obstante la prohibicion de usura, cada semestre pudieran capitalizar los préstamos con su correspondiente rédito pactados con anterioridad a la Pragmática ${ }^{43}$. Quedan al margen de esta resolución los censales y sus pensiones. Si los deudores no tuvieren numerario con los que responder, la responsabilidad pasaría a los bienes garantes de la operación que podrían ser ejecutados ${ }^{44}$.

\subsubsection{Religiosas}

De manera paralela se requisa la literatura religiosa judía ofensiva para el catolicismo triunfante tras la Controversia tortosí, uno de cuyos supuestos obliga a desplazarse a esta localidad a los comisarios instruidos por el pontífice para ocupar los libros del syllabus.

No menores altercados había causado la ordenación $16^{\mathrm{a}}$ referida a la asistencia de los judíos jacetanos tres veces al año a la predicación sobre el Evangelio y los dogmas cristianos ${ }^{45}$. Aquellos que rehusaban a comparecer a las sesiones doctrinales impartidas por el vicario general de la Seo sufrían coacciones y amenazas ${ }^{46}$. En los bandos previos a estos cónclaves se determinaba que serían obligados contra su voluntad: "por fuerça... e ço que peyor es, ha ferido e bastonayado algunos judios de la dita aliama ${ }^{47}$.

\footnotetext{
${ }^{43}$ Es decir, no se aplica la retroactividad.

${ }^{44}$ ACA, Cancillería, reg. 2390, fols. 337-338.

${ }^{45}$ Ya con anterioridad se habían verificado disturbios. Pedro III, en 1279, tras haber sido informado de que los predicadores y las órdenes menores cuando adoctrinaban en las sinagogas se llenaban de cristianos que acudían no con el animo de escuchar las homilías sino de escandalizar, reduce a 3 ó 4 el número de personas honorables que tienen permiso para asistir. Jean RÉGNÉ, History of the Jews in Aragon, doc. 746.

${ }^{46}$ Numerosas comunidades judías similares experimentan pánico por los desmanes con que, invariablemente, se acompañan estas actuaciones. v. gr. Aínsa. MoTIS, La expulsión de los judios aragoneses, pp. 67-112.

${ }^{47} \mathrm{ACA}$, Cancillería, reg. 2390 , fols. $84-84$ v.
} 
Consideradas desaforadas estas medidas se previene a Pedro Berán, baile de la urbe, de lo ilegítimo de comportamientos análogos a los referidos, imponiéndose una multa de quientos florines a los que hicieran caso omiso de esta prohibición. Como medida de gracia consiente el rey que no acudan sino un tercio cada $\mathrm{vez}^{48}$.

Pese a los esfuerzos y exhortos monárquicos por atemperar los constantes disturbios que se desencadenaban en toda judería, no mejoró el trato dispensado a los hebreos, si atendemos a la reiteración de las órdenes cursadas para garantizar su integridad. Sin ocultar su enojo, el rey invoca a Ramón Dezgurt, oficial real, y a Garcia de la Tenda, veguer general, que se cuiden de seguir hostigando e incitando al pueblo a levantamientos, asaltos y saqueos aprovechando sermones y procesiones, trasladándoles toda responsabilidad en los daños que sufran. La orden no admite réplica: «d'aqui adelant no presumades fazer ni permetades sieyer feytos danyos, vituperios ne males algunos a los ditos judios, antes desistades de las ditas inducciones e incitamentos fazer hayades aquellos en special recomendacion en todas cosas en quanto sea licito e deuto de honestat pueda sutenir» ${ }^{49}$.

\subsubsection{Código de segregación indumentaria: la rota}

La aplicación del ordenamiento $11^{\circ}$-la imposición de la rota bermeja y amarilla en lugar visible del pecho $^{50}$ - produjo numerosos perjuicios a los judíos que habían de desplazarse fuera de la ciudad en sus numerosos viajes por la comarca ${ }^{51}$, incitando a los salteadores de caminos y demás gentes de baja extracción a hacer de los judíos fáciles blancos de sus robos $^{52}$.

\footnotetext{
${ }^{48}$ ACA, Cancillería, reg. 2390, fol. 84. Cit. VENDRELL, En torno a la confirmación real en Aragón, p. 335.

${ }^{49} \mathrm{ACA}$, Cancillería, reg. 2390, fol. 78 v. Cit. VENDRELL, En torno a la confirmación real en Aragón, pp. 339-340.

${ }^{50}$ Tenía una anchura de cuatro dedos de diámetro de unos $38 \mathrm{~cm}^{2}$ de superficie -en otros lugares se apuntan seis piernas «del tamaño de un sello rodado»-. Cortes de los antiguos reinos de León y Castilla, vol. IV, p. 101.

${ }^{51}$ Rafael GIBERT, La paz del camino en el Derecho medieval español, "Anuario de Historia del Derecho Español", XXVII-XXVIII (1957-58), pp. 831-52.

${ }^{52} \mathrm{Los}$ anales registran casos de asaltos en villas próximas, como el acaecido en 1284 en que algunos vecinos de la villa de Enbún apresaron a un grupo de judíos en los bosques próximos pidiendo rescate tras desvalijarlos. Jean RÉGNÉ, History of the Jews in Aragon, docs. 1195 y 1196.
} 
En prevención de que la situación se hiciera insostenible y no osaran hacerse al camino les dispensa de su uso en sus desplazamientos, debiéndosela prender cuando llegaran a un lugar poblado — «quando los ditos judios caminantes o itinerantes o alguno d'ellos seran o passaran por algunas villas o lugares hayen e sien tenidos traher, levar e mostrar el sobredito signo o rueda assin como antes los acostumbraven levar» ${ }^{53}-$. Esta medida de gracia se puso en práctica también en Castilla por los abusos a los que había conducido ${ }^{54}$.

\subsection{Conclusión de las negociaciones y derogación parcial}

El quinquenio negocidador finaliza en 1419, en una reunión habida en la sinagoga en sesión plenaria convocada por el sammas o "sanogero», Jacob Almosnin, del 22 de junio "por tractar e desembargar los aferes e negocios de aquella», a instancia de los adelantados Azarian Avingoyos, hijo de Jacob, y Bienvenist Abendahuet. Responden a la convocatoria Açach Avingoyos, hijo de Azerian, Bonafos Alcala, hijo de Juce, Azarian Avingoyos, hijo de Judas, rabí Abram Avinpapur, Jahuda Abambron, hijo de Barjalá, Simuel Ampifaz, Mosse Babo, Salamon Almosnin, Açach Abambron, Açach Alcala, Barjala Alcala, Bonafos Abambron hijo de Açach, Sento Abambron, Azarian Almosnin, hijo de Salamon, Simuel Abambron, Bonafos Alcala, hijo de Mahir, Fahim Abambron, Barjala Sucran y Juce Avingoyos, hijo de Açach. Se encuentra también presente Alfonso de Orpesa, comisario y portero del rey, quien presenta una cédula y un memorial fechado en Barcelona el 7 de abril de 1419, donde se abordan las diversas prohibiciones que pesaban sobre las aljamas del reino de Aragón a raíz de los hechos referidos.

Del escrito se deduce que los agentes judíos consiguieron de la corona «algunas dispenssaciones por ciertas ordinaciones feytas sobre la manera del bivir de los ditos judios [que] eran prohibidos». El peso de las conversaciones se había encomendado a dos eximinos judíos - Vidal de la Cavalleria y Juce Abenafia- quienes habían logrado ciertas concesiones,

\footnotetext{
${ }^{53} \mathrm{ACA}$, Cancillería, reg. 2390 , fol. 83. Cit. VENDRELL, En torno a la confirmación real en Aragón, pp. 336-337.

${ }^{54}$ Emilio MITRE FERnÁNDEZ, Notas en torno a las disposiciones antijudias de las Cortes de Valladolid de 1405, "Seventh World Congress of Jewish Studies", Jerusalem, 1981, p. 119.
} 
previo pago de 3.000 florines de oro, de los cuales le correspondían a Jaca un total de 370 florines, es decir, un $12,3 \%$ del total del reino.

Satisfecha de los logros obtenidos, la aljama en pleno -el objetivo último de la reunión no es otro sino el de sancionar los acuerdos y garantizar el pago que les correspondía - se compromete a pagar a Bernard Sirvent, lugarteniente del tesorero real, pudiendo ejecutar, llegado el momento, incluso los bienes muebles de las viviendas judías ${ }^{55}$.

Tras este acuerdo da lectura al memorial -el segundo de los documentos que llevó a la reunión- «por razon de los traballos e muytas e diversas expenssas por don Vidal de la Cavalleria, fillo de don Jahuda, judio de Caragoça, feytas e sostenidas en nombre e voz de las aljamas de los judios del regno de Aragon en obtener del dito senyor rey muytas e diversas provisiones [e] disposiciones ${ }^{56}$. Los trabajos debieron ser muy onerosos a juzgar por el alto precio que les cupo, ya que se elevaba a 185 florines (la mitad que la derogación en sí misma) de los cuales habían sido satisfechos 85. Nuevamente se obligan a satisfacerlo ${ }^{57}$.

Estos compromisos no se llevaron a cabo pues, el 27 de noviembre de 1419, Johan Sthevan, portero del rey, habitante en Zaragoza, considerando que Vidal de la Cavallería le había presentado una letra ejecutoria del justicia de Aragón, dada en Zaragoza, el 3 de noviembre de aquel año, donde le mandaba que ejecutara los bienes de la aljama por un valor de 100 florines de oro, requiere a los adelantados - Azarian Avingoyos, Bienvenist Abendahuet y Salamon Ampifaz - para que lo cumplan. Ante esta severa amenaza le libran el dinero ${ }^{58}$. Un mes después -el 21 de diciembreAlfonso d'Orpesa, portero del rey, habitante en Zaragoza, procurador de Bernard Sirvent, lugarteniente de tesorero real, recibe 370 florines de oro, en cumplimiento de la carta pública que suscribieron en Jaca el 22 de junio de 1419.

No obstante, hemos de aclarar, que la propia aljama estaba empeñada en negociaciones al más alto nivel con la reina doña Violante, su señora natural, quien, al parecer, visitó personalmente la ciudad aprovechando para firmar provisiones favorables para su buen gobierno. La visita debió

\footnotetext{
${ }^{55} \mathrm{AHPH}$, Protocolo 8669, 1419, Jaca, fols. 74-77 v.

${ }^{56} \mathrm{AHPH}$, Protocolo 8669, 1419, Jaca, fol. 78.

${ }^{57} \mathrm{AHPH}$, Protocolo 8669, 1419, Jaca, fol. $79 \mathrm{v}$.

${ }^{58} \mathrm{AHPH}$, Protocolo 8669, 1419, Jaca, fols. 169-171.
} 
producirse poco antes del 4 de julio de 1417 , pues con esa fecha se asienta en los libros de tesorería de la soberana la recepción de 100 florines, «los quals donaren a la dita senyora reyna per que personalment havie yo visitat la dita aljama e per algunes provisions per mi a la dita aljama otorgades ${ }^{59}$. En el mismo ejercicio económico se refiere el pago de 50 florines de la cuota parte que correspondía a la reina de cierta «composicion» obtenida por los judíos jacetanos con el gobernador de Aragón ${ }^{60}$.

\section{LA POBLACION ${ }^{61}$}

Gracias a los fogajes realizados tras las Cortes celebradas en la villa de Maella en 1405, con el fin de amortizar las deudas del General del Reino, conocemos la población judía de algunas villas y ciudades aragonesas cuando se deslinda la población cristiana de la judía o mudéjar. Por desgracia en el caso jaqués no se produce así. Como punto de partida sabemos que los brazos de la iglesia, la nobleza y las universidades -en esta última categoría se incluirían los judíos aunque no tenían asiento en Cortes- tributarían por cada fuego o casa con 12 sueldos, mientras que si pertenecían a la caballería su cuota se reducía a 7 sueldos $^{62}$.

Sin embargo, un dato que incide directamente en nuestro estudio se refiere el número de fuegos globales de toda la ciudad que se elevan a $235^{63}$, con lo que la población - excluidos los francos-oscilaría en torno a las 1.050 personas $^{64}$. En este mismo manuscrito, en la sección correspondiente a las receptas - cuyos finiquitos se efectuaban en tres tandas a lo largo de otros tantos años- se asienta «Item, la ciudat de Jacca qui devia pagar con los judios por CCXXXV casas e no ha pagado sino por CL de christianos, assi que restan $\mathrm{LXXXV}{ }^{65}$. De esta escueta glosa podríamos

\footnotetext{
${ }^{59}$ Leopoldo PILEs Ros, Situación económica de las aljamas aragonesas a comienzos del siglo $X V$, "Sefarad", X (1950), p. 371.

${ }^{60}$ Ibidem.

${ }^{61}$ Cfr. Miguel Angel MotIs Dolader, Evolución demográfica de la comunidad judía de Jaca durante la Edad Media, "Homenaje a Don A. Durán Gudiol", Huesca, 1995, pp. 601-621.

${ }^{62} \mathrm{AHPZ}$, Fogajes de las Cortes de Maella, 1405, fol. 87.

${ }^{6.3} \mathrm{AHPZ}$, Fogajes de las Cortes de Maella, 1405, fol. $55 \mathrm{v}$.

${ }^{64} \mathrm{AHPZ}$, Fogajes de las Cortes de Maella, 1405, fol. $55 \mathrm{v}$

${ }^{65} \mathrm{AHPZ}$, Fogajes de las Cortes de Maella, 1405, fol. 94.
} 
inferir que, como máximo, el vecindario judío contaría con 85 casas, es decir, que oscilaría entre las $380-425$ personas $^{66}$, con lo que podría equipararse a núcleos tan importantes como Mallorca ${ }^{67}$ y Perpiñán ${ }^{68}$. Si de este apunte contable pudiera interpretarse que son únicamente los judíos los que restan por abonar la tarifa, el valor apuntado correspondería con el valor absoluto de la población. Subrayemos que esta cantidad coincide con los cálculos que se pueden inferir de la lista nominativa de la prorrata de $1377^{69}$.

Aunque estimamos que los apuntes anteriores son suficientes para establecer una población absoluta en torno a los 425 judíos $^{70}$, hemos elaborado una nómina de aquellos judíos y judías que aparecen en los protocolos notariales consultados ${ }^{71}$, es decir, con capacidad de obrar y contratar cuya condición, según la foralidad aragonesa, se obtiene tras cumplir la mayoría de edad plena. Dicho de otro modo, la población aquí reflejada cuenta al menos con 20 años ${ }^{72}$, por lo que, en justa lógica, no

\footnotetext{
${ }^{66}$ Sobre los distintos coeficientes empleados en demografía histórica vid. Miguel Angel Motis Dolader, Los judíos de Borja en el siglo XV, Borja, Centro de Estudios Borjanos, 1988, pp. 66-68.

Específicamente en el área jacetana algunos autores aplican la ratio de 4 miembros por unidad fiscal-familiar. Antonio SERRANO MONTALVO, La población altoaragonesa a finales del siglo $X V$, "Pirineos", 31-32 (1954), p. 215.

${ }^{67}$ José María QuAdRado, La judería de la capital de Mallorca en 13.91, "Boletín de la Real Academia de la Historia", IX (1886), pp. 294-312.

${ }^{68}$ Isidore LOEB, Histoire d'une taille levée sur les juifs de Perpignan en 1413-1414, "Revue des Études Juives", XIV (1887), pp. 55-79.

${ }^{69}$ David Romano, Prorrata de contribuyentes judios de Jaca en 1377, "Sefarad", XLII (1982), p. 16, donde se estipula entre 425 y 474 habitantes.

En 1471 -medio siglo después de nuestras disquisiciones - «en la adveracion de los fuegos» realizada por los jurados de turno - don García Loriz, prior, don Martin de Pomar de los Infançones, don Pedro d'Orant, don Martín de Foncanas, don Christoval Alaman y don Johan d'Arguis- contando los pater familias se contabilizan 74 casas susceptibles de pagar las sisas del reino. AMJ, Libro de Sesiones y Actas del Ayuntamiento 1451-98, caja 819, fol. 29.

${ }^{70} \mathrm{Cfr}$. Motis, Los judios de Jaca en el siglo XV, op. cit.

${ }^{71}$ Esta propuesta metodológica ha sido formulada repetidamente en los trabajos de D. Romano [Les juifs de la Couronne d'Aragon avant 1391, "Revue des Études Juives", CXLI (1982), p. 181]. En su elaboración hemos empleado las fuentes citadas en la nota 2.

Sobre lo pertinente del uso de las fuentes notariales con fines demográficos vid. J.P. PoIsson, Histoire des populations et actes notariés, "Annales de Démographie Historique", 1974, pp. 51-57.

${ }^{72}$ Los menores de 20 años no podrán hacer albaranes, definimientos, relajaciones ni remisiones ni donaciones ni a su tutor, curador, ni administradores, procuradores ni cualquiera otra persona. Ni tampoco pueda dar, vender, impignorar, cambiar de sus bienes sedentes hasta cumplida esa edad Liber $V$ Fororum Regni Aragonum, "De tutoribus, curatoribus, manumissioribus, spondalariis \& cabeçalariis». Pascual SAVALL y Santiago PENEN, Fueros,
} 
aparecen los hijos menores de edad o aquellos que, por cualquier circunstancia, en la década analizada no comparecieran ante notario cristiano.

No obstante, hemos de significar el elevado número de personas identificadas, muy por encima de los 115 nombres aportados por las listas fiscales. Este incremento cuantitativo de los efectivos individualizados tiene todavía más proyección que aquélla puesto que cuando ha sido posible, se cita su profesión - no señalamos los cargos aljamales si son electivos- $y$, lo que es más importante, su filiación ${ }^{73}$, con lo que corregimos los problemas de homonimia ${ }^{74}$. En algunos supuestos, para evitar la duplicidad, como es el caso de Sorbellita y Miriam, hijas de David Avingoyos, no cuentan con entrada propia, por no constar en los documentos como disponentes diplomáticos sino como sujetos pasivos de una donación de su tío $^{75}$. Las personas que se citan como extintos en 1410 no han sido consignados, aunque sí los que hubieren fallecido a lo largo de este período de diez años ${ }^{76}$, de tal modo que hemos tendido, además, a que todos los que procesamos sean convivientes.

He aquí el resultado de nuestras investigaciones, cuya lista recomendamos sea confrontada con la nómina de $1377^{77}$ y la de $1479-92^{78}$ :

ABAMBRON, Açach, padre de Barjala y Bonafos.

ABAMBRON, Barjala, hijo de Açach.

ABAMBRON, Barjala, hijo de Juce.

ABAMBRON, Bitas, hijo de Jacob.

ABAMBRON, Bonafos, hijo de Açach.

ABAMBRON, Fahim, hijo de Jahuda $(+)^{79}$, hermano de Faranell y Oro.

ABAMBRON, Fahim, hijo de Jacob y Ceti, y hermano de Mosse.

Observancias y Actos de Cortes del reino de Aragón, Zaragoza, 1866, vol. I, p. 238.

${ }^{73}$ «El parentesco entre los individuos sólo se señala en casos muy concretos». RoMANo, Prorrata de contribuyentes, pp. 9-10 y 17 .

${ }^{74}$ Obsérvese, por ejemplo, el caso de Juce Almonin con cuatro convivientes.

${ }^{75}$ Además existen censadas algunas judías casadas con este prenombre de las que no sabemos la identidad de sus progenitores. Podía suceder, por ejemplo, que Miriam fuera la mujer de Barjala Alcala y a su vez hija de David Avingoyos.

${ }^{76} \mathrm{De}$ ahí que algunas féminas tengan consignado el atributo de mujer/viuda

${ }^{77}$ Romano, Prorrata de contribuyentes, pp. 31-33.

${ }^{78}$ Omitimos a Juce Adich, casado con Jamila, yerno de Abram Lonieto, por ser habitante de Huesca.

${ }^{79}$ Salvo consigna en contrario el fallecido es el padre, es decir la persona que se sitúa inmeditamente anterior. 
ABAMBRON, Faranell, hermano de Oro y Fahim e hijo de Jahuda (+).

ABAMBRON, Jacob, alias Jacobet de Sos, casado con Ceti y padre de Mosse y Fahim.

ABAMBRON, Jacob, hijo de Jehuda.

ABAMBRON, Jahuda, hijo de Barjala $(+)$.

ABAMBRON, Jassuas, hijo de Juce $(+)$.

ABAMBRON, Juce, hijo de Faranell $(+)^{80}$, [zapatero?].

ABAMBRON, Mosse, hijo de Ceti y Jacob, hermano de Fahim.

ABAMBRON, Sento, hijo de Bonaffos.

ABAMBRON, Simuel, alias Cayatiel.

ABENACAYA, Abram, maestre, físico, casado con Jamila.

ABENACAYA, Fahim.

ABENANIAS, Abram.

ABENARDUT, Alazar.

ABENARDUT, Fahim.

ABENDAGUET, Azerian, maestre, físico, notario, padre de David.

ABENDAGUET, Bienvenist, casado con Sol.

ABENDAGUET, Davit, hijo de maestre Azarian, maestre (+), [físico?].

ABENDAVIT, Juce, maestre, cirujano $(+)$, mayor.

ABENDAVIT, Juce, menor, maestre, hijo de Juce $(+)^{81}$, [físico?].

ABENDAVIT, Mosse.

ACAYA, Juce, corredor.

ACAYA, Sento, menor.

ACAYA, Sento, alias Blanco.

ALAQUEN, Jahuda.

ALBORGE, Abram, alias Meolet.

ALBORGE, Simuel.

ALCALA, Abram, menor, hijo de Simuel ( + ).

ALCALA, Abram, mayor, padre de Simuel.

ALCALA, Açach, hijo de Abram (+).

ALCALA, Açach, hijo de Açach.

ALCALA, Açach, hijo de Barjala, casado con Astruga

ALCALA, Açach, hijo de Saçon (+), hermano de Barjala y Mahir.

ALCALA, Açach, padre de Açach.

ALCALA, Barjalá, padre de David.

ALCALA, Barjala, hijo de David (+) y nieto de Barjala,

ALCALA, Barjala, hijo de Saçon (+), casado con Meriam, hermano de Açach y Mahir.

ALCALA, Barjalá, hijo de Juce (+), corredor.

ALCALA, Bonafos, hijo de Juce, $(+)$, casado con Sol (hija de Menahem Ampifaz, $(+)$, hermano de Barjalá.

\footnotetext{
${ }^{80}$ Primera mención de muerte en 1419.

${ }^{81}$ Primera mención en 1413.
} 
ALCALA, Bonafos, hijo de Mahir (+).

ALCALA, Çaçón, hermano de Mahir, hijo de Sento ALCALA, alias Carido.

ALCALA, David, hijo de Barjala, casado con Oro, padre de Barjalá.

ALCALA, David, alias Cabador, hijo de Sento(+), casado con Bellita.

ALCALA, Eçer, viuda de Açach ABENMIELÇA, madre de Pero SPARÇA, sastre.

ALCALA, Jassuas.

ALCALA, Juce, hijo de Barjala.

ALCALA, Juce, hijo de Juce.

ALCALA, Mahir, hijo de Saçon, hermano de Barjala y Açach.

ALCALA, Mahir, hijo de Sento, alias Carido, hermano de Çaçón.

ALCALA, Saçon, hijo de Abraham (+).

ALCALA, Saçon, hijo de Sento y Duenya.

ALCALA, Saçon, hijo de Çaçon.

ALCALA, Sento, alias Carido, casado con Astruga, padre de Çaçón y Mahir.

ALCALA, Sento, alias SENTON, padre de Çaçon, casado con Duenya.

ALCALA, Simuel, hijo de Abram.

ALCALA, Simuel, hijo de Barjala.

ALCALA,-Simuel, hijo de Sazon, casado con Reina.

ALCASTIEL, Abram.

ALCASTIEL, Fahim.

ALEQUEFF, Jehuda.

ALEQUEFF, Juce.

ALEQUEFF, Simuel.

ALMOSNIN, Alatzar, hijo de Çaçón.

ALMOSNIN, Alatzar, hijo de Salamon.

ALMOSNIN, Astruga, viuda de Salamon AVINGOYOS.

ALMOSNIN, Azerian, hijo de Salamon.

ALMOSNIN, Azerian, hijo de Baruch (+), hermano de Salamon.

ALMOSNIN, Baruch, padre de Azerian y Salamon.

ALMOSNIN, Bonafos, hijo de Faranuel.

ALMOSNIN, Çaçón.

ALMOSNIN, Fahim (+) casado con Duenya.

ALMOSNIN, Jacob, hijo de Azerian, casado con Duenya.

ALMOSNIN, Jacob, hijo de Çaçon, sammas.

ALMOSNIN, Jacob, hijo de Faranel.

ALMOSNIN, Jacob, hijo de Juce (+).

ALMOSNIN, Jahuda, alias Leonet, padre de Juce.

ALMOSNIN, Juce, hijo de Jacob (+).

ALMOSNIN, Juce, hijo de Jehuda (+).

ALMOSNIN, Juce, hijo de Mahir.

ALMOSNIN, Mahir, rabí.

ALMOSNIN, Mosse.

ALMOSNIN, Salamon, alias Motes, hermano de Sento e hijo de Azerián (+).

ALMOSNIN, Salamon, hermano de Azarian, hijo de Baruch (+).

ALMOSNIN, Sento, menor, hermano de Salamon e hijo de Azerián (+). 
ALMOSNIN, Sento, hijo de Baruch $(+)$.

ALNIETA, Abram (+), padre de Astruga.

ALNIETA, Astruga, hija de Abram (+).

ALNIETA, Jamila, hija de Abram (+), casada con Juce ADICH judío de Huesca.

ALNIETA, Jassuas, hijo de Baruch.

ALNIETA, Juce.

ALNIETA, Mahir.

ALNIETA, Simuel.

ALTEXEFFI, Abram

AMATO, Salamon.

AMPIFAZ, Ceti, viuda de Judas AVINGOYOS y madre de Azerian.

AMPIFAZ, Juce.

AMPIFAZ, Menahem (+ en 1414), padre de Sol y Salbuenya, marido de Falbuenya.

AMPIFAZ, Mosse.

AMPIFAZ, Salamón, hijo de Juce (+).

AMPIFAZ, Salamón, hijo de Simuel.

AMPIFAZ, Salbuenya mujer de Azerian, hijo de Jacob (+).

AMPIFAX, Simuel.

ANACH, Jassuas.

ANDALI, Gento, hermano de Jassuas, casado con Sol.

ANDALI, Jassuas, hermano de Gento, casado con Sol.

ARAMA, Abram, sammas o sanoguero.

Aroça, mujer/viuda de David AVINGOYOS, alias Bonanat, hija de Salamon ALMOSNIN.

Astruga, mujer de Açach ALCALA.

Astruga, mujer de Sento ALCALA, alias Carido.

Astruga, mujer de Simuel LAVOR.

AVIFALEMA, Sasat.

AVINGOYOS, Açach, hijo de Jacob y Oro.

AVINGOYOS, Açach, hijo de Juce (+), casado con Miriam.

AVINGOYOS, Açach, rabino, hijo de Marian (1415) (o Azarian), casado con Duenya.

AVINGOYOS, Azerian, casado con Çeti AMPIFAZ, hijo de Judas (+), maestre, padre de Judas.

AVINGOYOS, Azerian, hijo de Jacob (+) y Oro, hermano de Açach AVINGOYOS, casado con Salbuenya AMPIFAZ.

AVINGOYOS, Azerian, hijo de Sento, (+), casado con Jamila, 1413

AVINGOYOS, Bitas (+ 1405).

AVINGOYOS, David, alias Bonanat, $(+)$, casado con Aroça y/o Ceti, padre de Sorbellita y Miriam.

AVINGOYOS, Jacob, hijo de Sento (+).

AVINGOYOS, Jacob, (+ en 1414), yerno de Abram LONIETO.

AVINGOYOS, Jacob, posiblemente casado con Oro, padre de Açach y Azerian.

AVINGOYOS, Juce, hijo de Açach (+).

AVINGOYOS, Juce, hijo de Sento (+). 
AVINGOYOS, Judas, mayor, hijo de Azerián y nieto de Judas, heredero de Bitas (+).

AVINGOYOS, Menahem, hijo de Azerian y de Salbuenya.

AVINGOYOS, Menahem, mayor.

AVINGOYOS, Salamon (+), casado con Astruga ALMOSNIN.

AVINGOYOS, Sento.

BABO, Faym.

BABO, Mosse.

Bellita mujer de David ALCALA, hijo de Sento.

BIVAG, Juce.

BIVAN, Jehuda.

ÇANA, viuda de Jucep ABAMBRON.

CARDINIEL, Jacob, alias Jacobon.

CARDENIEL, Juçep.

ÇARFATI, Baruch.

ÇARFATI, Jehuda.

ÇARFATI, Salamon.

CATRAX, Jassuas.

Ceti casada con Jacob ABAMBRON alias Jacobet de Sos, madre de Fahim y Mosse.

Duenya, casada con Jacob ALMOSNIN, hijo de Azerian.

Duenya, viuda de Fahim ALMOSNIN.

Duenya, casada con Açach AVINGOYOS.

Duenya, casada con Sento ALCALA, madre de Saçón.

Etçer, mujer de Azerian AVINGOYOS.

Eçer, viuda de rabí Haym.

Falbuenya, viuda de Menahem AMPIFAZ, don, hija de Salamon AVINGOYOS (+).

Falbuenya, casada con Juce PAPUR.

FAYENO, Ananías.

GALLIPAPA, Abram, hijo de Bonafos, hermano de Jucep.

GALLIPAPA, Azarian.

GALLIPAPA, Bonafos.

GALLIPAPA, Jucep, hermano de Abram.

HALEQUA, Sesat.

Jamila, mujer de maestre Abram ABENACAYA.

Jamila, mujer de Azerian AVINGOYOS e hija de Faym ALMOSNIN.

LAVOR, Azarian.

LAVOR, Fahim (Faym), zapatero.

LAVOR, Simuel alias Thema casado con Astruga.

LARROS, Açach, hijo de Junez, casado con Sol.

LARROS, Azerian.

LARROS, Juce.

LARROS, Junez, padre de Açach.

LONIETO, Abram, suegro de Juce ADICH y Jacob AVINGOYOS, padre de Jamila.

MAÇO, Açach.

MAÇO, Juce. 


\section{MAÇO, Salamon.}

MASCARAN, Davit.

Meriam, mujer de Barjala ALCALA.

Mira, mujer de Mosse TARIEGO.

Miriam, mujer de Açach AVINGOYOS, hijo de Jucep.

MOG, Sento.

Oro, hija de Jahuda Abambron, menor, hermana de Faranel y Fahim ABAMBRON.

Oro, mujer de David ALCALA, hijo de Barjala, madre de Barjalá.

Oro, mujer de Jacon AVINGOYOS, madre de Açach y Azerian.

Oro, mujer de Juce PLATERO.

Oro, mujer de Barjala SUCRAN

PAPUR, Abram, maestre, rabi.

PAPUR, Abram, menor, hijo de Alazar.

PAPUR, Alazar, padre de Abram.

PAPUR, Jacob.

PAPUR, Juce, menor, casado con Falbuenya.

PLATERO, Juce, argentero, casado con Oro.

Reina mujer de Simuel ALCALA, hijo de Sazon, (+).

Sol, casada con Açach LARROS.

Sol, casada con Bienvenist ABENDAGUET.

Sol, casada con Bonaffos ALCALA, hijo de Juce (+); hija de Menahem AMPIFAZ (+).

Sol, casada con Gento ANDALI.

Sol, casada con Josuas ANDALI.

Soli, viuda de Sento AVINGOYOS (+).

Sorbellita, viuda de rabí Simuel, heredera de don Bitas AVINGOYOS.

SPARÇA, Pero, sastre, converso, hijo de Eçer.

SUCRAN, Barjala, casado con Oro.

TAMI, Levi.

TARIEGO, Abram.

TARIEGO, Juce, hijo de Jahuda (+).

TARIEGO, Juce, menor, hijo de Chiquet.

TARIEGO, Salamon.

TORRE, Aya de la.

Probablemente esta no es una fuente idónea para profundizar en la estructura familiar pero sí lo es para avanzar algunas reflexiones. El primer dato objetivable es que se ha identificado un total de 206 personas $^{82}$ que cumplen un requisito esencial: tienen capacidad de obrar, lo que, en

\footnotetext{
${ }^{82}$ Evidentemente esta cifra puede experimentar incrementos fruto de ulteriores aportes documentales.
} 
términos de la doctrina jurídica aragonesa, se traduce en que han cumplido los veinte años de edad ${ }^{83}$.

La estructura reflejada es claramente nuclear, con un predominio de la familia conyugal. De los dos centenares de personas compulsadas existen 34 matrimonios $^{84}$ en que conocemos el nombre de ambos cónyuges ${ }^{85}$. Esta cifra es elevada si tenemos en cuenta que el índice de feminidad es tan sólo del $22,61 \%$, cuando debía alcanzar el $50 \%$. Obsérvese, además, que de estas 38 féminas 10 son viudas ${ }^{86}$. Esto no significa que un cuarto de la población femenina en edad de matrimonio hubiesen perdido a sus maridos. Esta proporción se debe a que las viudas pasan a ejercer de cabeza de familia y, por lo tanto, a otorgar documentos. La mujer casada aparece conjuntamente con su marido sólo para afianzar alguna solicitud de préstamo o aprobar enajenaciones o reducciones patrimoniales que pudieran afectar al consorcio

\footnotetext{
${ }^{83}$ Los mayores de 14 años y menores de 20 son mayores con una imperfecta capacidad o mayores cen aprendizaje vigilado, llamada también mayoría semiplena si no hubiesen contraídos nupcias, escapando a su capacidad exclusiva las facultades de los actos dispositivos más importantes. Cfr. Fuero «Ut minos viginti annorum», otorgado en 1381 y su glosa en ORTEGA SaN IÑIgO, Ut minor XX annorum, "Segunda Semana de Derecho Aragonés", Jaca, 1943, pp. 133 y ss y F. A., SanCho Rebullida, La edad en Derecho Aragonés, "Homenaje a J. Moneva Pujol", Zaragoza, 1954, pp. 341 y ss.

${ }^{84} \mathrm{La}$ tasa de nupcialidad en el Antiguo Régimen giraba en torno al 8 por mil. Vid. María concepción BURGO LÓPEZ, Niveles sociales y relaciones matrimoniales en Santiago y su comarca (1640-1750) a través de los escritos de dote. "Actas del II Coloquio de Metodología Histórica Aplicada. La Documentación Notarial y la Historia". I. Universidad de Santiago de Compostela, Junta de Decanos de los Colegios Notariales de España, Secretariado de Publicaciones de la Universidad de Santiago, Santiago, 1984, p. 179.

${ }^{85}$ Oro + Juce Platero; Oro + Barjala Sucran; Oro + Juce Platero; Falbuenya + Juce Papur; Ceti + Jacob Abambron; Jamila + Abram Abenacaya; Sol + Bienvenist Abendaguet; Jamila + Juce Adich (de Huesca); Astruga + Açach Alcala, hijo de Barjala; Meriam + Barjala Alcala: Sol + Bonafos Alcalá; Oro + David Alcala; Bellita + David Alcala; Duenya + Sento Alcala; Reina + Simuel Alcala, hijo de Saçon; Duenya + Fahim Almosnin; Duenya + Jacob Almosnin; Etcer + Azerian Avingoyos; Sol + Bienvenist Abendaguet; Sol + Açach Larros; Mira + Mosse Tariego; Oro + Jacob Avingoyos; Aroça + David Avingoyos; Jamila + Azerian Avingoyos, hijo de Sento; Astruga + Sento Alcala; Salbuenya + Azerian Ampifaz; Sol + Gento Avdali; Sol + Jassuas Avdali; Astruga + Simuel Lavor; Miriam + Açach Avingoyos; Duenya + Açach Avingoyos; Ceti + Azerian Avingoyos; Astruga + Salamon Avingoyos y Reina + Simuel Alcala.

${ }^{86}$ Sorbellida viuda de rabí Simuel; Eçer viuda de Açach Abenmielca; Astruga, viuda de Salamon Avingoyos, Ceti Ampifaz, viuda de Judas Avingoyos, Aroça, viuda de David Avingoyos; Cana, viuda de Juce Abambron; Duenya, viuda de Fahim Almosnin; Ecer, viuda de rabi Haym; Falbuenya, viuda de Menahem Ampifaz y Soli, viuda de Sento Avingoyos.
} 
del régimen económico de la pareja ${ }^{87}$. Pese a todo la tasa de viudedad, aunque probablemente no alcance el $25 \%$ sí debió ser muy elevada.

De los 77 casos en que conocemos la relación paterno filial con certeza, en 40 ocasiones los hijos mayores de 20 años son huérfanos por línea paterna, es decir, según nuestros datos, sólo un $48 \%$ de los hijos conocidos alcanza los 20 años sin que su padre haya fallecido. Ello refrenda la idea de que es inviable un modelo familiar puramente nuclear y la necesidad de establecer otros lazos de solidaridad, cuya base es precisamente la fragilidad familiar troncal, que por sí sola no puede asegurar la perpetuación generacional, sujeta a la probable muerte por enfermedad o accidente del cabeza de familia. Si consideramos que el hijo mayor de 20 años es, por definición, el primogénito o, al menos, uno de los mayores y que éste lo tuvo a la edad de 18-20 años, la longevidad media de los padres se situaría en torno a los 40 años. En este mismo sentido afirmar que el número de hijos supérstites mayores de edad oscila entre dos y tres ${ }^{88}$.

A fines del siglo $\mathrm{XV}$, donde conocemos en mayor detalle la estructura socio profesional, se demuestra que las familias que basan su subsistencia en la práctica de un oficio artesanal están especialmente amenazadas de extinción, tanto más cuanto más especializados en el oficio $^{89}$.

La unidad de convivencia y de producción judía es la familia, articulada en dos ámbitos. La doméstica, que convive en el mismo hogar, en torno al mismo fuego, compuesta por el matrimonio y los hijos no emancipados, y quizás el servicio doméstico y los aprendices; y la extensa compuesta por los hijos emancipados y en alguna medida los yernos y las

\footnotetext{
${ }^{87}$ Un buen criterio para conocer la estructura de la familia lo constituye la aparición de varios miembros de ésta obligándose en los contratos notariales, bien conjuntamente o como fiadores requeridos por el fuero.

${ }^{88} 1$ hijo*: Abram Lonieto (Jamila).

2 hijos: Açach Abambron (Barjala y Bonafos); Jacob Abambron (Mosse y Fahim); Baruch Almosnin $(+)$ (Azerian y Salamon); Azerian Almosnin $(+)$ (Sento y Salamon); Menahem Ampifaz (Sol y Salbuenya); Jacob Avingoyos (+) (Azerian y Açach); David Avingoyos (+) (Sorbellita y Miriam); Jacob Avingoyos (Açach y Azerian); Bonafos Gallipapa (Abram y Juce). Fahim).

3 hijos: Saçon Alcala (+) (Barjala, Mahir y Açach); Jahuda Abambron (Oro, Faranel y

$*$ [Colocamos entre paréntesis los descendientes] Cfr. Apéndice. Responsa rabínicos de los judíos de Jaca.

${ }^{89}$ Motis, Los judios de Jaca en el siglo XV, op. cit.
} 
cuñadas, así como otros miembros parentales de la misma generación ${ }^{90}$. El sistema de herencia liga fuerte y solidariamente a estas familias extensas patriarcales en una sociedad cuyo ritmo de crecimiento no permite a los hijos vivir al margen de las explotaciones familiares hasta que el matrimonio - dote - y la muerte o envejecimiento de los padres - herencia, donación inter vivos- les convierte en directores de una unidad productiva ${ }^{91}$. Los hermanos colaboran frecuentemente en los negocios bajo la autoridad del padre o quizás bajo la preeminencia del hermano mayor.

Aunque cada unidad familiar posee su propia casa - no conviven los hermanos y los padres en el mismo hogar- es posible afirmar que sí viven bajo el mismo techo, puesto que las casas se dividen y subdividen para que los familiares más próximos sigan siendo vecinos ${ }^{92}$. En Jaca, por otro lado, la institución de la casa llega a primar sobre la misma familia ${ }^{93}$. La familia doméstica y la extensa gira en torno al cabeza de familia, aunque los hijos y la mujer aparecen con capacidad legal subsidiaria mediante en compañía de su padre o marido- y con pleno derecho a las propiedades familiares pero sin papel directivo en los documentos de organización del patrimonio familiar.

Por último - pese a que abordaremos de nuevo el tema anterior en ulteriores capítulos de este trabajo- mencionemos las traslaciones poblacionales. Los brotes pestíferos ocasionan movimientos pendulares entre los que conocemos los que tienen como destino Ayerbe, la judería más cercana ${ }^{94}$. Lo conocemos gracias a Azerian Avengoyos, quien en nombre de su hijo, «lacrimabili» suplicaba que le fuera levantado el arresto y la fianza impuesta

\footnotetext{
${ }^{90} \mathrm{El}$ hecho de que en el fogaje de 1377 aparezcan en la lista hijos y hermanos juntos, induce a pensar que conviven con el pariente citado inmediatamente antes en la nómina, pero que forman unidad familiar aparte. ROMANO, Prorrata de contribuyentes, p. 16.

${ }^{91} \mathrm{De}$ ahí la importancia de la relación tutelar que suele correr a cargo del padre supérstite o, más comúnmente, del tío del pupilo (el hermano del difunto). Cfr. Miguel Angel Motis DOLADER, Consuetudine regni non habemus patriam potestatem. Un supuesto de tutela y curatela en la judería de Daroca en el siglo XV, "Ius Fugit. Revista Interdisciplinar de Estudios Histórico-Jurídicos", I (1992), pp. 79-138.

${ }^{92}$ Las listas fiscales jacetanas nos ofrecen incidicios de agrupación familiar, si partimos de la base de que los nombres allí enunciados se rigen por criterios de contigüidad. De este modo, los Abambron son citados entre los puestos 13-15; los Alcala 18-22; los Abengoyos 77-83 y los Almosnín 16-17, 95-96 y 103-104. ROMANO, Prorrata de contribuyentes, p. 11.

${ }^{93} \mathrm{Cfr}$. sus consecuencias sucesorias en Jesús LALINDE ABADÍA, Algunas precisiones conceptuales sobre la legítima aragonesa, "Anuario de Historia del Derecho Español", 1985, pp. $346-48$.

${ }^{94}$ Antonio DURÁn Gudiol, La judería de Huesca, Zaragoza, Guara Editorial, 1988.
} 
de 250 florines por Felipe d'Urries, motivando esa partida por la elevada mortalidad que se había declarado en Jaca ${ }^{95}$.

La documentación no nos faculta para determinar movimientos migratorios pero si nos atenemos a la onomástica podemos identificar algun efecto de atracción sobre el área cincovillesa, personalizado en Jacob Abambron, «alias Jacobet de Sos» ${ }^{96}$.

\section{CONFIGURACIÓN POLÍTICA}

La aljama se comporta como el municipio cristiano. No en vano, es una comunidad de asiento local organizada jurídico-públicamente para el cumplimiento de los fines que interesan al bien común y que goza de cierta autonomía en el marco de un poder político superior ${ }^{97}$.

\subsection{Los órganos judiciales}

Desde 1300 la corte de los beruré 'aberot ${ }^{98}$ tienen la potestad de imponer multas a los malhechores ${ }^{99}$, con jurisdicción sobre casi todos los aspectos de la vida cotidiana ${ }^{100}$. Según los responsa de Ibn Adret en esta aljama se redactó una ordenanza para castigar a todo aquel que cometiera un crimen y a tal efecto se nombraron berorim ${ }^{101}$.

\footnotetext{
${ }^{95} \mathrm{ACA}$, Cancillería, reg. 2361, fol. 17 v.

${ }^{96} \mathrm{AHPH}$, Protocolo 8666, Jaca, 1410, fol. 24.

${ }^{97}$ José M ${ }^{\text {a }}$ FONT RiUS, Orígenes del régimen municipal de Cataluña, Madrid, 1946, p. 6.

${ }^{98}$ Abraham Hershman, Rabbi Isaac ben Sheshet Perfect and his times, New York, The Jewish Theological Seminary of America, 5704-1943, pp. 115-116.

${ }^{99}$ Jean RÉGNÉ, History of the Jews in Aragon, doc. 517.

${ }^{100}$ Los beroré 'aberot de la aljama de Jaca quisieron multar a uno de sus miembros porque la nodriza judía de sus hijos había ido a lavarse al río el último día de Pascua, a través de los Responsa de R. Selomó ben Adret. El Fulano jura por la Torah que no sabía nada del asunto y que la nodriza no era natural de Jaca sino que había venido para pasar las fiestas con su hija la cual enfermó. Para su curación una curandera le recomendó "Toma aceite y sal y lava tu hija: luego arrójala al río y sanará». La mujer cogió a su hija y se metió con ella en el río para que los cristianos no sospechase que hacía magia o sortilegios al echarla al agua. Temor a que pensaran que envenenaba las aguas. Fritz BAER (Yitzhak), Historia de los judios en la Corona de Aragón (s. XIII y XIV), Zaragoza, 1985, p. 187.

${ }^{101}$ Fritz BAER (Yitzhak), Historia de los judios en la Corona de Aragón (s. XIII y XIV), p. 230, Apéndice II, $\mathrm{n}^{\circ} .31$.
} 
Cuando la aljama pasó a depender de la jurisdicción de Violante de Bar - mujer de Juan I- se incrementa la separación entre las funciones de los tribunales hebreos y cristianos, no consintiendo la ingerencia de los oficiales del primogénito y gobernador de Aragón, léase, de su marido. La población judía tenía prohibido entrar en comanda o custodia de pleitos en poder de los cristianos, bajo pena de 500 florines de oro ${ }^{102}$.

En general, la curia real se reservaba el derecho de apelación en última instancia, así como la ratificación de las sentencias emitidas por los jueces de la aljama, como sucedió en 1385 tras el prendimiento de Judá Avingoyos ${ }^{103}$. Por lo demás, no se produce un alto índice de conflictividad, registrándose casos, incluso por la vía criminal, de sobreseimientos, como sucede el 18-VII-1419, en que por acuerdo amistoso Domingo Loase y su hijo Johan, que habían acusado a Fahim Abenardut de darle un golpe a Domingo en la cabeza el día de Viernes Santo, tras la cual había dado voz de apellido ${ }^{104} \mathrm{e}$ iniciado proceso es absuelto de toda responsabilidad ${ }^{105}$.

Poseemos, igualmente, algunos indicios de gastos procesales por algún albarán suelto, como el fechado el 19-III-1416, en el que Faym Lavor y Barchala Abambron se obligan «al libro de la Cort del Justicia de Jaca assi como por sentencia passada en cosa judgada» a pagar a don Pero Pérez de Loriz, sabio en derecho, 20 florines de oro, que podrían derivar del pago de costas procesales o de la asistencia letrada en los pleitos mantenidos en aquella audiencia ${ }^{106}$.

Si bien, el mayor número de sentencias gira en torno al capítulo de los préstamos. En 1420 Alazar Avinardut obtiene una sentencia favorable al considerar lícitas sus pretensiones sobre 5 arrobas de trigo adeudadas por p. 154.

${ }^{102}$ ACA, Cancillería, reg. 1808, fols. 108 v.-109. LEDESMA, El Patrimonio real en Aragón,

El delito consistente en mantener relaciones carnales con cristianas se sitúa en uno de los primeros puestos de la escala punitiva. El hijo de Açach Almosnin, hubo de pagar 3.000 sueldos por su comercio carnal con Jordana. Jean RÉGNÉ, History of the Jews in Aragon, doc. 2788.

Otro integrante de la familia Almosnin - Abraham - es penalizado con 3.000 sueldos por cortejar a una cristiana de la ciudad. Jean RÉGNÉ, History of the Jews in Aragon, doc. 2795. p. 154 .

${ }^{103}$ ACA, Cancillería, reg. 1808, fols. 153-153 v. y LEDESMA, El Patrimonio real en Aragón,

${ }^{104}$ Luis GARCÍA DE VALDEAVELLANO, El apellido sobre el procedimiento in fraganti en el Derecho Español medieval, "Cuadernos de Historia de España", VII (1947), pp. 68-106.

${ }^{105}$ AHPH, Protocolo 8669, Jaca, 1419, fols. 98 v.-99.

${ }^{106} \mathrm{AHPH}$, Protocolo 8115, Jaca, 1416, fol. 12. 
Johan y Garcia Aznarez, habitantes en Avena ${ }^{107}$. No hemos encontrado para este período mención explícita a actuaciones judiciales del merino que a fines del siglo XIII, lo vemos actuando en actos de seguro y caución ${ }^{108}$.

\subsection{Los órganos de gobierno}

En nuestro breve repaso daremos cuenta de dos órganos colegiados de poder: la aljama y los adelantados.

\subsubsection{La aljama}

Existen una serie de asuntos que requieren el concurso de la aljama como son la suscripción de censales y el nombramiento de procuradores. Pasemos revista a las más significativas del período. No parece que se superen las dos o tres sesiones anuales. Suelen convocarse con carácter extraordinario, salvo aquéllas en las que se procede a la elección de cargos.

El 18-IV-1413, respondiendo al llamamiento efectuado por Abram Arama, samas o «bedín», dentro de la sinagoga mayor, «alli do e segund otras vegadas yes usado e costumbrado plegar e ajustarse los judios e aljama sobreditas por tractar e desembarguar los afferes e negocios de aquella ${ }^{109}$ presididos por los adelantados Maestre Abendavit y Açach Alcala y encontrándose presentes veintiuna cabezas de familia ${ }^{110}$, comune consilio procuran a Pedro Alqueçar, notario, Palazin de Villanua, Salbador de Loriz

\footnotetext{
${ }^{107}$ AHPH, Protocolo 8724, Jaca, 1420, fol. 4.

${ }^{108}$ Barzelay, hijo del difunto Açach de Maheger, había sido inculpado de cometer adulterio con una cristiana, por cuya causa todos los bienes de u hermano y de su madre Oro habían sido decomisados por el merino, que se había excedido en la amenaza de arresto. Jaime de Luch, merino, es interpelado por el soberano en 1294 para que una vez obtenidas cauciones y seguridades suficientes de la familia Maheger les restituya sus bienes. RÉGNÉ, History of the Jews in Aragon, doc. 2517.

${ }^{109} \mathrm{AHPH}$, Protocolo 8667, Jaca, 1413, fols. 44-44 v.

${ }^{110}$ Maestre Azerian Abendaguet, Açaxh Avingoyos, hijo de Azerian, rabí Mahir Almosnin, Jahuda Abambron, hijo de Barjalá, Azerian Avingoyos, hijo de Jacob, Abram Lonieto, Açach Abambron, Salamon Almosnin, Mosse Babo, Azerian Gallipapa, Juce Aldich, Davit Avingoyos alias Bananat, Mahir Alnieto, David Alcala, mayor, David Alcala, menor, Azerian Avingoyos, hijo de Sento, Sento Alcala alias Senton, Faym Lanor, Juce Bivag y Juce Larros. Testigos instrumentales: Barjala Alcala, hijo de Juce, y Simuel Lavor.
} 
y Simuel Abambron, Salamon Ampifaz y Juce Almosnin, hijo de Jahuda, judíos, revocando en sus funciones Azerian Avingoyos, hijo de Judas ${ }^{111}$.

Una sesión plenaria habida en la sinagoga mayor, el 29-VIII-1413 a convocatoria de Abram Arama, y bajo la presidencia de rabí Mayr Almosnin, Açach Avingoyos y Mosse Babo, se instruye a Azerian Avingoyos, hijo de Judas, pára que obtenga préstamos por valor de 6.000 sueldos ${ }^{112}$.

El 1-X-1414 se reune la aljama a llamamiento de Abram Arama, sanoguero, bajo la tutela de Bonafos Alcala, hijo de Juçe, y Salamon Almosnin, adelantados, los concurrentes ${ }^{113}$ designan como procuradores a Azarian Avingoyos, hijo de Jacob, Juce Aldich, Barjala Alcala, hijo de Juce, Juce Almosnin, hijo de Jahuda, ausentes, para obligarse en fianza en nombre de toda la aljama «de dreyto de riedra» y manifestar ante el rey, su primogénito, sus gobernadores y autoridades aragonesas, en defensa de Salbuenya, viudả de Menahem Ampifaz, Azarias Avingoyos, hijo de Judas, maestre Azerian Abendaguet, Açach Avingoyos, hijo de Azarian, y Jahuda Abambron, hijo de Barjala, pudiendo afianzarlos con los bienes de la comunidad $^{114}$. Los interesados aceptan el nombramiento ${ }^{115}$.

El 3-VIII-1416, Azerian Avingoyos, hijo de Judas, Mosse Babo y Simuel Ampifaz encomiendan a Juce Almosnin el papel de procurador en pleitos civiles y criminales de la aljama ${ }^{116}$.

\footnotetext{
"'AHPH, Protocolo 8667, Jaca, 1413, fol. 47.

${ }^{112}$ Asistentes Jahuda Abambron, maestre Abram Avinacaya, Bonafos Alcala, Azarian Avingoyos, hijo de Jacob, Azerian Avingoyos, hijo de Judas, Abram Elnieto, Azerian Avingoyos, hijo de Sento, Açach Alcala, Bonafos Abambron, Jacob Tardiel, Abram Alcala, Azerian Gallipapa, Jucep Papur, Salamon Ampifaz, Barchala Alcala, Simuel Alcala, Jucep Gallipapa, Sazon Alcala, Berchala Abambron, Jucep Ambinach, Faym Abambron, Jucep Avingoyos, Alazar Almosnin y Azerian Almosnin. AHPH, Protocolo 8113, Jaca, 1412, fols. 33 v. -35 .

${ }^{113}$ Maestre Azarian Abendahuet; Açach Avingoyos, hijo de Azarian; maestre Abram Abenaçaya; Menahem Avingoyos, hijo de Azarian; Abram Lonieto; Azarian Avingoyos, hijo de Judas; Judan Avingoyos mayor hijo de Azarias; rabi Abram Avinpapur; Açach Alcala, hijo de Abram, quonda; Jahuda Abambron, hijo de Barjala; Simuel Ampifaz; Azarian Almosnin; Salamon Almosnin, hermanos, hijos de Baruch; Fahim Lavor; Sento Almosnin; Azarian Gallipapa; Bonafos Gallipapa; Abram Gallipapa, hijo de Bonafos, Juce Abendavit, mayor. AHPH, Protocolo 8668, Jaca, 1414, fols. 86-86 v.

${ }^{114} \mathrm{AHPH}$, Protocolo 8668, Jaca, 1414, fols. 87-87 v.

${ }^{115}$ AHPH, Protocolo 8668, Jaca, 1414, f. 89 v.

${ }^{116} \mathrm{AHPH}$, Protocolo 8115, Jaca, 1416, fol. 38.
} 
El período analizado concluye parcialmente en el año 1419 , en la sesión plenaria del 22 de junio «por tractar e desembargar los aferes e negocios de aquella» ${ }^{117}$, en la que intervienen 25 personas $^{118}$.

\subsubsection{Los adelantados}

Las distintas intervenciones de las autoridades ejecutivas de la aljama en los asuntos comunitarios nos permite acercarnos a los rectores de la colectividad y a la esfera de poder que desarrollan. No perseguimos enunciar la ortopraxis según la legislación talmúdica, sino la realidad cotidiana contenida en unas piezas documentales por definición fragmentarias.

Uno de sus cometidos inexcusables es la ejecución de los pagos - no aparece nunca la figura del clavario por lo que entendemos que la receptoría y pagaduría se concentraba en manos de los adelantados sin llegar a la complejidad administrativa de otras aljamas ${ }^{119}$ - . Así se redimen comandas suscritas por sus antecesores ${ }^{120}$, el pago de rentas de censales ${ }^{121}$ y su amortización ${ }^{122}$.

\footnotetext{
${ }^{117}$ Tras crida del samas o «sanogero», Jacob Almosnin, se congregan en primera convocatoria: Azarian Avingoyos, hijo de Jacob, y Bienvenist Abendahuet, adelantados; y Açach Avingoyos, hijo de Azerian; Bonafos Alcala, hijo de Juce; Azarian Avingoyos, hijo de Judas; rabí Abram Avinpapur; Jahuda Abambron, hijo de Barjalá; Simuel Ampifaz; Mosse Babo; Salamon Almosnin; Açach Abambron; Açach Alcala; Barjala Alcala; Bonafos Abambron hijo de Açach; Sento Abambron; Azarian Almosnin, hijo de Salamon; Simuel Abambron Bonafos Alcala, hijo de Mahir; Fahim Abambron; Barjala Sucran \& Juce Avingoyos, hijo de Açach, quondam. AHPH, Protocolo 8669, Jaca, 1419, fols. 74.

${ }^{118} \mathrm{~A}$ la convocatoria de las aljamas acuden, por término medio, además de los adelantados, una veintena de cabezas de familia varones que parece ser el quorum estabilizado, no siendo superado ni siquiera en las reuniones del más alto valor estratégico. op. cit.

${ }^{119}$ Esto es cierto hasta e final del siglo XV. Cfr. Motis, Los judios de Jaca en el siglo XV,

${ }^{120} \mathrm{El} 17$ de septiembre de 1410 , Martin d'Arco, habitante en Jaca, procurador de mosen Martin de Pomar, capitán de la ciudad de Huesca, recibe de los adelantados del ejercicio presente - maestre Abram Abenacaya, Azerian Avingoyos, hijo de Jacob y Açach Abambron60 florines de oro que adeudaban a Johan Fornero, mercader de Huesca, de una comanda suscrita el 28 de abril de 1409, la cual fue transferida a su principal el 8 de junio. AHPH, Protocolo 8666 , Jaca, 1410, fols. 59-59 v.

Los adelantados Bonaffos Alcala, hijo de Juce, y Salamon Almosnin comparecen el 28 de septiembre de 1413 en el pago de una comanda de 1.100 sueldos. AHPH, Protocolo 8667, Jaca, 1413, fol. 96 .

${ }^{121}$ AHPH, Protocolo 8667, Jaca, 1413, fols. 16 v.-17.

${ }^{122}$ AHPH, Protocolo 8667, Jaca, 1413, fol. 94 y Protocolo 8668, Jaca, 1414, fol. 76.

El 16 de marzo de 1419 , por idéntico motivo, se dan cita Judas Avingoyos, mayor, rabí Abram Avinpapur y Salamon Almosnin. AHPH, Protocolo 8669, Jaca, 1419, fols. 54 v.-55.
} 
Los adelantados se hallan imbricados orgánicamente con las cofradías de ayuda mutua, debiendo prestar su anuencia en la enajenación patrimonial de la almosna, como la realizada el 14-III-1413, con la presencia del rabí Mayr Almosnin, Açach Avingoyos y Mosse Babo, que asisten a la compraventa de una viña por valor de 70 florines ${ }^{123}$. En épocas pretéritas los adelantados eran los interlocutores de los que se servía la Corona para negociar la cuota tributaria ${ }^{124}$.

En un acto público celebrado el 20-III-1419 comparecen rabí Abram Abinpapur y Salamo Almosnin con motivo de las obras de mejoras e infraestructura practicadas en los baños judíos para evitar que causen daños a terceros las aguas residuales ${ }^{125}$. Por su parte, Bienvenist Abendahuet y Salamon Ampifaz, asisten a una renuncia de franqueza, demostrándose una vez más que no era imperiosa la presencia plenaria del triunvitaro, sino que bastaba con la mayoría de los $2 / 3$, en los asuntos no sustantivos ${ }^{126}$. Azarian Avingoyos, Bienvenist Abendahuet y Salamon Ampifaz siguen ejerciendo tal poder el 27-XI-1419 cuando son apercibidos de embargo si no satisfacían 100 florines adeudados con el representante de las aljamas del reino Vidal de la Cavalleria ${ }^{127}$.

En enero de 1413 los adelantados rabí Mahir y Mosse Babo, convocan a Azerian Avingoyos, hijo de Jacob, a propósito de cierta taza de plata que tenía empeñada a Açach Avingoyos, hijo de Azerian ${ }^{128}$. Es decir entienden en los préstamos intracomunitarios.

El 19-II-1413, convocan en la sinagoga a Judas Avingoyos, hijo de Azerian, heredero de Bitas «sobre cierta yeta ${ }^{129}$ " que le hacían los adelantados y secretarios de la aljama. Posiblemente se refiere a los impuestos de sucesiones ${ }^{130}$.

\footnotetext{
Actúan como pagadores los adelantados Azarias Avingoyos, hijo de Judas, quondam y maestre Juce Abendavit. AHPH, Protocolo 8668, Jaca, 1414, fols. 15 v.-16.

${ }^{123}$ AHPH, Protocolo 8720, Jaca, 1413, fols. 9-9 v.

${ }^{124}$ RÉGNÉ, History of the Jews in Aragon, docs. 1187 y 1284.

${ }^{125}$ AHPH, Protocolo 8669, Jaca, 1419, fol. 57.

${ }^{126} \mathrm{AHPH}$, Protocolo 8669, Jaca, 1419, fols. 112-113.

${ }^{127}$ AHPH, Protocolo 8669, Jaca, 1419, fols. 169-171.

${ }^{128} \mathrm{AHPH}$, Protocolo 8667, Jaca, 1413, hoja suelta entre fols. 27-28

${ }^{129}$ Sinónimo de talla, tallia o geta.

${ }^{130} \mathrm{AHPH}$, Protocolo 8667, Jaca, 1413, fol. 30 v.
} 
Si tuviéramos que sintetizar los poderes y prerrogativas de los adelantados derivándolas de las actuaciones precedentes, podríamos argumentar que representan legalmente los poderes aljamales en toda actuación pública que afecta a su patrimonio; efectúan los pagos ${ }^{131}$; presiden y convocan las reuniones de la aljama fijando el orden del día de los consejos; entienden y arbitran en préstamos entre judíos y en derechos sucesorios. En contraprestación al cargo ostentado han de responder con sus bienes de los compromisos económicos y las deudas que pesan sobre la aljama. Existen, por otro lado, actuaciones de inhabilitación en cargos de interés público como el desempeño del sacrificio cárnico ${ }^{132}$

Pero sus prerrogativas no acaban ahí. Los adelantados tienen potestad para intervenir en el derecho de familia, pudiendo llegar a vetar ciertos contratos matrimoniales. La sesión celebrada el 4-V-1413, los adelantados Juce Abendavid y Açach Alcala, exponen que dado que Azerian Avingoyos, hijo de Judas, "havies casado su filla con Benvenis, judio francho, et iuxta el privilegio que metian e metieron pena alalma e niduy de no intervenir en el dito matrimonio etc. et pena del privilegio de la senyora reyna». Este enlace matrimonial no contaba con la aprobación del dicho Bonafos y Barchala Alcala, hijo de Juce ${ }^{133}$. El 11-IV-1414 seguía bajo suspensión y las penas permanecían vigentes - «metido alalma e nidduy e otras penas»- contra todo aquel que roborara los capítulos matrimoniales de Benvenist de la Cavallería, judío franco, y Ceti, su hermana, con Sol, mujer suya, hija de Azerian Avingoyos, hijo de Judas. Los rectores comunitarios sólo desistirán en su actitud cuando Bienvenist, por medio de una letra cursada por la reina doña Yolanda el 12-V-1413, renuncie a su exención fiscal y franquicia ${ }^{134}$.

El ejercicio de su mandato es anual. El sistema electivo en vigor sigue siendo la cooptación, cuya primera autorización conocida data del año 1285 en que Pedro III autoriza a los adelantados con el mandato a punto de expirar a que elijan a los sucesores del año próximo, según la costumbre lo

\footnotetext{
${ }^{131}$ No así la suscripción de deuda pública aunque quizás sí intervienaran en las negociaciones preliminares previo conocimiento de los representantes de las tres manos.

${ }^{132}$ RÉGNÉ, History of the Jews in Aragon, doc. 1438.

${ }^{133} \mathrm{AHPH}$, Protocolo 8720, Jaca, 1413, fols. 9-9 v.

${ }^{134} \mathrm{AHPH}$, Protocolo 8114, Jaca, 1414, fol. 23.
} 
que nos faculta para pensar en que es una práctica consuetudinaria antigua $^{135}$. La carta se fecha el 27 de agosto por lo que es dado pensar que el turno en el ejercicio del poder se lleva a cabo en el mes de septiembre aunque, en ocasiones, como sucede en 1419 , éste comienza a ser ejercido en junio.

De los datos que obran en nuestro poder, podemos identificar el mandato de alguno de estos dirigentes:

1409-10: Bonafos Alcala, hijo de Juce; Azerian Abendahuet y Azerian Avingoyos, hijo de Judas

1410-11: Abram Abenacaya, Azerian Avingoyos, hijo de Jacob, y Açach Abambron.

1412-13: Mayr Almosnin, Açach Avingoys, hijo de Azerian y Mosse Babo.

1413-14: Azerian Avingoyos, hijo de Judas, Juce Abendavit, y Açach Alcala.

1414-15: Bonafos Alcala, hijo de Juce, Salamon almosnin y [...].

1416-17: Azerian Avingoyos, hijo de Judas, Mosse Babo y Simuel Ampifaz.

1418-19: Judas Avingoyos, mayor, Salamon Almosnin y Abram Abinpapur.

1419-20: Azarian Avingoyos, hijo de Jacob, Bienvenist Abendahuet y Salamon Ampifaz.

\subsection{El notariado}

La aljama se encuentra desarrollada a nivel administrativo y cuenta con un registro notarial propio aunque por largos años la escribanía estuviera encomendada, como durante el siglo XIII, a cristianos ${ }^{136}$.

\footnotetext{
${ }^{135}$ RÉGNÉ, History of the Jews in Aragon, doc. 1438.

${ }^{136}$ En 1281 Pedro III concede a P. Pons, notario de Jaca, durante cinco años a contar desde la festividad de San Juan, la redacción de las actas públicas de los judíos, con un cargo anual de 6 morabetinos de oro pagaderos al baile del lugar RÉGNÉ, History of the Jews in Aragon, doc. 867.

El poseedor de esta licencia debió llevarla a cabo con gran escrupulosidad ya que meses después el monarca es informado de que no se autoriza a los judíos a formalizar sus instrumentos públicos más que por él, por lo que se instruye al justicia y al baile para que permitan que acudan a cualquier escribano que estimen oportuno. RÉGNÉ, History of the Jews in Aragon, doc. 1179.
} 
En los protocolos cristianos se mencionan testificaciones judiegas como la habida el 20 del mes de Senach del año 5.173 de la Creación del mundo, nombrando tutores de Juce, hijo de rabí Juce Abendavit, a Bonafos Alcala, hijo de Juce, y maestre Juce Abendavit, testificada por maestre Azerian Abendaguet, notario ${ }^{137}$. A este podríamos añadir la carta pública levantada el 13 de Elul de 5.173, testificada por Juce Almosnin, hijo de Jahuda, con motivo de la hipoteca que Dueña, viuda de Faym Almosnin, había efectuado por 500 sueldos a Salamon Almosnin sobre unas casas y huerto de su propiedad ${ }^{138}$

Simultáneamente en Jaca están trabajando dos profesionales, en sintonía con la importancia de la aljama, lo que da clara idea de la cantidad de información interna que se ha perdido.

\section{LA ARTICULACION SOCIAL}

Si atendemos a los resultados obtenidos por D. Romano en el estudio de la prorrata de 1377 , donde ensaya una división de la sociedad en tres manos, atendiendo a su capacidad contributiva, obtendríamos algunos datos objetivos que permanecen en vigor un cuarto de siglo más tarde.

Partiendo de sus postulados, la mano mayor estaría representada por aquellos individuos que tributaran más de 25 sueldos; la mano mediana los que abonan entre 4 y 25 sueldos, mientras que la menor se nutriría de los que no alcanzan los 3 sueldos 9 dineros. De este modo, de los 115 contribuyentes nominados, 10 personas corresponderían al estrato superior, 24 al medio y 81 al inferior. Los valores porcentuales se aprecian en el diagrama que sigue:

\footnotetext{
${ }^{137}$ AHPH, Protocolo 8 667, Jaca, 1413, fol. 41 v.

${ }^{138} \mathrm{AHPH}$, Protocolo 8 667, Jaca, 1413, fol. 62..
} 


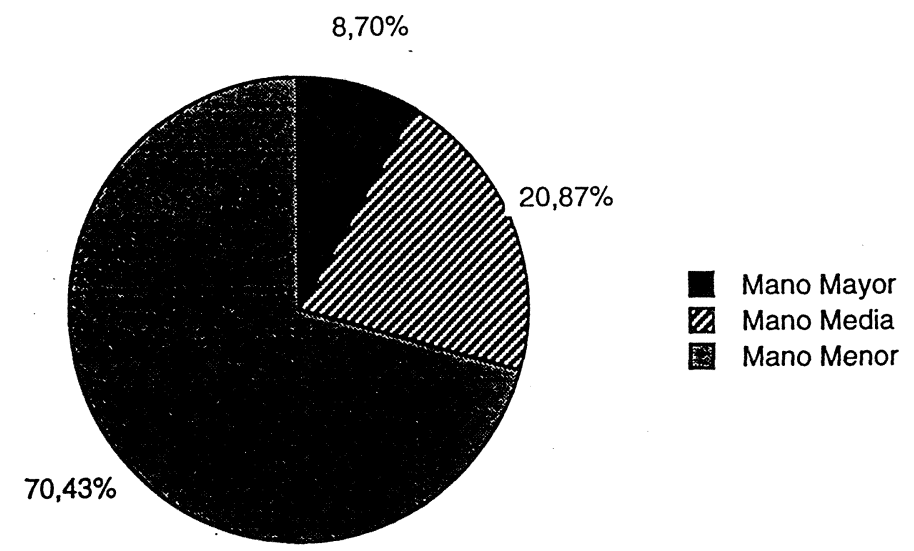

Gráfico 1: Los estratos socio-económicos de la aljama de Jaca

Si la tasa liquidatoria es traducción de un patrimonio mobiliario, inmobiliario y monetario dado, la riqueza acreditada por sus habitantes se establecería del modo siguiente:

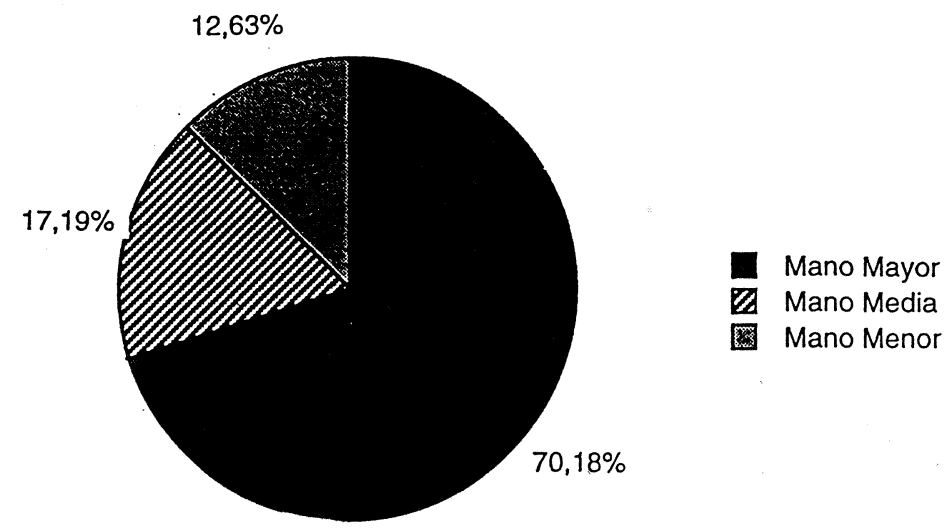

Gráfico 2: Distribución de la riqueza según la prorrata de 1377

Los contrastes sociales son tan obvios que basta con una lectura superficial para percibir que mientras que los efectivos de la mano mayor significan el $8,7 \%$, ostentan un $70,18 \%$ de la riqueza. La proporción se invierte al hablar de la menor pues sus miembros alcanzan numéricamente 
un 70,43 (casi el mismo porcentaje que los bienes poseídos por los más ricos) pero económicamente su peso se reduce a un $12,63 \%$. Resulta evidente que estos abismos ni son patrimonio de la judería jacetana ni mucho menos de los judíos respecto a los mudéjares o cristianos de otras poblaciones aragonesas.

Adviértase, por otro lado, la delgadez de la clase media que tanto en poder adquisitivo como en integrantes gira en torno al $20 \%$. Ello explica, quizás mucho mejor que cualquier otra reflexión, las convulsiones e inestabilidades internas producidas a la hora de escoger un procedimiento exactivo u otro y la debilidad estructural de la aljama en época de crisis financiera o comercial por la ausencia relativa de una robusta y poderosa clase media artesanal con posibilidad de capitalización a través de la comercialización de sus productos, reinvertida en pequeños préstamos o en adquisición de bienes raíces.

Como en todas las sociedades los grupos más desprotegidos -además de los desposeídos de la fortuna y menesterosos- son los huérfanos y las viudas. De éstas últimas tenemos constancia de disminuciones patrimoniales con el fin de obtener dinero líquido tras el fallecimiento del marido, presunto mantenedor de la economía doméstica ${ }^{139}$.

El estatuto de judíos francos como clase diferenciada de los pecheros no existe como tal en Jaca, como sí sucede en Zaragoza o Calatayud ${ }^{140}$. Los contados casos de gentes con esta condición privilegiada son forasteros que, al afincarse en la ciudad, han de abjurar inmediatamente de este fuero. Uno de estos supuestos es el atravesado por Alazar Abenardut, el 21-VIII1419 , quien, pese a su franquicia, declara que, entendiendo que ha decidido fijar su residencia en la ciudad, ha de pechar "segund que un judio e otro de la aljama sobredita yes tenido e deve peytar e contribuir renuncia a la dita su franqueza"141.

Las familias más ricas llevan a cabo una inteligente política marital. El linaje posiblemente más acaudalado de la ciudad, los Avingoyos, entrocan con otras familias de enorme poderío financiero como los Ampifaz ${ }^{142}$ y los

\footnotetext{
${ }^{139}$ AHPH, Protocolo 8116, Jaca, 1417, fol. 7 y Protocolo 8667, Jaca, 1413, fol. 62.

${ }^{140}$ Miguel Ángel Motis Dolader, Los judios en el reino de Aragón en la Edad Media (siglos XIII-XV), pp. 119-121.

${ }^{141} \mathrm{AHPH}$, Protocolo 8669, Jaca, 1419, fols. 112-113. Ampifaz.

${ }^{142}$ Ceti Ampifaz es viuda de Judas Avingoyos y Falbuenya Avingoyos lo es de Menahem
} 
Almosnin ${ }^{143}$ con lo que se incrementa, más aún si cabe, el peso específico anterior a estos enlaces ${ }^{144}$.

A fines del siglo XIV, de acuerdo con la tantas veces citada prorrata de 1377, existen, cuatro linajes capitales en la aljama tanto por su peso económico como por su ascendiente socio-político ${ }^{145}$. Por un lado, si atendemos a la tasa tributaria abonada, están los Avingoyos, cuyos doce miembros tabulados contribuyen con 404 sueldos, lo que se traduce en un promedio de 33 sueldos 8 dineros ${ }^{146}$. Los trece individuos de la familia Abanbrón tributan un total de 147 sueldos, es decir, 11 sueldos 4 dineros de media $^{147}$.

Muy por debajo de estos guarismos se encuentran los Almosnin que, con sus 69 sueldos 6 dineros, se situarían en nivel de 5 sueldos 9 dine$\operatorname{ros}^{148}$. Los Alcala, cuyos quince componentes censados no alcanzan más que los 63 sueldos 6 dineros o, lo que es lo mismo, 4 sueldos 3 dineros. Es evidente, como constataremos en las paginas siguientes que los que portan el mismo apellido no registran un mismo nivel económico ${ }^{149}$.

La sociedad no es igualitaria, mostrando grandes desequilibrios. En este contexto, las agrupaciones filantrópicas de ayuda mutua ponen en marcha uno de los mecanismos creados por la sociedad para paliar los desajustes mencionados. En Jaca recibe el nombre de «almosna», similar a

\footnotetext{
${ }^{143}$ Aroça Almosnin está casada con David Avingoyos; Salamon Avingoyos con Astruga Almosnin y Jamila Almosnin con Azerian Avingoyos.

${ }^{144}$ Es una práctica universal maridar en el seno del mismo grupo social o en el inmediatamente superior como vehículo de ascenso económico y estatutario. Esto puede conducir, llegado el caso, a un alto grado de exogamia con judíos de poblaciones vecinas, en la búsqueda de un esposo o esposa homóloga. Por ejemplo, en Salon-de-Provence, un 80,75\% se formaliza con judíos no autóctonos. Monique WERNHAM, Stratégies matrimoniales des Juifs de Salon-de-Provence (1396-1435), "La famille juive au Moyen Age, Provence Historique", XXXVII (1987), p. 494.

${ }^{145}$ La situación de los linajes más poderosos, que no experimentan cambios apreciables en el cuarto de siglo transcurrido, y sus intervenciones políticas son analizadas a lo largo de todo este trabajo.

${ }^{146} \mathrm{Si}$ bien es verdad que aportación de don Azerian Avingoyos en sí misma supone 176 sueldos 8 dineros, con lo que dicho promedio se rebajaría a 20 sueldos 8 dineros.

${ }^{147}$ Dos de sus más adinerados representantes, don Davit y su yerno, pagan entre ambos 144 sueldos 8 dineros. Si fueran excluidos de nuestros cálculos, el reparto equitativo de impuestos se situarúa en 37 sueldos 5 dineros.

${ }^{148}$ Romano, Prorrata de contribuyentes, p. 25.

${ }^{149}$ Romano, Prorrata de contribuyentes, pp. 25-26.
} 
la del higdes bilbilitana ${ }^{150}$, aunque algunos gremios, como el de zapateros, disponga de una infraestructura asistencial autónoma. Esta limosnería cuenta con patrimonio propio ${ }^{151}$ amasado con los legados píos testamentarios y las donaciones de gentes acomodadas de la judería, sin olvidar la práctica habitual de la limosna, preceptiva entre los judíos, ejercida los viernes poco antes de la entrada del Sabbath.

Los bienes inmuebles rústicos y urbanos propios son cedidos en régimen de arrendamiento o enajenados, para obtener unos ingresos que ayuden a mantener a la institución. En la judería cuentan con algún edificio, como se pone de manifiesto en la donación de unas casas que Pero Sparça, sastre, y su hijo Leonart efectúan a Eçer, judía, madre y abuela de los anteriores, entre cuyas confrontaciones se citan unas «casas de la almosna» ${ }^{152}$. Estos inmuebles han de entenderse no como razón social sino como una de sus propiedades raíces, pues sus dependencias se encontrarían anejas a la sinagoga mayor por la función de utilidad pública que desarrollaban.

Uno de los contratos de arrendamiento emitido es protagonizado por sus rectores, Azarian Avingoyos, hijo de Judas, Azarian Avingoyos hijo de Sento, y Barjala Alcala, hijo de Juce, el 14-XI-1413 en que atreudan un «plantero» en Campienzán, a Johan y Garcia de Bergossa, vecinos de Jaca, gravándola con un censo de 8 sueldos $^{153}$ pagaderos en Todos los San$\operatorname{tos}^{154}$.

Este mismo año, para captar capital financiero, maestre Azerian Avindauch, físico, y Bonafos Alcala, hijo de Juce, almosneros, el 14 de marzo venden por 70 florines a Palazin de Villanua y María su mujer, vecinos de Jaca, una viña en la Val Primera del Obispo ${ }^{155}$. Unos meses más tarde, el 19 de diciembre, Azerian Avingoyos, hijo de Sento, y Barchala

\footnotetext{
${ }^{150}$ En esta ciudad tiene su sede en la sinagoga mayor. Miguel Ángel Motis DOLADER y María Teresa AINAGA ANDRÉs, Patrimonio urbanístico aljamal de la judería de Tarazona (Zaragoza): las sinagogas, la necrópolis y las carnicerías, "Revista de Historia Jerónimo Zurita", 56 (1987), doc. 2.

${ }^{151}$ Del mismo modo que se documenta por ejemplo las limosnerías de Magallón, Borja o Tarazona [Motis, Judíos y judeoconversos de la Raya Occidental, op. cit.] y Zaragoza [BLASCO, Instituciones sociorreligiosas judías de Zaragoza, op. cit.]

${ }^{152}$ AHPH, Protocolo 8669, Jaca, 1419, fols. 2 v.-3.

${ }^{153} \mathrm{AHPH}$, Protocolo 8667, Jaca, 1413, fol. $80 \mathrm{v}$.

${ }^{154} \mathrm{El} 29$ de diciembre reciben el primer plazo actuando como recaudaor Barjala Alcala, hijo de Juce. AHPH, Protocolo 8668 , Jaca, 1414, fol. 3.

${ }^{155} \mathrm{AHPH}$, Protocolo 8720, Pedro Alquézar, fols. 9-9 v.
} 
Alcala, hijo de Juce, venden por 36 florines de oro, a Durant de Padules, clérigo, habitante en Jaca, una viña en Carpuey ${ }^{156}$.

Los cargos rectores de esta agrupación suelen estar ocupados por tres personas que ejercen funciones análogas a los adelantados. En el segundo semestre de1413 documentamos a Azarian Avingoyos - hijo de JudasAzarian Avingoyos - hijo de Sento- y Barjala Alcala - hijo de Juce- ${ }^{157}$, mientras que en el primer semestre actúan Azerian Avindauch, físico, Bonafos Alcala, hijo de Juce Alcala. El período de su mandato no coincide con los años naturales.

Por último dejemos constancia de la cofradía de Cabbarím -Qevarim - o de enterrar los muertos, que adquirirá un mayor protagonismo económico en la segunda mitad del siglo y de la que nos ha llegado el inventario de su biblioteca compuesta por unos cincuenta y dos volúmenes ${ }^{158}$. Su magnitud parece hallarse my próxima a los depósitos de la cofradía de Borja que contaba, a fines del siglo XV, con cuarenta y cinco libros valorados en 4.000 sueldos $^{159}$.

\section{HACIENDA Y FINANZAS}

La aljama, como las corporaciones civiles cristianas, disponen de un sistema propio de recaudación de fondos para hacer frente a las demandas externas e internas que garanticen su supervivencia como colectivo ${ }^{160}$.

\subsection{Sistema tributario}

Asistimos a un momento álgido en lo referido al procedimiento fiscal, según se desprende de lo manifestado en una carta remitida entre 1391

\footnotetext{
${ }^{156}$ AHPH, Protocolo 8720, Pedro Alquézar, fols. 65 v. -66.

${ }^{157} \mathrm{AHPH}$, Protocolo 8667, Jaca, 1413, fol. $80 \mathrm{v}$.

${ }^{158}$ Eleazar GUTwIRTH y Miguel Ángel MOTIS DOLADER, Twenty-six Jewish Libraries from Fifteenth-Century Spain, "The Library", 18 (1996), pp. 43-45.

${ }^{159}$ Miguel Ángel Motis Dolader, Documentos sobre los judios de Borja (1455-1500), Zaragoza, Anúbar Ediciones, 1988, doc. 321.

${ }^{160}$ Miguel Ángel Motis Dolader, La sociedad judía aragonesa en la Edad Media, "Historia Social de Aragón. II. Economía y Sociedad", Institución Fernando el Católico, Zaragoza, 1996, pp. 347-62.
} 
y 1410, por el secretario de la aljama de Zaragoza, Selomó de Piera, a la comunidad de Teruel $^{161}$, a propósito de ciertas diferencias que estallaron sobre la modalidad del reparto de los impuestos ${ }^{162}$. En ella evoca los conflictos similares que rebrotaron en Jaca por motivos análogos; al parecer, se habían decantado en primer término por la declaración personal jurada pero se percataron de inmediato de cuán susceptible de defraudación ${ }^{163}$ era, dejándose influir por la de Zaragoza que había renunciado a esa vía al igual que Huesca en $1389^{164}$.

Entendemos que se refiere a las reformas administrativas emprendidas en 1382 donde, a más de encomendar a los clavarios la administración de gastos e ingresos de la aljama, introducía nuevas garantías como la intervención de los oidores de cuentas y la nominación de tres tasadores, en

\footnotetext{
${ }^{161}$ Fritz (Yitzhak) BAER, Historia de los judios en la Corona de Aragón (s. XIII y XIV), pp. 216-217.

${ }^{162}$ Casi un siglo antes, en 1284 , Pedro III había redoblado sus esfuerzos por racionalizar una normativa fiscal coherente, para lo cual solicitó que la aljama de Jaca -entre otras muchasdesignara dos o tres delegados que aportaran sus libros de caja y escrituras relativos a las tallas, colectas y exacciones de los últimos quince años, para rendir cuentas de las pechas, tributos, servicios, cenas y otras exacciones percibidas por el fisco real, después de que Jaime I fijara la tasa máxima de interés. Además debían hacerle llegar una nómina con los sujetos pasivos pecheros - así como los francos-y sus tributaciones o tasas a tenor de su patrimonio mueble e inmueble, ajuares y enseres domésticos. Todo ello irá complementado recaudaciones, alatmas, tallas, cartas y prestación de juramentos. Los delegados entregarán las actas donde se consignen en las taccanôt, las declaraciones de alatma destinadas a la percepción de impuestos, estatutos anuales hechos por los adelantados, bandos y ordenanzas promulgadas para la represión de estos delitos, los registros de los juicios civiles y criminales, los privilegios que reconozcan sus derechos judiciales y la detección de posibles irregularidades y fraudes habidos en perjuicio del rey o de los menores. RÉGNÉ, History of the Jews in Aragon, doc. 1172.

Sobre otros problemas derivados del sistema fiscal. vid. RÉGNÉ, History of the Jews in Aragon, doc. 1344, 1362 y 1370.

${ }^{163}$ Entre $1310-1313$ se sustancian algunas causas ante el baile por motivos ficales. Entre otras sentencias se condena a Mayl Almosnin a causa de que en un albarán de don Salamon Abencrespo sobre la estimación de sus bienes era «errado y fallido», ya que en un deudo sobre el concejo de Javierreguay -en el que habíam cobrado 60.000 sueldos- había declarado 10.000. Esta falsedad en documento público que entrañaba fraude fiscal, se zanja con una multa de 350 sueldos, en evicción de pleito que, a buen seguro, hubiera resultado más gravoso para las partes. La detracción de 15 sueldos para el acusador pone de manifiesto la licitud de la delación y la actuación del ministerio fiscal a instancia de parte en un delito grave como éste en que se lesionan los intereses de toda la sociedad. Al denunciante le corresponde una compensación económica que se sitúa en torno al $4 \%$ de la multa a pagar por el acusado. Fritz BAER, Die Juden im Christlichen Spanien. Erster Teil. Urkunden und Regesten. I. Aragonien und Navarra, doc. 342
}

${ }^{164}$ Miguel Ángel MOTIS DOLADER, Ordinaciones de la alcabala de la aljama judía de Huesca del año 1389, Anubar Ediciones, Zaragoza, 1990 y Régimen fiscal de las comunidades judías de Aragón en la Baja Edad Media: la aljama de Huesca en el siglo XIV, "Homenaje a Alfonso García Gallo", Madrid, 1995, pp. 489-580. 
representación paritaria de los tres estamentos socio-económicos ${ }^{165}$. Lo cierto es que la aljama más importante del reino se vio sumida en continuos y quebrantadores movimientos pendulares que, según presionaran los mayores o menores de la aljama, se decantaba por la declaración jurada o la tasación, cuyos primeros conatos estallaron hacia $1311^{166}$.

El debate había comenzado a gestarse en Jaca en el último tercio del siglo XIV, motivando una seria advertencia de la infantisa doña Violante a los adelantados y los doce secretarios de los negocios de la aljama respecto a la discordia, todavía no acallada, sobre las imposiciones u ordinaciones de la talla que habían de abonar los mayores de 18 años y los hijos emanciados aunque no contaran con esta edad -tasada en 220 florines de oro-, concediéndoles un plazo de 15 días para que arbitrasen el sistema. Para ello, si fuera menester, debían recluirse en una habitación hasta alcanzar la unanimidad. Si no eran capaces de lograrlo en la moratoria dispensada enviaría como mediador a Alazar Golluf, procurador general en el reino de Aragón, para dictar un laudo arbitral de obligado cumplimiento ${ }^{167}$.

En 1377 se realizará en Jaca la «taxacion siquiere ordinacion de peyta»e la que se incluye el «cobeçage [y la] taxacion de bienes mobles e sedientes ${ }^{168}$, realizada por Joan Elias de Epila, notario de la despensería del infante Juan a quien el rey había asignado todas las rentas de la ciudad, según comisión otorgada el 7-III-1377, con una vigencia prevista de un año -que sería prorrogada al menos un quinquenio-. Se considera susceptible de tributar a todo aquél que constituyera una célula económica independiente $o$, lo que es lo mismo, desempeñar un oficio y/o haber contraído matrimonio.

Evidentemente, uno de los recursos principales en los que sustenta la eficacia económica de la aljama se funda en los impuestos directos sobre sus administrados. La situación de alguno de los sujetos pasivos llega a tal extremo que se vieron obligados a poner en el mercado una porción de su patrimonio para afrontar las deudas tributarias. Este es el lance contemplado en un documento fechado el 23-II-1419 en que Duenya, viuda de Fahim

\footnotetext{
${ }^{165}$ Fritz BAER, Die Juden im Christlichen Spanien, doc. 342.

${ }^{166}$ María Asunción BlASCO, Los judios de Zaragoza en el siglo XIV: su evolución social, "Minorités et marginaux en Espagne et dans le Midi de la France (VII'-XVIII ${ }^{\mathrm{e}}$ siècles)", Paris, CNRS, 1986, pp. 186-188.

${ }^{167}$ Fritz BAER, Die Juden im Christlichen Spanien, doc. 364.

${ }^{168}$ Romano, Prorrata de contribuyentes, pp. 30-36.
} 
Almosnin, y el matrimonio compuesto por Abram Abenaçaya, físico, y Jamila «actendientes nos e cada uno de nos seyer oppresos e benidos a grant necesidat pora pagar nuestra part e de cadauno de nos en la aljama de las vendas ordinarias e extraordinarias devidas al senyor rey e a la senyora dona Yoland e otras cargas muytas» ${ }^{169}$.

Tras conseguir licencia de doña Violante en Peñalba, el 23 de mayo de 1410, enajenan una viña en Carpuey, limítrofe con otra viña de Menahem Ampifaz, viña de San Francisco, el barranco y una carrera pública, incluyendo las rasas, árboles frutales etc. Se tasan en 160 florines de oro pagados por Martin y Johan de Rayça, notario, hijo suyo, ciudadanos de Jaca. Entendemos que la cantidad adeudada era considerable pues sino no se explica una operación de esta envergadura ${ }^{170}$.

La coyuntura económica de muchas economías domésticas debía ser muy apurada y extrema al verse en la precisión de enajenaciones patrimoniales para satisfacer unàs cargas aljamales cuyo cobro resultaba de importancia mayúscula e imperiosa ya que, de otro modo, dudamos que los rectores de la aljama forzaran a esta actuación a sus tutelados no sin antes concederles prórrogas u otros medios de pago alternativos.

La residencia en la aljama imponía su contribución a los gastos generales pues, en teoría, se beneficiaban de sus prestaciones y servicios. En un acto solidario - presidido por los adelantados Bienvenist Abendahuet y Salamon Ampifaz-, registrado el 21 de agosto de 1419 Alazar Abenardut, manifiesta «que como el e los suyos de jamas aqua fuesen e sian francos e el de present fiziesse e faga su habitacion e entienda fazer continua en la ciuda de Jacca queriendo contribuir e peytar segund que un judio e otro de la aljama sobredita yes tenido e deve peytar e contribuir... renuncia a la dita su franqueza ${ }^{171}$. Decimos solidario pues su estatuto le hubiera permitido inhibirse de cualquier prestación económica a las arcas aljamales.

\subsubsection{Emisión de deuda pública}

La aljama, cuando los ingresos corrientes son insuficientes, ha de recurrir a la emisión de deuda pública a corto, medio o largo plazo, a través

\footnotetext{
${ }^{169}$ AHPH, Protocolo 8669, Jaca, 1419, fols. 41-43.

${ }^{170}$ Ibidem.

${ }^{171}$ AHPH, Protocolo 8669, Jaca, 1419, fols. 112-113.
} 
de censos enfitéuticos o comandas. Aun cuando no se observa un grado tan preocupante de endeudamiento como a mediados del siglo, que les obligará a sucesivas renegociaciones de la deuda para eludir una suspensión de pagos, si comienza la espiral que la motivará.

a) Deuda a corto plazo: las comandas.

El depósito comanditario se oferta en el mercado cuando existe el deseo de zanjar la deuda contraída con cierta rapidez aunque estimamos que este sistema era más gravoso por adecuarse a los mecanismos de la oferta y la demanda y pesar un interés menos llevadero que los censales, mucho más estables en sus tipos ${ }^{172}$.

De las acaecidas en este período tenemos constancia de la suscrita el 28-IV-1409 con el mercader oscense, Johan Fornero, por un nominal de 60 florines de oro, la cual fue transferida el 8 de junio de ese año a mosen Martin de Pomar, capitán de la ciudad de Huesca, quien la hace efectiva el 17-IX-1410 ${ }^{173}$, es decir, a 15 meses de amortización. La captación de capitales en la plaza oscense se debe quizás a que son más ventajosos, a su situación latente de insolvencia que detraía a cualquier acreedor local, o a la imposibilidad de que la generación autóctona de capitales no fuera bastante como satisfacer la demanda ${ }^{174}$.

En ocasiones han de sustentarla los más ricos, ejerciendo como fiduciarios de la aljama. Así, el 28-IX-1413, Aznar de Petraner, vecino de Echo, recibe de los adelantados 1.100 sueldos de una comanda que suscribieron Menahem Ampifaz, maestre Abram Abenacaya, físico, Açach Avingoyos, hijo de Azerian, rabí Mahir Almosnin, Azarian Avingoyos, hijo de Sento, Azarian Avingoyos, hijo de Judas, Bonafos Alcala, hijo de Juce, Bonafos Ampifaz, Mosse Babo, Baruch Almosnin y Açach Alcala, hijo de Abram $^{175}$. El empréstito se había producido el 18-VII-1407.

\footnotetext{
${ }^{172}$ Miguel Ángel Motis Dolader, Los judíos zaragozanos en la época de Fernando II de Aragón, «Minorités et marginaux en Espagne et dans le Midi de la France (VII-XVIII siècles)», pp. $385-412$.

${ }^{173}$ AHPH, Protocolo 8666, Jaca, 1410, fols. 59-59 v.

${ }^{174}$ Manuel GómeZ DE VALenZuela, La actividad mercantil de los judios de Jaca y Huesca en el Alto Valle del Gállego (1426-1487), pp. 113-116.

${ }^{175}$ AHPH, Protocolo 8667, Jaca, 1413, fol. 96.
} 
En sesión plenaria habida en la sinagoga mayor, el 29-VIII-1412, bajo la presidencia de los adelantados rabí Mayr Almosnin, Açach Avingoyos y Mosse $\mathrm{Babo}^{176}$, se designa a Azerian Avingoyos, hijo de Judas, miembro de la mano mayor, y uno de sus más acaudalados judíos, para «manlevar quantias e pecunias a cumplimiento de seys mil sueldos» a través de cartas de comanda, garantizadas todas ellas con los bienes patrimoniales e individuales de la aljama y con la renuncia expresa a los jueces ordinarios judíos. Probablemente la desconfianza del delegado y el deseo de dotar de mayor solidez el compromiso de la comunidad los adelantados y todos los presentes «recibieron en si alalma hitada sobre aquellos por el rabi stant alto en la tribuna de la dita sinoga con la tora en las manos de non revocar la dita procuracion daquia que las manlievas e quantias manlevadas por el dito Azerian, procurador, con cartas sean firmadas e seguradas a plazer e voluntat de los crehedor o crehedores» ${ }^{177}$.

b) Deuda a largo plazo: los censales.

De los sucesivos pagos efectuados podemos deducir los gastos corrientes destinados al pago de intereses y a la amortización del principal, así como singularizar a sus tres principales acreedores.

$1^{\circ}$. El monasterio de San Juan de la Peña suscribió un censal de 600 sueldos de renta anual, que vencía cada primero de febrero, emitido por la aljama el 13-II-1400. Poseemos el albarán expedido por la clavería del monasterio relativos a los años $1413^{178}$ y $1419^{179}$.

\footnotetext{
${ }^{176}$ A la que asisten Jahuda Abambron, maestre Abram Avinacaya, Bonafos Alcala, Azarian Avingoyos, hijo de Jacob, Azerian Avingoyos, hijo de Judas, Abram Elnieto, Azerian Avingoyos, hijo de Sento, Açach Alcala, Bonafos Abambron, Jacob Tardiel, Abram Alcala, Azerian Gallipapa, Jucep Papur, Salamon Ampifaze Barchala Alcala, Simuel Alcala, Jucep Gallipapa, Sazon Alcala, Berchala Abambron, Jucep Ambinach, Faym Abambron, Jucep Avingoyos, Alazar Almosnin y Azerian Almosnin.

${ }^{177}$ AHPH Protocolo 8113, Jaca, 1412, fol. 35.

${ }^{178}$ En 1413, Domingo d'Orant, habitante en Jaca, procurador de don Fray Bendicho de Cantaviella, clavero mayor del monasterio de San Juan de la Peña, recibe de los adelantados de la aljama 600 sueldos censales correspondientes al año en curso. AHPH, Protocolo 8667, Jaca, 1413 , fols. 16 v. -17

${ }^{179} \mathrm{El} 16$ de marzo, fray Garcia de Baylo, monje y clavero del monasterio recibe la expresada cantidad de los adelantados por el ejercicio presente. AHPH, Protocolo 8669, Jaca, 1419, fols. 54 v. -55 .
} 
$2^{\circ}$. El mercader jacetano Ramón de Generes es el principal acreedor de la aljama a tenor de las compraventas de censales, formalizada la primera el 26-X-1401, por valor de 500 sueldos anuales que vencían el primero de agosto, y la segunda el 12-XI-1408, por una renta anual de 400 sueldos en la festividad de San Simón y San Judas.

Alguno de los recibos de estos 900 sueldos han quedado reflejados en los protocolos. El correspondiente a la tanda del año 1413 -librado el 17 de septiembre- en el que se amortizan 1.000 sueldos del principal ${ }^{180}$ y el de $1414^{181}$. Estas amortizaciones parciales de capital indican un deseo de reducir el déficit público que muy bien podía haber sido pactado en el contrato de cesión del principal. Cinco años después se inscribe el pago de 500 sueldos el 17 de agosto ${ }^{182}$.

$3^{\circ}$. Por último, han de recurrir al capital catalán. Así se deduce de la apoca extendida el 15 de enero de 1414 por Içach de Querço, judío de la villa de Cervera, procurador de Ramón de Torrellas, caballero, señor del lugar de la Rocas. La deuda ascendía a 400 sueldos barceloneses que le debían entregar en mayo de 1410, y en cuyo acto percibe las anualidades de 1411,1412 y $1413^{183}$.

\subsubsection{Gastos}

La comunidad ha de hacer frente a gastos ordinarios y extraordinarios. Los primeros se centran aquellos exigidos por el sistema fiscal real -aunque alguno de ellos se someta a fluctuaciones como es el caso de la demanda real-. Los segundos, sin someterse a la regularidad de aquéllos, tenderán a enjugar las imposiciones tributarias de organismos tales como el municipio o la iglesia. Las lagunas que puedan observarse en nuestra exposición son debidas a la discontinuidad de la documentación.

\footnotetext{
${ }^{180}$ AHPH, Protocolo 8667, Jaca, 1413, fol. 94.

${ }^{181}$ AHPH, Protocolo 8668, Jaca, 1414, fol. 76.

${ }^{182} \mathrm{AHPH}$, Protocolo 8669, Jaca, 1419, fol. 111.

${ }^{183} \mathrm{AHPH}$, Protocolo 8668, Jaca, 1414, fols. 15 v.-16.
} 


\section{a) Ordinarios}

Desde los primeros padrones de 1271 y 1274 , la judería de Jaca figura entre las 16 comunidades de Aragón que pagan autónomamente. Casi desde esta inclusión se suceden los problemas para cumplir puntualmente con los impuestos reales. Ya en 1260 Jaime I hubo de condonarles por un año 900 de los 1.900 sueldos a que había lugar ${ }^{184}$. En $1271^{185}$ y $1274^{186}$ se les conmutan 500 de los 2.500 sueldos $^{187}$ que en 1294 asciente a 1.871 sueldos ${ }^{188}$

A estas alturas cronológicas la presión fiscal debió alcanzar cotas poco soportables como corroboran las órdenes cursadas por Alfonso III, entre otros, a los oficiales de Jaca para que controlen las huidas de aquellos que querían evitar las exacciones reales trasnfiriéndose a lugares de señorío laico o eclesiástico. Estos deberían comparecer en juicio ante el justicia, bajo pena de subastar su patrimonio en pública almoneda ${ }^{189}$.

Esta insolvencia persistió e incluso se incrementó a lo largo de las dos últimas centurias medievales, llegando en las últimas décadas del siglo XV a amenazar con la quiebra financiera. Ya en 1337 Pedro IV, había encomendado a uno de sus más cercanos cortesanos, su médico Alatzar Abenardut, para que con Peregrino de Oblitas, justicia de Aragón, resolviera cierta cuestión relacionada con los impuestos que debía pagar la aljama a la cual no le alcanzaban los bienes para afrontarlos ${ }^{190}$.

Recordemos que, desde la concesión de Jaime II en 1291, goza de un estatuto de inmunidad por el cual para obtener el pago de los tributos no se podía privar a los judíos de alimento, ni retener a sus mujeres e hijos, embargar sus muebles o expulsarlos de sus casas; tan sólo se procedería al

\footnotetext{
${ }^{184}$ RÉGNÉ, History of the Jews in Aragon, doc. 134.

${ }^{185}$ Fritz BAER, Die Juden im Christlichen Spanien, doc. 103.

${ }^{186}$ Fritz BAER, Die Juden im Christlichen Spanien, doc. 120.

${ }^{187}$ Jaime II, en 1295 , llegará a expedir cartas de franqueza acodadas por cuatro años, en lo relativo a los impuestos de la pecha, subsidio y caballería. RÉGNÉ, History of the Jews in Aragon, doc. 2577.

${ }^{188}$ Manuel de Bofarull, Rentas de la antigua Corona de Aragón, en Colección de Documentos Inéditos del Archivo de la Corona de Aragón, Barcelona, Imprenta del Archivo, 1871, vol. XXXIX, p. 278.

${ }^{189}$ RÉGNÉ, History of the Jews in Aragon, doc. 2255.

${ }^{190}$ Antonio Cardoner Planas y Francisca Vendrell Gallostra, Aportaciones al estudio de la familia Abenardut, médicos reales, "Sefarad", VII (1947), p. 311.
} 
prendimiento de los morosos ${ }^{191}$. Esta aprehensión sólo podía llevarse a término en el supuesto de impago de pechas o exacciones reañes ${ }^{192}$. Téngase en cuenta que el fuero jacetano introducía numerosos elementos de inmunidad en las personas y en las cosas. Es más, en 1307 había dispuesto que ningún judío, por impago de los conceptos antes aludidos, podría ser recluido fuera de la judería, con el fin de que las familiares puieran llevar alimentos a los prisioneros sin ser objeto de escándalos 0 afrentas ${ }^{193}$. Desde siempre solía fraccionar su cuota «la meytat en jenero et en febrero et en março por tercias et la otra meytat en junio et julio et en agosto por tercias» ${ }^{194}$

A comienzos del siglo $\mathrm{XV}$ el patrimonio real arroja unos ingresos brutos de 2.460 sueldos jaqueses en concepto de treudo, pecha y cena real de ausencia, 1.460 de los cuales habían sido asignados a la cambra de Doña Violante $^{195}$ y los 1.000 restantes incorporados a la Corona ${ }^{196}$. A través de la sección del Maestre Racional de Valencia podemos seguir la pista de los pagos librados por esta aljama en este período:

Año $1405^{197}$

- La mitad del treudo

360 sueldos

-El resto de las rentas de la reina

110 sueldos

- La demanda ordinaria

80 florines

Año $1406^{198}$

-Pago de 70 sueldos por Todos los Santos

70 florines

\footnotetext{
${ }^{191}$ RÉGNÉ, History of the Jews in Aragon, doc. 2434. Este documento no es sino confirmción de otro rivilegio otorgado por Jaime I en 1263 por el que los colectores de la pecha sólo podían actuar contra los morosos cerrando las puertas de sus viviendas y tomando sus personas [Idem, doc. 233]

${ }^{192}$ RÉGNÉ, History of the Jews in Aragon, doc. 240. Jaime I, 1263.

${ }^{193}$ RÉGNÉ, History of the Jews in Aragon, doc. 2875.

${ }^{194}$ Bofarull, Rentas de la antigua Corona de Aragón, p. 278.

${ }^{195}$ Además de los peajes, almodí y derechos y rentas del mercado de Jaca, así como las del lugar de Canfrán y el castillo de Campdaljub. Bofarull, Rentas de la antigua Corona de Aragón, p. 185.

${ }^{196}$ Francisca Vendrell Gallostra, Rentas reales de Aragón en la época de Fernando I (1412-16), "CODOIN", XLVII (1977), p. 186.

${ }^{197}$ PILES, Situación económica de las aljamas aragonesas, p. 98.

${ }^{198}$ Ibídem.
} 
-Demanda real

Año $1407^{199}$

800 sueldos

Año $1408^{200}$

- La mitad del reudo pagadero en Navidad

360 sueldos

- La mitad de la cena real pagadera en enero

100 sueldos

- Por el resto de las rentas de la reina que recibe en mayo

110 sueldos

- La mitad del treudo que ha de pagarse en septiembre

- La mitad del subsidio pagadero en diciembre

- La mitad de la cena real de enero

750 sueldos

360 sueldos

100 sueldos

Año $1409^{201}$

-La demanda ejectuda en marzo

75 florines

Año 1413

-El treudo del mes de enero

360 sueldos

- La resta de las rentas pagaderas en mayo

- La cena ${ }^{202}$

110 sueldos

100 sueldos

Año $1414^{203}$

-El subsidio y tributo pagadero en diciembre

360 sueldos

- La mitad de la cena real que se abona en enero

100 sueldos

- La demanda

-El resto de lapecha que se hace efectiva en mayo

40 florines

- La pecha pagadera en septiembre

110 sueldos

750 sueldos

Año $1415^{204}$

- La resta del subsidio y tributo pagadero en diciembre

360 sueldos

-Pecha y subsidio pagadero en mayo

110 sueldos

\footnotetext{
${ }^{199}$ PILES, Situación económica de las aljamas aragonesas, p. 99

${ }^{200}$ Ibídem.

${ }^{201}$ Ibídem.

${ }^{202}$ AHPH, Protocolo de Pedro Alquezar, 1413, fol. 33.

${ }^{203}$ PILES, Situación económica de las aljamas aragonesas, pp. 99-100

${ }^{204}$ PILES, Situación económica de las aljamas aragonesas, p. 100.
} 
- La demanda

- Treudo pagadero en San Miguel de septiembre

40 florines

750 sueldos

Año $1416^{205}$

$-[\ldots]$ abonable en diciembre

360 sueldos

- Demanda

40 florines

- Tributo o subsidio de mayo

110 sueldos

- Treudo o subsidio pagadero en septiembre

750 sueldos

Año $1417^{206}$

-El treudo o subsidio pagadero en diciembre

360 sueldos

- Demanda

40 florines

- Subsidio o tributo del mes de mayo

- Treudo o subsidio anticipado de diciembre

110 sueldos

750 sueldos

\section{Año $1419^{207}$}

- Resta del subsidio o treudo del mes de diciembre

360 sueldos

- Resta del subsidio o treudo pagadero en sepbre.

750 sueldos

Si nos detenemos exclusivamente en el concepto de la «demanda ordinaria» observamos un acusado declive a partir de 1414 que no es indicio necesariamente de un descenso poblacional - aunque también - sino de un empobrecimiento material. Los registros contables de los años 1403, 1404 y 1406 demuestran que la carga fiscal en este concepto se mantiene estable en el nivel de los 70 florines, llegando a alcanzar los 80 en los ejercicios de 1405 y 1407. En este mismo segmento se sitúa la percepción de 1409 con 75 florines.

No conocemos el comportamiento impositivo hasta 1413 , en que Pedro de Banu, habitante en Canfranc, baile de la aljama, recibe, en nombre de la reina, 60 florines de manos de su adelantado Azerian Avingoyos, hijo de Judas, "por la demanda agora nuevament por ella a vos fecha» ${ }^{208}$. Esta contracción de los niveles de renta es irreversible pues un año después les

\footnotetext{
${ }^{205}$ PILES, Situación económica de las aljamas aragonesas, pp. 100-101.

${ }^{206}$ PILES, Situación económica de las aljamas aragonesas, p. 101.

${ }^{207}$ Ibídem.

${ }^{208} \mathrm{AHPH}$, Protocolo de Pedro Alquezar, 1413, fols. 32 v.-33.
} 
son exigidos 40 florines, que no experimentarán variaciones a lo largo de 1415 y 1416. Traducido en valores porcentuales, en tan sólo diez años, las tasas de liquidación por este concepto se reducirán en un $50 \%$. Este gradiente, por otro lado, es paralelo al alcanzado por otras aljamas próximas aunque por motivos muy diferentes.

La cena real parece consolidarse en 100 sueldos - la mitad de lo abonado en el último tercio del siglo XIII ${ }^{209}$-, siendo una de las partidas más modestas. Así lo atestiguan los pagos relativos al quinquenio 1410-1415. El 12-XI-1413, con notable retraso, eso sí, se satisfacen 400 sueldos relativos a los años 1410, 1411, 1412 y $1413^{210}$. El 31-VII-1414, los adelantados entregan idéntica cantidad a Pero Cruz de Salvalça, comisario del rey Fernando $\mathrm{I}^{211}$.

\section{b) Extraordinarios}

Como «cofres» y vasallos de la monarquía han de cumplir —en todo momento- el imperativo de ayudar en sus necesidades a su señor natu$\mathrm{ral}^{212}$. Su espectro es de los más variado, desde demandas de caballos y vituallas $^{213}$, subsidios ${ }^{214}$, viajes ${ }^{215}$. Si atendemos a estas prestaciones, y tomando como ejemplo, la solicitud de 7.742 sueldos que Alfonso III ejercita sobre nuestra comunidad de los 150.000 sueldos barceloneses que los

\footnotetext{
${ }^{209}$ Francisca Vendrell Gallostra, Rentas de la antigua Corona de Aragón, p. 480.

${ }^{210} \mathrm{AHPH}$, Protocolo 8720, Jaca, fol. 109.

${ }^{211} \mathrm{AHPH}$, Protocolo 8114, Jaca, fols. 39-39 v.

${ }^{212}$ Sirva como ejemplo el fuero de Teruel de 1176, modelo de otras cartas de repoblación de la extremadura aragonesa: «nam iudei servi regis sunt et semper fisco regio deputati». Cfr. Miguel Ángel Motis Dolader, Los judios turolenses en la Edad Media, en Los judios de la Corona de Aragón en los siglos XIV-XV, Valencia, Generalitat de Valencia y Doron Foundation for Education and Welfare, 1989, pp. 71-72.

${ }^{213}$ En 1282 don Alfonso solicita a la aljama jacetana un préstamo de 5.000 sueldos (en doc. 945 fechado el 13-VIII-1282 el recurre al justicia de Cariñena para que recaudara los 500 sueldos que la aljama la había pfrecido como subsisidio y que ascendía a 500 sueldos, cantidad que nos parece más acorde con la posición relativa en relación con las aljamas del reino); mientras que a la de Monzón pide 1.500 sueldos; 700 a Barbastro; 1.000 a Huesca; 500 a Ejea; 100 a Luna y 4.500 a Zaragoza. RÉGNÉ, History of the Jews in Aragon, doc. 936.

${ }^{214} \mathrm{En} 1287$ son gravados con 5.000 sueldos jaqueses. RÉGNÉ, History of the Jews in Aragon, doc. 1894

${ }^{215}$ Alfonso III pone en conocimiento de Guillermo de Becaria, merino de Ejea, que ha redimido a los judíos de Jaca 200 sueldos de los 1.000 que les había exigido para financiar su embajada a Roma en 1289. RÉGNÉ, History of the Jews in Aragon, doc. 1950.
} 
procuradores aragoneses se habían comprometido a entregarle en Bacelona, el peso contributivo se establecería en el $5 \%{ }^{216}$. Por su parte, en 1304, Vidal Lonieto, procurador de la aljama, en cumplimiento de la tecana de Zaragoza y Alagón, abona 1.562 sueldos de treudo ${ }^{217}$. En un contexto temporal similar, Jaime II, en 1320, dispone que de la composición de 90.000 sueldos asignados a los judíos aragoneses, 2.879 pesen sobre los contribuyentes jacetanos que, traducido en términos porcentuales, se establecería en un $3,2 \%{ }^{218}$.

Estos años con los que se inicia el siglo, con inacabables acciones bélicas y disturbios, precisaron de una continua afluencia de dinero. Una de las múltiples solicitudes de auxilio es recibida por la aljama de Jaca el 21-VI1413. Fernando I, apelando a la necesidad de «sustentar algunas grandes e excessivas expensas, las quales por las novidades en el regno d'Aragon subseguidas nos conviene suportar», rogándoles «que al presente nos soccorrades» con 1.000 florines de oro que se distribuirín según las instrucciones que recibieran de su delegado, mosén Anthon de Bardaxi ${ }^{219}$.

El mantenimiento de las defensas y murallas de la ciudad es una de las preocupaciones dominantes de las autoridades. Atención que podría hacerse extensiva a todos los núcleos urbanos hispánicos ${ }^{220}$. El propio Martín el Humano, pone de relieve en sus comunicaciones epistolares del 20-XII-1397, la importancia de la atención y mantenimiento no sólo por interés intrínseco, sino también por el del reino. No olvidemos su situación estratégica como plaza militar, fronteriza con los reinos de Francia, Navarra, Bearn y el condado de Foix; «alli donde hay mas peligro es donde debe procurarse mayor seguridad», sentenciaráa ${ }^{221}$.

Ciñéndonos a la época analizada, en marzo de 1390, se hace referencia expresa a la financiación de las obras de los muros y a su reparto. Juan Perez de Caseda, jurisperito, lugarteniente del Justicia de Jaca, requiere

\footnotetext{
${ }^{216}$ RÉGNÉ, History of the Jews in Aragon, doc. 1565.

${ }^{217}$ BAER, Die Juden im Christlichen Spanien, doc. 155.

La negociación de las cargas tributarias suele encomendarse a delegados de la comunidad que se desplazan a la capital del reino o allí donde dispone el rey o las demás aljamas. En 1271, por poner un ejemplo, la jacetana desplazó a cuatro emisarios.

${ }^{218}$ RÉGNÉ, History of the Jews in Aragon, doc. 3139.

${ }^{219} \mathrm{ACA}$, Cancillería, reg. 2403, fol. 13.

${ }^{220}$ José María, Font RiUs, Les villes dans l'Europe du Moyen Âge, "Recueils de la Societé Jean Bodin", VI (1954), p. 290.

${ }^{221}$ BAER, Die Juden im Christlichen Spanien, doc. 102, p. 244.
} 
a la aljama al pago, pues hasta la fecha se habían negado. El origen de la discrepancia estaba en el porcentaje de la prorrata que les adjudicaba un tercio del gasto, cuota que por su peso demográfico y económico aducían no les correspondía. Este ha de fallar el recurso interpuesto por los ediles de la ciudad ante la «necesitas operandi seu constituendi, menia, turres, seu valles adque calliadas in dicta civitate Jacce reparandi vel fortifficandi», cuya porrata «ab antiquisimis temporibus» se distribuía del siguiente modo: 1/6 clérigos; 2/6 judíos \& 3/6 infanzones, jurados y hombres de condición. Los judíos disponen de diez días para plantear una iuris firma ${ }^{222}$ con los correspondientes pliegos de alegaciones ${ }^{223}$.

Lo cierto es que en 1283 don Alfonso había ordenado a los judíos de Jaca - al igual que a los de Gerona - que contribuyeran por la mitad con los infanzones y eclesiásticos en la reparación de las torres y murallas de sus respectivos castillos y fortalezas ${ }^{224}$. Además, habían de participar en la fortificación y los gastos de la guerra con las sumas siguientes ${ }^{225}$ :

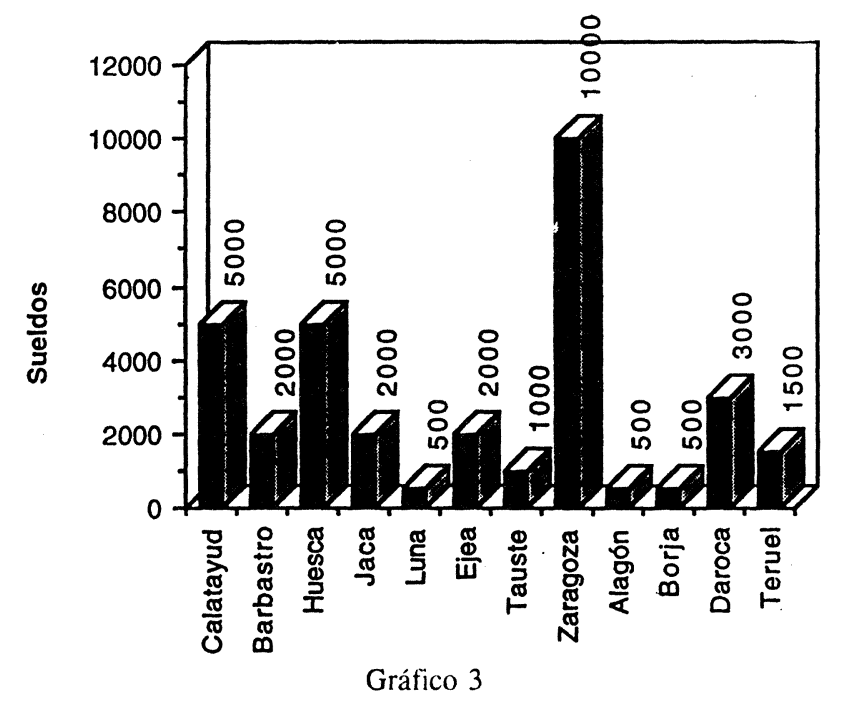

\footnotetext{
${ }^{222}$ Ángel BonET NAVARro, Procesos ante el Justicia de Aragón, Zaragoza, Guara Editorial, 1982, pp. 108-133.

${ }^{223}$ AMJ, Caja 25, Papeles sueltos en pergamino, doc. suelto.

${ }^{224}$ RÉGNÉ, History of the Jews in Aragon, doc. 1019.

${ }^{225}$ RÉGNÉ, History of the Jews in Aragon, doc. 2116.
} 


\section{HÁBITAT URBANO}

Aproximémonos ahora menos al problema del emplazamiento de la judería a principios de siglo, para lo cual apelaremos a la microtoponimia que se muestra en la documentación y a su correlato con el callejero más antiguo de la ciudad ${ }^{226}$.

\subsection{El barrio y su situación}

El origen del asentamiento judío de la ciudad va más allá de la configuración jurídica de este núcleo y su dación de fueros por Sancho Ramírez, aunque la mención más antigua se refiera a los albores del siglo XI -entre los años 1020 y $1030^{227}$ - . Algunos autores han opinado sobre su ubicación más racional. Así, J. M. Lacarra ${ }^{228}$ entiende que el barrio judío estaba incluido en el anterior del alargamiento expansivo de la ciudad hacia el sur, mientras que D. Buesa ${ }^{229}$ rompiendo con esta tónica imperante defiende un barrio preexistente - es el primero que se plantea dos asentamientos sucesivos- que ocuparía el espacio comprendido entre la puerta de S. Ginés y la calle de San Nicolás.

Dada la existencia plurisecular de esta minoría es factible pensar en fases evolutivas. En 1063 la población - incluida la hebrea- se concentra en la «villa» real, en los alrededores del monasterio de San Pedro. Desde este momento hasta fines del siglo XI se repuebla y extiende hacia los barrios cerrados que se prolongarían por la calle del Coso. Después de 1135 la villa, sobre la que se alzaba el castillo del Castellar, se rodea de murallas.

\footnotetext{
${ }^{226} \mathrm{Cf}$. Miguel Ángel MOTIS DOLADER, Reflexiones en torno a las sinagogas de la judería de Jaca en la Edad Media, "Aragón en la Edad Media. Homenaje a la Dra. María Luisa Ledesma Rubio", Zaragoza, 1993, pp. 641-660.

${ }^{227}$ Urraca Jimenez formaliza la adquisición de siete yeguas a un judío de la localidad que atiende al nombre de Bellito - «VII equas ad Bellito, iudeo maiore, de kastro quod vocatur Iaka, frater enim fuit de iudeo qui vocatur Azaka»-. Cfr. Miguel Ángel Motis DoLADER, Contexto histórico-jurídico de los judíos del Reino de Aragón (ss. XI-XII): pluralidad normativa y preconfiguracion de las aljamas, en "Estudios sobre Pedro Alfonso" en "Estudios sobre Pedro Alfonso de Huesca", Huesca, Instituto de Estudios Altoaragoneses, 1996, pp. 49-146.

${ }^{228}$ José María LACARRA, Desarrollo urbano de Jaca en la Edad Media, pp. 139-155.

${ }^{229}$ Domingo BUESA CoNDE, Jaca, dos mil años de historia, Zaragoza, 1982, p. 145.
} 
En 1161 Ramón Berenguer dona a los habitantes del Castellar, francos y libres, el derecho de cultivar unas tierras situadas al Oeste de Jaca ${ }^{230}$.

Serra Ráfols deduce de una carta de Fernando el Católico, consignada el 27-XII-1494 al baile de Jaca, concediendo al municipio engrandecer la Escuela de Arte a costa de la sinagoga mayor y sus anexos, la sitúa en el lugar donde hoy se encuentra el Cuartel del Estudio. Esta ubicación el propio autor reconoce que es muy discutible ${ }^{231}$. En efecto, como demuestra J. Passini ${ }^{232}$, sirviéndose del callejero de 1718 , en el siglo XVIII el espacio ocupado por el Cuartel del Estudio no tenía construcciones.

Las murallas de la ciudad cernían la zona sur. La calle del Castellar que comenzaba en la puerta de los Baños y terminaba en la misma muralla era denominada por algunos como la calle del $\operatorname{saco}^{233}$. El Coso de extendía desde la puerta de los Baños hasta la esquina del convento de Santo Domingo. Detrás de los huertos que ocupaban una importante parte de las parcelas perpendiculares a la calle del Coso se extendían los campos.

La calle del Ferrenal -que en el siglo XVIII tenía una ongitud mínima de 6,5 metros- acababa, a principios del siglo XX, en la puerta del Estudio. Es previsible, por tanto, que el Estudio estuviera edificado próximo a la calle del Ferrenal en razón del nombre dado a la puerta en la cual moría esta arteria viaria y la calle en sí misma que se llamaba hacia 1664 Barrio del Estudio ${ }^{234}$.

Las parcelas que bordean la calle del Ferrenal se dividían en lotes de una parte de la calle de las Cambras hacia el sur y de otra de la muralla hacia la calle de las Cambras. Habiendo ocupado los cristianos el barrio de la calle del Ferrenal en su zona exterior, el Estudio estaría edificado en sus aledaños. La sinagoga mayor utilizada para engrandecerlo se situaría en la cara este de la calle del Ferrenal en las proximidades de la calle Cambras $^{235}$.

\footnotetext{
${ }^{230}$ D.D. SANGORRÍN Y Diest-GARCÉS, El libro de la Cadena de Jaca. Documentos reales, episcopales y municipales de los siglos X, XI, XII y XIV, Zaragoza, 1921, p. 168.

${ }^{231}$ E. SERRA RÁFols, Fernando el Católico y la ciudad de Jaca, "Jerónimo Zurita, Cuadernos de Historia", 10-11, pp. 279-283.

${ }^{232}$ Jean PASSINI, La juderia de Jaca, structure urbaine, en "Minorités et marginaux en Espagne et dans le Midi de la France (VIIe-XVIIIe siècles)", figura 3.

${ }^{233}$ PASSINI, La juderia de Jaca, p. 147.

${ }^{234}$ Ibídem.

${ }^{235}$ PASSINI, La juderia de Jaca, p. 148.
} 
Observamos en el interior de los límites de la villa del siglo XI dos barrios rodeados por dos calles acodadas: el barrio de Santiago y las Cambras. Tortuosa la calle de las Cambras da comienzo en la calle de Santo Domingo. Estrecha en su primer tramo se ensancha en forma de embudo en la confluencia con la calle del Pilar, recibiendo, todavía en 1657-1697, el nombre de la calle de la Judería ${ }^{236}$.

La calle del Pilar, que comienza en la plaza del mismo nombre, en el siglo XVIII se interrumpía en la calle de $\operatorname{Cambras}^{237}$ y tenía el nombre de Churrundiella, después de haber llevado también el nombre de la Judería en el siglo XVI. Precisamente en las fuentes utilizadas se incide con insistencia en esta localización, con sus más variadas acepciones: «qurandiella», «jurandiella» o «jerundiellya». En ese barrio se enclavan los huertos de Azerian Avingoyos, hijo de Sento; Duenya, viuda de Fahim y Jacob Abambron ${ }^{238}$; Ceti, mujer de Jacob Abambron de Sos ${ }^{239}$; maestre Abram Abenacaya $^{240}$; y las casas de Jacob Cardeniel ${ }^{241}$. Posiblemente existía una puerta para cerrar la calle de Cambras y Churundiella al nivel del estrechamiento. Por otro lado, en el siglo XVIII dos vías sin salida partían acodadas de Churundiella y Cambras.

La edificación a comienzos del siglo XVIII del convento de Santo Domingo donde se elevaba la antigua iglesia de Santiago modificó profundamente el entorno y su configuración. El barrio de las Cambras generaba sobre sí mismo antes del siglo XVII, conserva incluso en el siglo XVIII en su toponimia y en su morfología caracteres muy próximos a la ciudad de Fernando $\mathrm{II}^{242}$.

En tan estrecho margen cronológico resulta muy difícil reconstruir su patrimonio inmobiliario, pues frente a la segunda mitad de esta centuria, en que aparecen incluso cartas públicas de reparación de fincas, hemos de recurrir a actuaciones donde es mencionado de modo circunstancial. La judería tenía una clara funcionalidad residendial, aunque no descartamos la

\footnotetext{
${ }^{236}$ Ibídem.

${ }^{237}$ PASSINI, La juderia de Jaca, figura 3.

${ }^{238}$ AHPH, Protocolo 8666, Jaca, 1410, fols. 43 v.-35.

${ }^{239} \mathrm{AHPH}$, Protocolo 8666, Jaca, 1410, fol. $44 \mathrm{v}$.

${ }^{240} \mathrm{AHPH}$, Protocolo 8668, Jaca, 1415, fol. $74 \mathrm{v}$.

${ }^{241}$ AHPH, Protocolo 8666, Jaca, 1410, fol. $44 \mathrm{v}$.

${ }^{242}$ E. SERRA RÁFols, Fernando el Católico y la ciudad de Jaca, pp. 282-283.
} 
presencia de obradores. Lo que sí parece es que la función comercial intercomunitaria se realiza extramuros, como lo denuncian las sucesivas querellas y disputas surgidas sobre el horario y calendario de apertura comercial y la política segregacionista. Existe, por otro lado, un porcentaje difícilmente evaluable de solares no edificados dedicados a pequeñas explotaciones familiares, léanse huertos y corrales.

El caserío del barrio estaba muy degradado, o mejor, en período de reconstrucción. Si algún incendio se conserva vívido en la memoria de sus moradores, éste es el que se declaró - al parecer de modo casual- en 1375. Uno de los eruditos de la ciudad, en su edición del Libro de la Cadena - libro del concejo de Jaca donde se asentaban las cartas reales y municipales de mayor interés para el regimiento y administración de la ciudadrememora que en el mes de julio de aquel año quedó destruida en pocos días la mayor parte del barrio cristiano - se calcula en torno a los 150 edificios afectados-. Las llamas asolaron en su práctica totalidad el barrio hebreo $^{243}$

La historiografía recoge otro siniestro anterior no tan devastador, cuya incidencia sobre la judería desconocemos, pero que debió alcanzar dimensiones considerables por cuanto originó el otorgamiento de un privilegio del infante Juan, hijo de Pedro IV, el 22-VIII-1375, donde se transfería a la ciudad el cobro del peaje y pontazgo del paso de Canfrán por espacio de 6 años con el fin de reparar y reconstruir las casas damnificadas. Dos concejales se ocuparían de repartir entre los afectados las cantidades percibidadas según la gravedad de los daños ocasionadas en sus domicilios y en sus comercios ${ }^{244}$.

\subsection{Inmuebles de uso privado}

Por norma general cada hogar dispone de un pequeño huerto o corral donde proveerse de alimentos de primera necesidad. La judería cuenta con amplias zonas verdes, indicio de que no había una alta densidad de población como en Zaragoza, que había obligado a edificar todo el suelo urbanizable.

La extrema necesidad de algunos miembros de esta comunidad posibilita que, en especial las viudas, hayan de desprenderse de parte de sus

\footnotetext{
${ }^{243}$ D.D. SANGorRín Y DIEST-GarcÉs, El libro de la Cadena de Jaca. p. XXII

${ }^{244} \mathrm{AMJ}$, Caja 24, Documentos sueltos, traslato contemporáneo. 22-VIII-1375.
} 
bienes raíces. El 27-XI-1413, en la «judaria», se persona Salamon Almosnin, alias Motes, para tomar posesión de unos inmuebles que le habían empeñado por 500 sueldos durante 3 años sus propietarios Duenya, viuda de Faym Almosnin, maestre Abram Abenacaya y Jamila hija del primero y mujer del segundo. Las casas confrontan con casas de Davit Avingoyos alias Bonanat, casas de Açach Avingoyos, hijo de Azarian, y casas de Sorbellita, viuda de rabi Simuel; el huerto anejo linda con dos carreras públicas y unas casas y huerto de Sorbellita ${ }^{245}$.

El 28-XII-1418, Pero Sparça, sastre, y su hijo Leonart, habitantes en Jaca, donan a Eçer, judía, madre del primero, unas casas ${ }^{246}$ confrontantes con casas de Domingo de Gaço, Pero Çelun -en dos de sus laterales-, unas casas de la almosna y una carrera pública. Esta viuda de Açach Abenmielca ${ }^{247}$ se quedó muy desasistida de recursos pues se vio obligada a venderlas por 3.000 sueldos a los hermanos Gento y Jassuas Andali, al día siguiente ${ }^{248}$, debiendo suscribir un crédito comanditario con garantía hipotecaria de 2.700 sueldos por su carencia de numerario con intervención de sus respectivas mujeres - ambas se llaman Sol- ${ }^{249}$.

Otra donación, esta vez entre cónyuges, se produce en 1419, en que Açach Avingoyos, hijo de Azarian, judío, le cede gratuitamente a Duenya las casas de su residencia con un subterráneo con sus cubas, cubiellos, ornales y arquibanquos ${ }^{250}$. Por su parte, en 1410, Azerian Avindaut, físico, dona a Sorbellita y Miriam, hijos de David Avingoyos, alias Bonanat, y Ceti, su mujer, sobrinos suyos, unas casas con un pozo confrontantes con casas de Açach Avingoyos y casas de Aznar de Acomuer ${ }^{251}$.

\footnotetext{
${ }^{245}$ AHPH, Protocolo 8667, Jaca, 1413, fol. 62.

${ }^{246}$ AHPH, Protocolo 8669, Jaca, 1419, fols. 2 v. -3.

${ }^{247} \mathrm{AHPH}$, Protocolo 8669, Jaca, 1419, fol. 9.

${ }^{248}$ AHPH, Protocolo 8669, Jaca, 1419, fols. 5 v. -9.

${ }^{249}$ Plazos de amortización estipulados en la comanda del 30 de diciembre, viernes [AHPH, Protocolo 8 669, Jaca, 1419, fols. 10 v.-12]: 1.000 sueldos en Pascua Florida; 400 sueldos en San Miguelde Septiembre; 300 sueldos en la Pascua Florida de 1420 y 1.000 sueldos a la muerte de Eçer [AHPH, Protocolo 8669, Jaca, 1419, fols. 13-14]

${ }^{250} \mathrm{AHPH}$, Protocolo 8669, Jaca, 1419, fols. 23 v.-24.

La información que hemos podido colectar sobre el mobiliario que, rara vez, se plasma Podemos agregar tan sólo la venta efectuada, el 30-VI-1419, por Johan de Navasa, habitante en Brunas, a Abram Gallipapa, hijo de Binafos, de un arca de fusta nueva de pino con una capacidad aproximada de 4 cahíces, por 20 sueldos. AHPH, Protocolo 8669, Jaca, 1419, fol.

${ }^{251}$ AHPH, Protocolo 8112, Jaca, 1410, fols. 223 v. -224.
} 82 . 
Un modo muy frecuente de que salgan a colación consiste en su presentación como garantía hipotecaria de los préstamos, de donde se deduce, entre otros extremos, el valor mínimo de la finca. El 5-V-1410 Azerian Avingoyos, hijo de Sento, como fianza de 5 quintales de lana, presenta un huerto franco en «qurandiella» confrontante con un huerto de Duenya, viuda de Fahim Almosnin, huerto de Jacob Abambron y dos carreras públicas $^{252}$. En el mes de octubre de aquel mismo año en conjunción con su mujer Jamila, tras recibir en comanda 485 sueldos, compromete unas casas francas «do nos semos habitacion» limítrofes con casas de Sento Abrambron, casas de Juce Abambron y una vía pública ${ }^{253}$.

El 2-VII-1410, Ceti, mujer de Jacob Abambron de Sos, garantiza una comanda de 380 sueldos con un huerto «a la jurandiella» lindante con casas de Jacob Cardeniel, huerto de Azerian Avingoyos y una carrera pública; amén de unas casas en la judería confrontantes con casas de Abram Lonieto, casas de Ażerian Avingoyos, hijo de Judas y una carrera pública; y unas casas de su habitación francas confrontantes con casas de Juce, corredor, y casas de Juce Abambrón ${ }^{254}$.

El 26-VII-1414, Exemeno de Tarasone y su mujer Pascuala, habitantes en Jaca, venden a Gil de Carastue, hijo de Gil, vecino de Jaca, un huerto o parral franco en la juderia «a jerundiellya» confrontante con huerto de maestre Abram Abenacaya, huerto de Jacob Abambron, alias Jacobet, y dos carreras públicas, por 60 florines; luego la propiedad inmobiliaria de la judería no está en su totalidad en poder de los judíos ${ }^{255}$.

El 25-XI-1410, Jacob Amosnin, hijo de Juce, en respuesta a una comanda de 18 florines y 15 dineros pone en garantía unas casas «en la carrera de la sinagoga», afrontantes con casas de Azerian Larros y casas de Çaçon Almosnin ${ }^{256}$.

Respecto al medio contractual más usual de explotación destaca el arrendamiento o treudo enfitéutico del que poseemos un sólo ejemplo debido en parte a un alto porcentaje de propiedad franca. El 14-III-1410 Sorbellita,

\footnotetext{
${ }^{252}$ AHPH, Protocolo 8666, Jaca, 1410, fols. 43 v. -35 . Jaca.

${ }^{253}$ AHPH, Protocolo 8666, Jaca, 1410, fol. 65. Acreedor de Gil de Caraseve, vecino de

${ }^{254} \mathrm{AHPH}$, Protocolo 8666, Jaca, 1410, fol. $44 \mathrm{v}$.

${ }^{255} \mathrm{AHPH}$, Protocolo 8668, Jaca, 1415, fol. $74 \mathrm{v}$.

${ }^{256} \mathrm{AHPH}$, Protocolo 8666, Jaca, 1410, fol. 64 v. Acreedor prestados por Pedro de Lanaguerre, habitante en Ravasieda.
} 
viuda de rabí Simuel, atreuda por 10 años a Martín de Latre, vecino de Jaca, un «troç de huerto» situado entre los huertos de Ramon de Arguis, huerto de Salamon Ampifaç, huerto de Judas Avingoyos, hijo de Azerian, huerto de Martín de Latre. En la Pascua Florida habrá de pagar 2 sueldos teniendo la obligación de plantar árboles frutales ${ }^{257}$.

\subsection{Inmuebles de utilidad pública}

Descuella con personalidad propia la sinagoga, lugar donde se producen las reuniones plenarias de la aljama. Debían existir dos, al cualificar a la primera como mayor - aunque no se mencione la menor hasta muy avanzado el siglo ${ }^{258}$ - Se emplazaba en una de las arterias principales de la judería - ¿la calle de las Cambras? - pues en un acto comanditario se habla de «la carrera de la sinagoga ${ }^{259}$.

En otros trabajos precedentes insistíamos en el especial cuidado con que se articulaba la distribución de los asientos, imponiendo severas penas a quienes insistían en ocupar los que habían sido designados a otros. En algunas aljamas eran adjudicados por comités especiales, designados a tal efecto, en otras, - la mayoría- eran vendidos, en cuyo caso eran de propiedad privada, pudiendo hacer de ellos a su antojo (enajenarlos, arrendarlos), lo que acarreaba encendidas polémicas por su acaparación, disipado, en parte, por promulgación de leyes específicas sobre la compraventa de asientos - ley de bar-mizrah- ${ }^{260}$ por la cual si el dueño de un asiento deseara venderlo, el derecho preferencial pertenecía al vecino colindante ${ }^{261}$.

Esta valoración social de que gozaban permitía que fueran empleados como fianzas, como lo refrenda el acto celebrado en febrero de 1410 por el que David Alcala, hijo de Sento, y su mujer Bellita comprometen con su

\footnotetext{
${ }^{257}$ AHPH, Protocolo 8666, Jaca, 1410, fol. $23 \mathrm{v}$.

${ }^{258}$ Motis, La judería de Jaca en el siglo XV, op. cit.

${ }^{259} \mathrm{AHPH}$, Protocolo 8666, Jaca, 1410, fol. $64 \mathrm{v}$.

${ }^{260} \mathrm{Como}$ botón de muestra recordemos la haskama que dictaron los mukdamin de Borja a propósito de la distribución de asientos en la nueva sinagoga que había sido decidida por un comité designado a tal efecto, bajo pena de niddui, pues había levantado una viva polémica entre los que se sintieron más postergados. Su autoridad moral además de legitimarla contribuyó a acallar los descontentos. Miguel Ángel MOTIS DOLADER, Judíos y judeoconversos en la Raya Occidental en la Edad Media, op. cit.

${ }^{261}$ Abraham Moses HẹSHMAN, Rabbi Isaac ben Sheshet Perfet and his times, pp. 141-142.
} 
acreedor Salvador de Generes - que les acababa de encomendar 96 sueldos«unos sitios que havemos en la sinagoga de la dita ciudat». El marido se aposentaba entre Mosse Belbo y Faym Abambron, mientras que su mujer entre Sol, mujer de Bonafos, y Duena, mujer de Açach Avingoyos ${ }^{262}$

En un acto público, celebrado el 20-III-1419, comparecen los adelantados rabí Abram Abinpapur y Salamo Almosnin, «delant de los banyos de los judios de la dita ciudat", a raíz de la necesidad de emprender el adobo o reparación de una resa que se encontraba en malas condiciones y perjudicada al huerto de Martin de Pardiniella en la distribución de la canalización y en la mitad de las aguas residuales ${ }^{263}$ - una immissio dañosa evidentemente - en lo que el derecho romano conoce bajo la sentencia actio aquae pluviae arcendae ${ }^{264}$.

Por último decir que en 1062 Sancho Ramírez liberó a los habitantes de Jaca de la obligación de moler su harina en los molinos del Señor, de cuyo acto de liberalidad no se beneficiaron ni judíos ni panaderos: «et quod omnes homines vadant ad molendum in molendinis, ubi voluerint, exceptis iudeis, et qui panem causam venditionis faciunt ${ }^{265}$.

\section{GEOGRAFÍA ECONÓMICA}

Siguiendo un criterio clásico dividiremos la actividad económica en los sectores tradicionales: agricultura, comercio, industria artesanal y el préstamo.

${ }^{262}$ AHPH, Protocolo 8112, Jaca, 1410, fol. 11.

${ }^{263} \mathrm{AHPH}$, Protocolo 8669, Jaca, 1419, fol. 57.

${ }^{264}$ Digesto, 39, 3, 2, 9 bajo el supuesto interpolado de que el agua afluya en proporción no. natural a causa de una obra artificial: curare ne (aqua) influat.

${ }^{265}$ Fritz BAER, Die Juden im Christlichen Spanien, doc. 6. 


\subsection{Explotaciones agrarias ${ }^{266}$}

La propiedad de la tierra y su explotación no constituye una fuente primordial entre los judíos jacetanos. Sin embargo, dentro de la categoría de propietarios no cultivadores o absentistas, existe interés por rentabilizar y racionalizar sus terrazgos poniéndolos en circulación a través del circuito de los arrendamientos rústicos. No tenemos constancia de la explotación directa $^{267}$-si excluimos los pequeños fundos familiares destinados al autoconsumo-, decantándose por los contratos agrarios de «dación a labrar» o a labor.

En la actividad contractual distinguiremos los documentos suscritos por personas físicas y jurídicas -instituciones aljamales y corporaciones en general- pues las clausulas mantienen algunas diferencias. Comenzaremos mostrando los escasos ejemplos que poseemos de contratos signados por particulares. A tal fin seguiremos un estricto orden cronológico ${ }^{268}$.

El 24-VI-1410, Salamon Ampifaç, hijo de Simuel, entrega a «lavor» a Garcia de Berunas, habitante en Jaca, una viña franca, situada en el fosar de los judios ${ }^{269}$, confrontante con una viña de la almosna de los judíos y dos carreras públicas. Se pacta un censo de 1/6 de la producción por espacio de un quinquenio. Durante ese tiempo, «en adiutorio de la dita viña», le hará entrega de 12 docenas de palos. Nos preguntamos si ello no significa que existen plantadas en la propiedad un mínimo de 144 cepas o se tiene pretensión de plantar nuevos majuelos en el número indicado ${ }^{270}$.

El 30-XII-1412, maestre Abram Abenacaya, entrega a labrar a Martin Cavero, vecino de Jaca, una viña suya en Ribafreyta, por espacio de 10 años -10 collidas-. Deberá introducir mejoras, nunca causarle daño;

\footnotetext{
${ }^{266}$ En este capítulo se incluye únicamente la periferia rururbana no así las pequeñas explotaciones domésticas, léase huertos primordialmente, enclavados en la judería pues los consideramos parte integrante de la propiedad dominial, es decir, dependencia de la vivienda donde reside la familia judía y de la que se abastece de alimentos de primera necesidad.

${ }^{267}$ Es impensable, aun en el caso de artesanos plenamente integrados en un mercado urbano, renunciar a la propiedad de la tierra; ella supone un seguro en momento de crisis de la economía familiar y un aporte de alimentos y materias primas -cultivada por hijos $u$ otros miembros de la familia, mozos- o dinero -logada o arrendada-. La tierra es fundamentalmente seguridad para el hombre medieval.

${ }^{268} \mathrm{Cfr}$. Cuadro $\mathrm{n}^{\mathrm{o}}$. 1. Contratos agrarios suscritos por los judíos de Jaca (1410-1419).

${ }^{269}$ Mientras no manifestemos nada en contrario se enclavan dentro del término de Jaca.

${ }^{270}$ AHPH, Protocolo 8666, Jaca, 1410, fol. 39 v.
} 


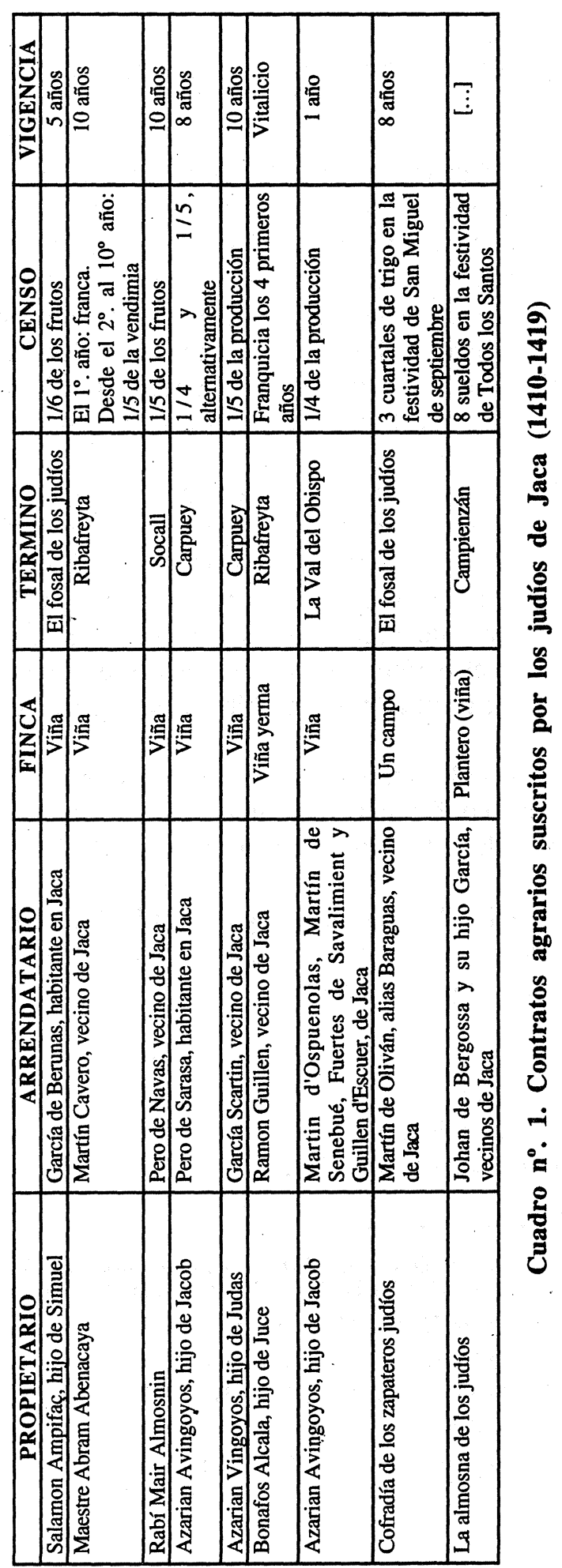


tenerla en labranza con todas las labores requeridas como podar, ligar, cavar, hedrar, margonar, etc. ${ }^{271}$. El primer año se le exime del pago de toda gabela - «que no fagades de aquella cosa alguna»-, mientras que los 9 años restantes le hará entrega de $1 / 5$ de lo vendimiado ${ }^{272}$.

Estas condiciones tan ventajosas para el arrendatario delatan unos índices de baja productividad y quizás también un bajo coeficiente de mano de obra, mala calidad del suelo y extensión reducida. Se persigue la atracción de mano de obra sin vincularla a perpetuidad en el predio aunque sí con la suficiente estabilidad como para que se produzcan mejoras ostensibles.

Esta proporcionalidad en los derechos percibidos por el cedente de la explotación parece moverse en un estrecho margen de fluctuación, como así lo demuestra un nuevo contrato suscrito entre rabí Mair Almosnin y Pero de Navas, por el cual, el 10-II-1413, el primero entrega al segundo una viña situada en el término de Socel, por espacio de 10 años y $1 / 5$ del fruto ${ }^{273}$. Es manifiesto que el período en que permanece en vigor el documento es muy extenso lo que resultaría inconcebible si se tratare de tierras de la vega o de regadío.

El 6-XII-1413, Azarian Avingoyos, hijo de Jacob, da a labrar una viña en Carpuey, confrontante con una viña de Dueña y un barranco, a Pedro de Sarasa, durante 8 años y con un censo de $1 / 4$ y $1 / 5$, alternativamente ${ }^{274}$.

El 26-XII-1418, Azerian Avingoyos, hijo de Judas, entrega una viña en Carpuey a Garcia Scartin, vecino de la ciudad -entre cuyas confrontaciones se da cita un campo del propietario judío- por espacio de 10 años y a $1 / 5^{275}$.

El 27-XII-1418, Bonafos Alcala, hijo de Juce, entrega a labrar a Ramón Guillen, vecino de Jaca, una viña yerma franca en Riba Freyta, durante 4 años, percibiendo $1 / 5$ del fruto, siendo franco el primer año. Se prohibe que pueda ser subarrendada ${ }^{276}$.

\footnotetext{
${ }^{271}$ Miguel Ángel Motis DoLADER, Explotaciones agrarias de los judios de Tarazona (Zaragoza) a fines del siglo XV, "Sefarad", XLV (1985), pp. 353-390.

${ }^{272}$ AHPH, Protocolo 8667, Jaca, 1413, fols. 3-3 v.

${ }^{273}$ AHPH, Protocolo 8667, Jaca, 1413, fols. 17 v. -18 .

${ }^{274}$ AHPH, Protocolo 8667, Jaca, 1413, fols. 121 v. -122 .

${ }^{275}$ AHPH, Protocolo 8669, Jaca, 1419, fols. 1 v.-2.

${ }^{276}$ AHPH, Protocolo 8669, Jaca, 1419, fols. 2-2 v.
} 
El 1-V-1419, Azarian Avingoyos, hijo de Jacob, entrega a- «lavor» una viña en La Val del Vispo, confrontante con una viña de Sorbellita, una viña del otorgante y una vía pública, a cuatro labradores jacetanos -quizás en calidad de jornaleros-: Martin d'Ospuenolas, Martin de Senebue, Fuertes de Savalimient y Guillen d'Escuer. Si es cierto que la extensión o la productividad varía a tenor del número de los concurrentes, se desprendería que esta finca era de grandes dimensiones - siempre relativizado en una economía de montaña-. Téngase en cuenta además que sólo trabajarán en ella un año - es decir, un tempero- y el dueño se reserva el derecho a ingresar el $1 / 4$ de la producción ${ }^{277}$.

Dado el tamaño de la muestra no es posible deducir comportamientos cuantificables estadísticamente, pero sí es posible diseñar algunos rasgos generales $^{278}$. En primer lugar se advierte que el contrato suscrito es invariablemente la "aparcería ${ }^{279}$, por la cual se requiere del arrendatario especialmente la inversión humana y económica -en forma de trabajodetrayendo parte del producto el propietario como remuneración por su título de propiedad. Se desechan los contratos que contemplan el censo enfiteútico perpetuo por su carácter antieconómico y porque este tipo de canon recognitivo pudiera transformarse, al calor de su perdurabilidad en una cuasi propiedad $^{280}$. No se deduce una consistente inversión en medios de producción primarios - adquisición de tierra-.

Los contratos parciarios requieren la cumplimentación de una serie de premisas: endeudamiento campesino y destrucción de la pequeña propiedad, lo que conlleva la explotación del trabajo de los labriegos - la mano de obra procede de Jaca o sus alrededores- en el mercado del arrendamiento. La presencia del contrato arrendaticio significa una porción no desdeñable de cultivadores que tenían vedado el acceso a la propiedad por lo que debían emprender este tipo de relaciones contractuales.

${ }^{277}$ AHPH, Protocolo 8669, Jaca, 1419, fols. 65-65 v.

${ }^{278}$ Sí es posible hacerlo para el último tercio del siglo XV. Miguel Ángel MOTIS DOLADER, Régimen jurídico de los contratos pecuarios suscritos en Jaca durante el siglo XV, "XV Congreso de Historia de la Corona de Aragón", Jaca, 1994, pp. 327-340.

${ }^{279}$ Miguel Ángel MOTIS DOLADER, Régimen de explotación de las propiedades agrarias de los judios en el noroeste del reino de Aragón en el siglo XV, "Hispania", XLVIII/169 (1988), pp. 437-441.

${ }^{280}$ Bartolomé ClAVERO, Enfiteusis. ¿Qué hay en un nombre?, "Anuario de Historia del Derecho Español", LVI (1986), pp. 467-519. 
La acción antrópica es irrelevante pues el pilar de su economía es más pecuario que agrícola. La agricultura se reduce a los valles donde el suelo retiene la tierra vegetal, principalmente el de Borau y el Campo de Jaca y el valle de Tena, fertilizados por el río Gállego. Tómese como nota comparativa que en 1777 se censaban 6.670 cahizadas $^{281}$ de tierra cultivada -mientras que los pastos y tierras incultas se elevaban a 5.700-. Además, de la tierra cultivable sólo 70 cahizadas lo eran de regadío aprovechando los cursos del Aragón, Gas y Archen y otras 60 en el valle de Tena ${ }^{282}$.

El paisaje agrario dominante es el viñedo. No se citan apenas yermos, lo que induce a pensar en tierras marginales o en una escasa presión demográfica que frena la expansión del labrantío a tierras menos feraces. El crecimiento de la demanda en la ciudad influye en los circuitos de producción agropecuarios y en la especialización en determinados predios en los que incide de manera más directa la inversión, las mejora productivas y la gestión. El predominio abrumador de las tierras vitivinícolas no es sorpresivo, pues los propietarios judíos se interesan por el aspecto más comercial de la actividad agraria, estrechamente ligada a las exigencias del mercado. No obstante las cantidades obtenidas de los terrajes puestos en explotación por terceros no tendrían gran entidad reforzando el abastecimiento familiar y dando salida al excedente en los mercados semanales.

Se prefieren los plazos ciertos también llamados terrajes o alcabalas, lo que permite a sus poseedores permanecer atentos a las fluctuaciones del mercado y vigilar estrechamente el trabajo y las mejoras introducidas en sus bienes raíces. Sin embargo, la tendencia a la duración decenal difiere de la tónica que se presenta por ejemplo en las vegas del Jalón y del Jiloca, mucho más productivas que la que nos ocupa ${ }^{283}$. La renta fundiaria no es monetal sino que se prefiere una retribución en especie, con un módulo impositivo más elevado que los treudos perpetuos. La proporcionalidad mantiene valores constantes que oscilan entre $1 / 4$ y $1 / 5$ de la cosecha, con bonificaciones, con lo que se aproximan a la explotación del agro oscense en la primera

\footnotetext{
${ }^{281}$ Cada cahizada equivale a 11.025 varas cuadradas.

${ }^{282}$ Ignacio Jordán de ASSO Y DEL Río, Historia de la economía política de Aragón, Reedición y notas por J. M. Casas Torres, Zaragoza, 1947, p. 26.

${ }^{283}$ En Calatayud tenen una duración media de 3-5 años. Miguel Ángel Motis DoLADER, The expulsion of the jews from Calatayud (1492-1500). Regesta of documents from the Archivo de Protocolos. Sources for the history of the Jews in Spain. $\mathrm{n}^{0}$. 2, The Henk Schussheim Memorial Series, Jerusalem, 1990; y Judios y judeoconversos de la Raya Occidental del reino de Aragón, op. cit.
} 
mitad del siglo XV en que un $50 \%$ se sitúan en $1 / 4$, en torno a un $30 \%$ se cotizan en $1 / 5^{284}$

La detracción entre un $16,6 \%$ y $22 \%$ de media en la producción bruta - a la que habría de deducirse los impuestos, inversiones y diezmos a cargo del arrendatario- obliga a los labriegos a invertir una mayor densidad de trabajo por unidad de superficie para superar el nivel del autoconsumo que le situaría en una nivel de franca precariedad coyuntural, siendo un motor de la productividad del que era el primer beneficiario el propietario a cuyas manos pasaba la tierra al expirar el contrato. Ello daba pie para que fijara en un nuevo período contractual sucesivo una mayor detracción de la cosecha a su favor ${ }^{285}$

En ningún caso el canon percibido supera los excedentes productivos, tras deducir la remuneración del trabajo aplicado y los costes de inversión y explotación ${ }^{286}$. Es legítimo pensar que la tasa se fija a tenor de la presión demográfica y la escased o carestía de la tierra, así como el índice de productividad ${ }^{287}$ y la inversión infraestructural (de donde derivan los años de carencia en el pago). El nivel de renta fundiaria deriva de la productividad del trabajo agrícola y de la propia estructura social.

Las corporaciones y personas jurídicas observan un comportamiento un tanto dispar, aunque lo reducido de la muestra no nos permite extraer conclusiones firmes. La cofradía de zapateros, por boca de su prior Fahim Lavor, firma una carta pública de atreudamiento - un censo enfitéutico-, el 24-IV-1413, a Martin de Olivan, alias Baraguas, vecino de Jaca, un campo próximo al cementerio judío, confrontante con viña del difunto Garcia d'Acomuer, viña de Açach Avingoyos y el fosar, por espacio de 8 años. Además de prevenirle respecto a todo daño que pudiere causar a la finca, se determina el pago anual de 3 cuartales de trigo en la festividad de San

\footnotetext{
${ }^{284}$ Carlos Laliena, Propiedad de la tierra y relaciones de producción en el sistema agrario suburbano de Huesca en el siglo XV, "Argensola", 102 (1989), p. 174.

${ }^{285}$ Jacques JACQUART, La rente foncière, indice conjuncturel?, "Revue Historique", CCLIII (1975), pp. 355-76.

${ }^{286}$ Paulino IRADIEL, Progreso agrario, desequilibrio social y agricultura de transición. La propiedad del Colegio de España en Bolonia (siglos XIV-XV), Bolonia, 1978, p. 369.

${ }^{287}$ Posiblemente los judíos jacetanos abonaban sus tierras con deyecciones orgánicas de origen animal como parece confirmar la donación que Alfonso I hiciera en 1104 a su merino García Ricolse de la mitad del estiércol de los judíos. Ricardo del ARCO Y GARAY, Las juderías de Jaca y Zaragoza, p. 80.
} 
Miguel de Septiembre ${ }^{288}$. Teniendo en cuenta la proporcionalidad que se suele exigir en otros contratos entre el $1 / 5$ y el 1/6 este campo tendría una producción anual en torno a 18 cuartales $^{289}$.

Otra de las corporaciones existentes - la almosna - por medio de sus rectores, el 14-XI-1413, en que atreudan un «plantero» ${ }^{290}$ en Campienzán a Johan de Bergossa y García Bergossa, hijo suyo, vecinos de Jaca ${ }^{291}$, gravándola con un censo de 8 sueldos pagaderos en Todos los Santos. Deberá labrarlo y atender las distintas labores que precise: «xabrir, podar, ligar, cavar, hedier, etc ${ }^{292}$.

Se observa a través de estos dos ejemplos que las colectividades tienen preferencia por fijar un censo estable -indistintamente en especie o monetarizado-y no parciario.

Otro capítulo a estudiar contempla el tráfico de bienes fundiarios. Si bien hemos de decir que el movimiento mercantil de tierras es desesperanzador como para avanzar alguna hipótesis consistente.

El 23-II-1419, Duenya viuda de Fahim Almosnin, y Abram Abenaçaya, físico, y Jamila, matrimonios, venden una viña en Carpuey, limítrofe con otra viña de Menahem Ampifaz, viña de San Francisco, un barranco y una carrera pública. Se tasan en 160 florines de oro pagados por Martin y Johan de Rayça, notario, hijo suyo, ciudadanos de Jaca ${ }^{293}$. Estos viñedos no sólo se dedicaban al cultivo de la uva, la previsible carencia de suelo les obligaba a buscar la máxima productividad asociándola a otros cultivos, como en este caso en que se mencionan los árboles frutales. Evidentemente se trata de regadío pues se consignan las rasas. Por otro lado, la excelencia de la tierra se manifiesta por el precio alcanzado.

El 8-II-1417, Duenya, viuda de Faym Almosnin, vende a Sthevan de Navas y a su mujer, vecino de Jaca, una viña en el término de Guasa, por

\footnotetext{
${ }^{288}$ AHPH, Protocolo 8667, Jaca, 1413, fols. 48-49.

${ }^{289} 1$ cuartal $=7,772$ litros. Pablo LARA IZQUIERDO, Sistema aragonés de pesos y medidas. La metrología histórica aragonesa y sus relaciones con la castellana, Zaragoza, Guara Editorial, 1984, p. 197.

${ }^{290}$ En este caso la nomenclatura plantero es sinonímica de viñedo.

${ }^{291}$ «A los vuestros e toda vuestra generacion».

${ }^{292}$ AHPH, Protocolo 8667, Jaca, 1413, fol. 80 v.

${ }^{293}$ AHPH, Protocolo 8669, Jaca, 1419, fols. 41-43.
} 
200 sueldos $^{294}$. Meses después, el 24 de noviembre, enajena una viña yerma en la Paul de Tarpuey, término de Baros, a Garcia Arrueno y su cónyuge, vecinos de Jaca, por 65 sueldos $^{295}$

El 21-VIII-1413, Azarian Avingoyos, hijo de Sento, vende a Domingo Martinez d'Acenarbe y Oria, mujer suya, vecinos de Jaca, unas eras francas que solían ser parrales, en las eras de la peña de Jaca, que confrontan con eras de San Pedro de Jaca, eras de Guillem d'Aches y la Tallada, por 330 sueldos $^{296}$.

Una operación de préstamo con fianza nos permite averigüar que Abram Lonieto - el 14-XI-1413 - posee un plantero en Puy de Lirio, confrontante con unas carreras públicas, un campo y una viña, desconociéndose la naturaleza exacta de la explotación. ${ }^{297}$ Otra donación entre cónyuges se produce en 1419, en que Açach Avingoyos, hijo de Azarian, judío, le cede a Duenya, además de unas casas en la judería, dos viñas en Soçel, 298. Se cita también una viña de Jehuda Abambrón en el término de Montecillo, en una venta efectuada el 6-III-1414 por María López, viuda de Gil de Aysa ${ }^{299}$.

De cuanto llevamos expuesto se deduce que las pequeñas explotaciones constituyen la base fundamental del sistema productivo agrario local. Los judíos arrendadores son incidentales - la propiedad es total pues no se declaran censos preexistentes - y no muestran tendencia hacia la acaparación de tierras, más bien parecen pequeños propietarios dispersos en unos contornos en que no es posible el macrofundio. Porcentualmente los índices de propietarios son reducidos, aunque no tanto como entre sus correligionarios de Huesca ${ }^{300}$.

Es factible que estas propiedades provengan de la apropiación a campesinos o artesanos insolventes. Hagamos una breve reseña de las que hasta aquí llevamos consignadas:

\footnotetext{
${ }^{294}$ AHPH, Protocolo 8116, Jaca, 1417, fol. 7.

${ }^{295}$ AHPH, Protocolo 8116, Jaca, 1417, fol. $42 \mathrm{v}$.

${ }^{296}$ AHPH, Protocolo 8667, Jaca, 1413, fol. 76 v. -77 v.

${ }^{297}$ AHPH, Protocolo 8667, Jaca, 1413, fol. 84.

${ }^{298}$ AHPH, Protocolo 8669, Jaca, 1419, fols. 23 v.-24.

${ }^{299} \mathrm{AHPH}$, Protocolo 8114, Jaca, 1414, fol. $18 \mathrm{v}$.

${ }^{300}$ Algún historiador calcula para Huesca un $3 \%$ aunque nos parece una cifra excesivamente irrelevante. Carlos Laliena, Propiedad de la tierra y relaciones de producción en el sistema agrario suburbano de Huesca en el siglo XV, p. 147.
} 


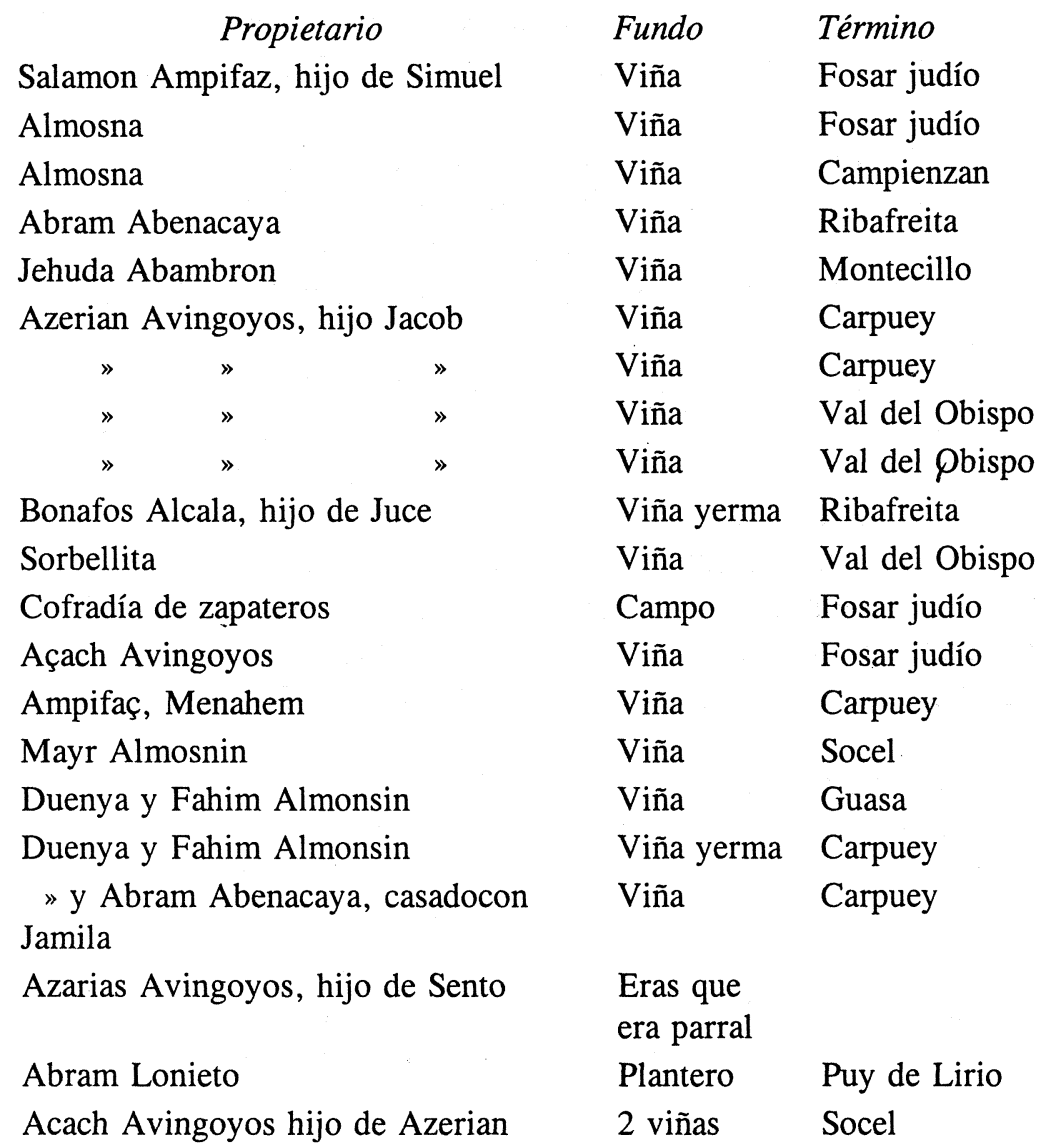

\subsection{El sector comercial y artesanal}

Los protocolos notariales son muy parcos a la hora de informarnos sobre la estructura socio-profesional, -contrariamente a lo que sucederá a fines del siglo ${ }^{301}$ - pues tan sólo hemos podido censar las siguientes 3 zapateros, $3(+2)$ físicos, 2 corredores, 1 cirujano, 2 sastres y 1 sham$\operatorname{mas}^{302}$.

\footnotetext{
${ }^{301}$ Motis, Los judios de Jaca en el siglo XV, op. cit.

${ }^{302} \mathrm{Se}$ identifican en la lista nominativa de la población.
} 
La tipificación de las profesiones ejercidas por los judíos es mínima en unos documentos que persiguen la identificación de los otorgantes - como sujetos físicos y jurídicos-, de ahí que se ponga más énfasis en esclarecer los linajes homónimos conviventes, expresando la línea paternofilial, que no la actividad o situación laboral del interesado. No obstante, y por vías indirectas es posible hacer una somera aproximación a la vida asociativa de los gremios judíos de Jaca.

Una carta pública de atreudamiento formalizada el 24-IV-1413, nos coloca sobre la pista de uno de los gremios judíos de mayor implantación. Se trata de la habura de los zapateros judíos jacetanos, corporación homóloga a la zaragozana ${ }^{303}$. En el documento en cuestión, Fahim Lanor, «prior de la confraria de los judios çapateros», atendiendo al «proveyto de la dita confraria» atreuda a Martin de Olivan, alias Baraguas, vecino de Jaca, un campo próximo al cementerio judío, por un censo anual de 3 cuartales de trigo. El testigo instrumental Salamon Almosnin, es dado pensar que pudiera pertenecer a dicha cofradía ${ }^{304}$. Corrobora esta actuación notarial la existencia de bienes patrimoniales de este tipo de corporaciones, lo que les permite disfrutar de cierta autonomía económica aunque no lograran emanciparse totalmente de la autoridad de rabinos y adelantados que fiscalizan alguna de sus actuaciones.

En ciudades de tipo medio como Jaca se experimenta una decidida tendencia a la proliferación y profundización de las actividades secundarias o artesanales, contribuyendo, junto con la explotación de las materias primas, al incremento del comercio interregional ${ }^{305}$. Este cometido, primordialmente mercantil, excede los estrechos límites del autoconsumo y actúa como centro dinamizador y distribuidor de materias primas, de manera destacada la lana, nutriente de una industria textil notable. De hecho, un

\footnotetext{
${ }^{303}$ Manuel de Bofarull, Colección de Documentos Inéditos del Archivo de la Corona de Aragón. Gremios y Cofradías, vol. XL, Barcelona, 1876, pp. 131-133; Miguel Angel MoTIS DOLADER, Cauces metodológicos para el estudio de las cofradías gremiales judías (haburot) en el Aragón Bajomedieval, "I Jornadas de Metodología de la investigación científica sobre fuentes aragonesas", Zaragoza, 1986, pp. 179-188; María Asunción BLASCO, Instituciones sociorreligiosas judías de Zaragoza (siglos XIV-XV). Sinagogas, cofradías, hospitales, "Sefarad", L (1990), pp. 42-43.

${ }^{304} \mathrm{AHPH}$, Protocolo 8667, Jaca, 1413, fols. 48-49.

${ }^{305} \mathrm{La}$ familia Alnieto, a fines del siglo XIII, era arrendataria del peaje de los puertos de Canfran y Camp d'Alxun. En algunos ejercicios coyunturalmente adversos (me refiero al de 1312) experimentó cuantiosas pérdidas en su explotación. RÉGNÉ, History of the Jews in Aragon, doc. 2961.
} 
factor capital en el enriquecimiento de ciertos sectores de la aljama se obtiene con el préstamo y el comercio de la lana. Los judíos que, como en otras aljamas del reino, tienen la virtud de adaptarse al medio, no desaprovechan las oportunidades que ofrece la explotación y comercialización de esta preciada materia prima.

Los protocolos coetáneos escrituran alguna de estas transacciones. Unas partidas responderán a necesidades de consumo artesanal/familiar y otras comerciales. Dentro del ámbito de los mercaderes tratantes de lana se decantan por la compra con entrega de una fianza o mediante documentos de depósito o comandas con pago antelado. Como preludio referenciamos las transacciones que se han asentado para nuestro período en los protocolos conservados ${ }^{306}$.

-El 30-XII-1409, Garcia Castiedo, vecino de Borau, vende a Baruch Almosnin 400 lanas «una delant otra con sus adobos», a 15 dineros la lana, que se encargará de llevar a Jaca por sus propios medios, en la festividad de San Pedro ${ }^{307}$. Como señal le entrega 20 florines $^{308}$. El monto global se sitúa en 500 sueldos, luego el desembolso anticipado significa el $40 \%$.

-El 30-XII-1409, Garcia Castiedo, Pero Gil y Pero Ximenez, habitantes en Borau, venden al mismo judío 130 lanas a 15 dineros cada lana - pago antelado- que habrán de ser entregados en Jaca en la festividad de San Pedro. Adelanta 95 sueldos $^{309}$.

-El 15-I-1410, Abram Arama, adquiere a Garcia Gavin, habitante en Acumuer, 300 «lanas cabaleras madre con fillo», por 19 dineros la piel, entregadas en Jaca el día de San Pedro, debiendo librar una señal de 300 sueldos. Esta operación se cancela el 10 de enero de $1411^{310}$.

-El 8-IV-1410, Garcia Perez de Latres, señor de Serué, vende a Jacob Avingoyos, hijo de Sento, 300 lanas cabaleras «madre con fillo», por 18,5 dineros la pieza, que habrán de ser llevadas - los portes siempre corren

\footnotetext{
${ }^{306}$ Cuadro ${ }^{\circ}$. 2. Tráfico lanero registrado a través de documentos de compraventa.

${ }^{307} \mathrm{Se}$ celebra el 29 de junio

${ }^{308}$ AHPH, Protocolo 8666, Jaca, 1410, fol. 4 v.

${ }^{309}$ AHPH, Protocolo 8666, Jaca, 1410, fol. 5.

${ }^{310} \mathrm{AHPH}$, Protocolo 8666, Jaca, 1410, fol. 8.
} 


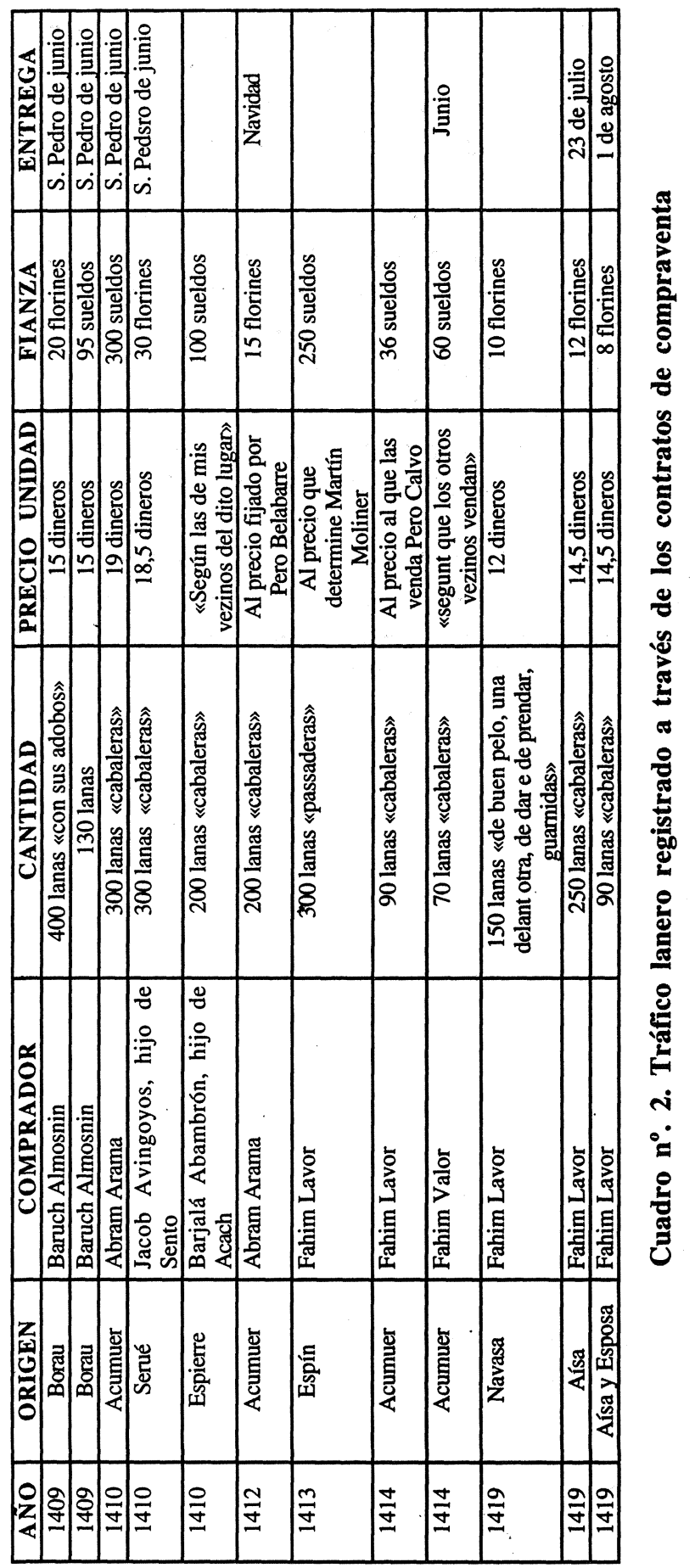


a cargo del vendedor - a Jaca en la fiesta de San Pedro. La operación se cancela el 24 de marzo de $1412^{311}$. La fianza establecida se cifra en 30 florines $^{312} \mathrm{de}$ oro.

-El 23-X-1410, Martín Mayoral, vecino de Ezpierre, vende a Barjala Abambron, hijo de Açach, 200 lanas cabaleras, «segun las de mis vezinos del dito lugar», previo adelanto de 100 sueldos $^{313}$.

-El 29-XII-1412, Gil d'Ayvar y Martín de Belarre, habitantes en el lugar de Acumuer, venden a Abram Arama, judío de Jaca, 200 lanas "cabaleras madre con fillo", al precio que se coticen las de Pero Belabarre en Navidad. Los portes correrán a cargo del vendedor que se compromete a efectuar la entrega en la ciudad de Jaca. El judío paga por adelantado 15 florines de oro ${ }^{314}$.

-El 26-IV-1413, Rodrigo Villacampa, habitante en Espín, vende a Fahim Lanor, 300 lanas «passaderas» al precio que fije Martín Moliner de Biduas con las suyas. Se entregarán en Jaca. Da como señal 250 sueldos. La operación se cancela el 8-IX-1413 ${ }^{315}$.

-El 8-XI-1414, Gil d'Ipas, vecino de Acumuer, vende a Fahim Lanor, 90 lanas cabaleras al precio a que las venda Pero Calvo. Entrega como señal 36 sueldos y promete darle dos lanas bellas ${ }^{316}$.

-El 5-X-1414, Gil de Petro Sanz, vecino de Acumuer, vende a Faym Lanor, hijo de Juce, 70 lanas cabaleras, «segunt que los otros vezinos vendan». Habrán de ser entregadas en junio. Como adelanto paga 60 suel$\operatorname{dos}^{317}$.

-El 25-X-1419, Martín de Garassa, habitante en Navasa, vende a Fahim Lavor, judío de Jaca, 150 lanas «de buen pelo, una delant otra, de dar e de prendar guarnidas», estipulándose un precio de 12 dineros por piel. Como señal adelanta 10 florines de oro ${ }^{318}$.

\footnotetext{
${ }^{311}$ AHPH, Protocolo 8666, Jaca, 1410, fol. 29.

${ }^{312} 1$ florín $=10$ sueldos. $•$

${ }^{313}$ AHPH, Protocolo 8666, Jaca, 1410, fol. 66.

${ }^{314} \mathrm{AHPH}$, Protocolo 8667, Jaca, 1413, fol. 2 v.

${ }^{315} \mathrm{AHPH}$, Protocolo 8667, Jaca, 1413, fol. $41 \mathrm{v}$.

${ }^{316} \mathrm{AHPH}$, Protocolo 8668, Jaca, 1414, fol. $98 \mathrm{v}$.

${ }^{317} \mathrm{AHPH}$, Protocolo 8114, Jaca, 1414, fol. $44 \mathrm{v}$.

${ }^{318} \mathrm{AHPH}$, Protocolo 8669, Jaca, 1419, fols. $146-146 \mathrm{v}$.
} 
-El 8-XI-1419, García y Gil d'Aysa, hermanos, habitantes en Aísa, venden a Fahim Lavor, 250 lanas cabaleras, tasadas a 14,5 dineros la lana $^{319}$. En contraprestación les libra 12 florines de oro. Esta operación se da por concluida el 23-VII-1420.

-El 14-XI-1419, Blasco Gil López, habitante en Aisa, y Gil d'Usposa, habitante en Esposa, venden a Fahim Lavor, 90 lanas cabaleras al mismo precio que las anteriores, haciéndoles entrega por adelantado de 8 florines de oro. La operación se cancela el 1-VIII-1420 $0^{320}$.

Aunque más adelante incidiremos sobre los actores y la procedencia geográfica de la lana, hagamos unas breves observaciones sobre los contratos a los que hemos pasado revista. El pago se fracciona con un anticipo y un poscipo, es decir, se entrega una cantidad a cuenta y a la recepción de la lana se hace efectivo la cantidad restante. La fianza antelada ni desciende del $40 \%$ del total del pedido ni supera el $75 \%$ del volumen bruto.

Los pedidos` se realizan en más de las tres cuartas partes en las estaciones más frías, en otoño tardío y en el invierno, concentrándose en el trimestre octubre-diciembre. Las entregas - salvo excepciones- se pactan en los meses de junio-julio y agosto, con claro predominio del primero y en especial de la festividad de San Pedro, que en sí misma condensa la mitad de los libramientos, lo que no es una casualidad pues en esta fecha tiene lugar la feria jacetana. En todos los contratos se preceptúa que los portes serán pagados y no debidos, es decir, de cargo del vendedor, aunque éstos se incluían en el precio global de las materias primas.

El precio oscila entre los 12 dineros la piel hasta los 19 dineros. No queda nada claro el tipo de lana contratada pero sí parece que la denominada "cabalera» ${ }^{321}$ es la de mejor calidad, destacando por su finura, excelente longitud, probada resistencia, buen tacto y por ser completamente blanca o ligeramente amarillenta. Procede de la espalda y las partes laterales del tronco. En la escala inferior se encuentra la "pasadera» que registra tasas inferiores, en correspondencia con los precios, que nunca se valoran por debajo de los 14,5 dineros. Se citan también los añinos, término con que se designa a la lana procedente de los corderos de la primera esquila. Los

\footnotetext{
${ }^{319} \mathrm{AHPH}$, Protocolo 8669 , Jaca, 1419 , fol. $158 \mathrm{v}$

${ }^{320} \mathrm{AHPH}$, Protocolo 8669, Jaca, 1419, fol. 162.

${ }^{321}$ Esta clasificación no es gratuita, por ejemplo, en algunos documentos el escriba apunta por error "cabaleras", tachándolo inmediatamente y colocando en su lugar el término de «passaderas». AHPH, Protocolo 8 669, Jaca, 1419, fol. 14.
} 
denominados «largos» poseen una longitud muy próxima a las fibras del ganado adulto, mientras que los «cortos» se obtienen de vellones de corderos jóvenes ${ }^{322}$.

En numerosas operaciones, por el contrario, el precio se deja al arbitrio del momento en que se verifique el trasquileo «segunt que los otros vezinos vendan» o a criterio de ciertas personas - Martin Moliner, Pero Calvo- que, según todos los indicios, contaban con extensas cabañas ovinas lo que les colocaba en una posición privilegiada para regularizar los precios de mercado.

En los valles jacetanos se pastorean diversos ecotipos de la raza ovina aragonesa. La ansotana o chesa, originaria del valle pirenaico de Ansó, se encuentra de igual modo en Hecho y el Aragón, extendiéndose por el Este hacia Canfranc, junto con la Churra Tensina - en el valle del Tenaconstituyen históricamente la base de la trashumancia secular. Durante el verano («estiva») aprovecha los abundantísimos pastos de altura de la cordillera pirenaica entre los 1.600 y 2.500 metros de altitud.

El primer subtipo es de vellón más abierto y lana más larga como respuesta a un medio húmedo, formando parte del grupo entrefino pirenaico. Es de color blanco con ausencia total de pigmentación en piel y pelo ${ }^{323}$. Aunque sean datos actuales podemos utilizar como cifra referencial que esta raza ofrece una producción de 1,5-1,8 Kgr, de lana en las ovejas y de 2 a $3 \mathrm{Kgr}$. en los machos ${ }^{324}$. Por último, la churra tensina puebla el valle oscense de Broto y Tena, del que toma su nombre, especialmente en la parte alta de la cuenca del río Gállego, siendo calificada por los especialistas de «nicho ecológico» pues todas las razas aragonesas no poseen ningún rasgo en común con ella. Constituye la base de la vida socioeconómica del Alto Aragón familiar a través de su producción de carne, leche-queso, lana y piel. Posee una fibra de lana de unos $40 \mathrm{cms}$., siendo su producción lanera de 1,5-2 Kgr, en las hembras y 2,5-3 en los machos ${ }^{325}$.

Empero, el tráfico lanero se pone de manifiesto también a través de los contratos comanditarios que persiguen dos fines muy distintos: los

\footnotetext{
${ }^{322}$ Antonio SÁNChez Belda y María del Carmen SÁnChez Trujillano, Razas ovinas españolas, Ministerio de Agricultura, Pesca y Alimentación, Madrid, 1986, p. 217.

${ }^{323}$ Isidro LASIERRA, La ganadería aragonesa, Zaragoza, p. 31.

${ }^{324}$ LASIERRA, La ganadería aragonesa, p. 33.

${ }^{325}$ LASIERRA, La ganadería aragonesa, pp. 35-36.
} 
expedidos por mercaderes - de cuantías similares a los que hemos visto supra- y los que obedecen a un nivel distinto de transacción, y suelen contratar pequeñas cantidades con fines artesanales - provisión de materias primas de los gremios de tejedores, sastres, curtidores o zapateros- ${ }^{326}$. Objetivémoslos cronológicamente:

-El 23-II-1410, Juce Almosnin, hijo de Jahuda, Juce Almosnin, hijo de Mayr, reciben en comanda de Gil de Carastue, menor, vecino de Jaca, una carga de lana fina ${ }^{327}$, ensacada y marchante ${ }^{328}$.

-El 25-III-1410, Jacob Abambron, alias de Sos, y Mose Abambron, hijo suyo, comanda de Salvador de Generes, de Jaca, una carga de lana lanada blanca ${ }^{329}$.

-El 5-V-1410, Azerian Avingoyos, hijo de Sento, obtiene en comanda de Gil de Carascue, menor, vecino de Jaca, 5 quintales de lana «blanca, lanada, fina y merchant». Implica una elaboración previa por parte del artesano fruto quizás de su entrega y el pago de su trabajo. Pone en garantía un huerto franco en la judería, renunciando a los 30 días que le concede la fianza del fuero ${ }^{330}$.

-El 24-III-1413, Bonafos Alcala, hijo de Juce, recibe en comanda de Guiralça de Thena, viuda de Miguel de Padules, una bala de lana «blanqua lanada», ponderada en 19 docenas ${ }^{331}$.

-El 29-XII-1413, Gil de Petro Sanz, habitante en Acumuer, obtiene en comanda de Juda Avingoyos, hijo de Azarian, 100 lanas cabaleras ${ }^{332}$.

-El 14-I-1414, Saçon Alcala, hijo de Abram, y Açach Larros, hijo de Junez, comanda de Salvador de Generes, hijo de don Ramon, mercader, ciudadano de Jaca, una carga de lana lavada ${ }^{333}$.

\footnotetext{
${ }^{326}$ Cuadro $n^{\circ}$. 3. Tráfico lanero consignado en los contratos comanditarios.

${ }^{327}$ Una carga equivale a 4 quintales y 24 libras. A partir de ahora cuando no se haga constar la igualdad se mantendrá estable.

${ }^{328} \mathrm{AHPH}$, Protocolo 8112 , Jaca, 1410, fols. 11-11 v. Es cancelada.

${ }^{329} \mathrm{AHPH}$, Protocolo 8112 , Jaca, 1410, f́l. 15.

${ }^{330} \mathrm{AHPH}$, Protocolo 8666, Jaca, 1410, fols. 43 v.-35.

${ }^{331} \mathrm{AHPH}$, Protocolo 8667, Jaca, 1413, fol. 26.

${ }^{332} \mathrm{AHPH}$, Protocolo 8668, Jaca, 1414, fol. 3. Sin cancelar.

${ }^{333} \mathrm{AHPH}$, Protocolo 8668, Jaca, 1414, fol. 15. Cancelada.
} 


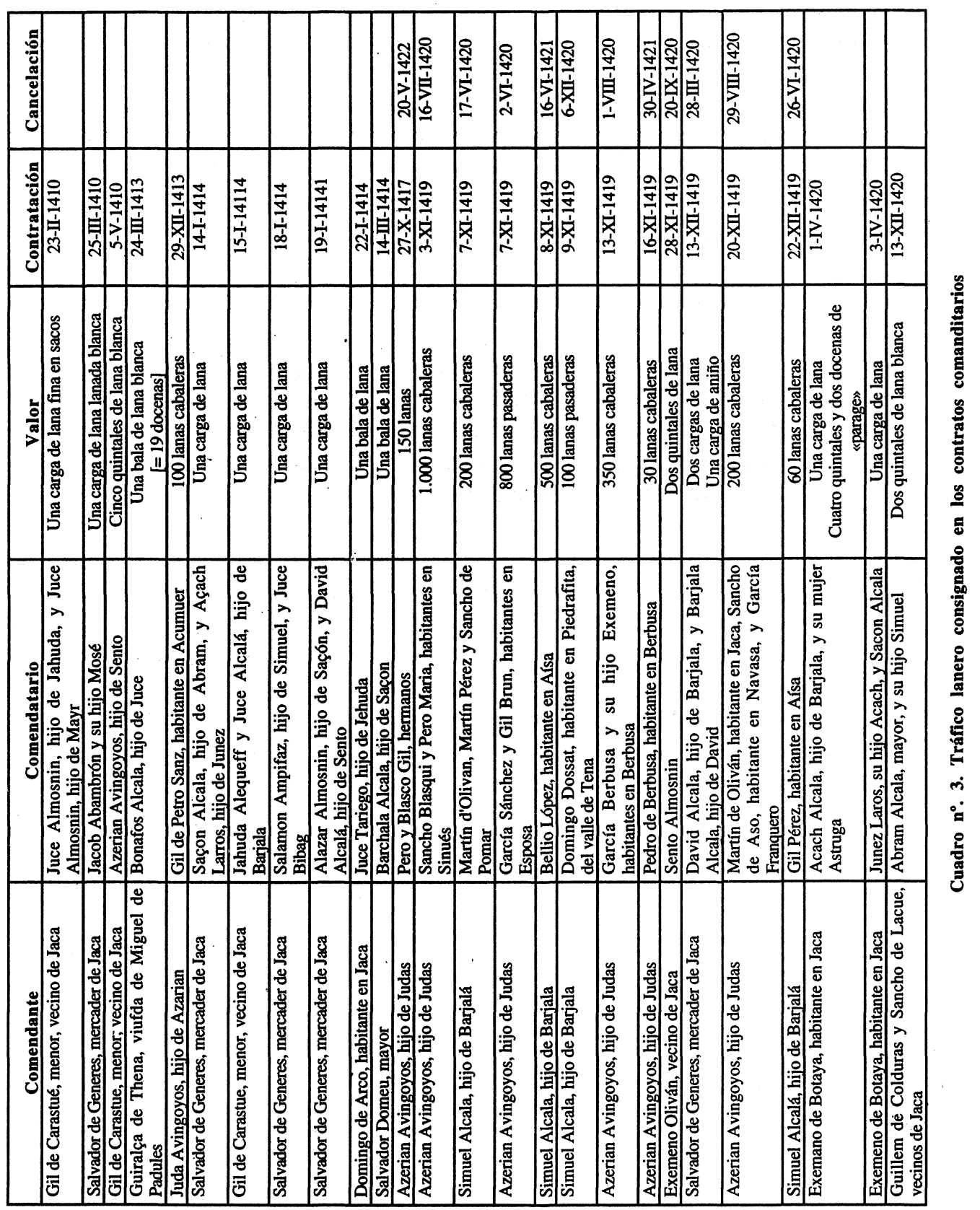


-El 15-I-1414, Jahuda Alequeff y Juce Alcala, hijo de Barjala, reciben en comanda de Gil de Carastue, vecino de Jaca, una carga de lana lanada fina y mercadera, de 4 quintales de peso ${ }^{334}$.

-El 18-I-1414, Salamon Ampifaz, hijo de Simuel, y Juce Bivag, en una comanda suscriben 260 sueldos y 1 carga de lana -previsiblemente la lana era el rédito anual- de Salvador de Genere. Asiste a la transacción Barjala Alcala, hijo de Juce, corredor público ${ }^{335}$.

-El 19-I-1414, Alatzar Almosnin, hijo de Saçon, y David Alcala, hijo de Sento, obtienen en depósito de Salvador de Generes, mercader, una carga de lana ${ }^{336}$.

-El 22-I-1414, Juce Tariego, hijo de Jehuda, de Domingo d'Arco, habitante en Jaca, una bala de lana lanada fina, de un peso de 2 quintales $^{337}$.

-El 14-III-1414, Barchala Alcala, hijo de Sazon, obtiene en comanda de Salvador Domeu, mayor, una bala de lana fina de «parage» lavada y marchante ${ }^{338}$.

-El 27-X-1417, Azerian Avingoyos, hijo de Judas, encomienda a Pero Gil y Blasco Gil, hermanos, 150 lanas. Esta comanda será cancelada el 20 de mayo de $1422^{339}$.

-El 3-XI-1419, Sancho Blasqui y Pero Maria, habitantes en Sirués, reciben de Azarian Avingoyos, hijo de Judas, 1.000 lanas cabaleras -el calibre de esta operación queda reflejada por el hecho de que en las compraventas citadas con anterioridad tan sólo en una ocasión se adquieren más de 300 pieles, situándose en una media de las 150 -, siendo cancelada el 16 de julio de $1420^{340}$.

\footnotetext{
${ }^{334}$ Cancelada. AHPH, Protocolo 8668, Jaca, 1414, fol. 15 v.

1 quintal $=50,52 \mathrm{Kgrs}$.

1 libra $=350,835$ gramos. Existe la libra alizaria o carnicera de 36 onzas, tres veces superior en peso, aunque no es este el caso. LARA, Metrología aragonesa, p. 196.

${ }^{335}$ AHPH, Protocolo 8668, Jaca, 1414 , fol. 19 v.

${ }^{336}$ AHPH, Protocolo 8668, Jaca, 1414, fol. 20.

${ }^{337}$ AHPH, Protocolo 8668, Jaca, 1414, fol. 20 v.

${ }^{338} \mathrm{AHPH}$, Protocolo 8114 , Jaca, 1414, fol. $19 \mathrm{v}$.

${ }^{339}$ AHPH, Protocolo 8669, Jaca, 1419, fol. 147.

${ }^{340} \mathrm{AHPH}$, Protocolo 8669, Jaca, 1419, fol. 156 v.
} 
-El 7-XI-1419, Martín d'Olivan, Martín Pérez y Sancho de Poma, habitantes en el lugar de Barahués, recibe en comanda de Simuel Alcala, hijo de Barjala, 200 lanas cabaleras que cancelará el 17 de junio de $1420^{341}$.

-El 7-XI-1419, García Sánchez d'Asposa y Gil Brun, hijo de Brun Domingo, habitante en Asposa, obtienen en comanda de Azarian Avingoyos, 800 lanas pasaderas. Cancelada el 2 de junio de $1420^{342}$.

-El 8-XI-1419, Bellio López, habitante en Aísa, obtiene en comanda de Simuel Alcala, hijo de Barjalá, 500 lanas caballeras. Son canceladas el 16 de junio de $1421^{343}$.

-El 9-XI-1419, Domingo Dossat, habitante en Piedrafita de la Val de Tena, recibe en comanda de Simuel Alcala, hijo de Barjalá, 100 lanas cabaleras. Se cancela el 6 de diciembre de $1420^{344}$

-El 13-XI-1419, García Berbusa y su hijo Exemeno, habitantes en Berbusa, obtienen en comanda de Azarian Av́ingoyos, hijo de Judas, 350 lanas cabaleras. Es cancelada el 1 de agosto de $1420^{345}$.

-El 16-XI-1419, Pedro de Berbusa, habitante en Berbusa, recibe encomendado de Azarias Avingoos, hijo de Judas, 30 lanas cabaleras. Es cancelada el 30 de abril de $1421^{346}$.

-El 28-XI-1419, Sento Almosnin, recibe en comanda de Exemeno Olivan, vecino de Jaca, 2 quintales de lana. Es cancelada el 20 de septiembre de $1420^{347}$.

-El 13-XII-1419, David Alcala, hijo de Barjala, y Barjala Alcala, hijo de David, reciben en comanda de Salbador de Generes, mercader, 2 cargas de lana y 1 carga de añino lavado. Cancelada el 28 de marzo de $1420^{348}$.

-El 20-XII-1419, Martín de Olivan, habitante en Jaca, Sancho d'Aso, habitante en Navasa, y García Franquero, habitante en Javierre,

\footnotetext{
${ }^{341}$ AHPH, Protocolo 8669, Jaca, 1419, fol. 157 v.

${ }^{342}$ AHPH, Protocolo 8669, Jaca, 1419, fol. 158.

${ }^{343}$ AHPH, Protocolo 8669, Jaca, 1419, fol. 158.

${ }^{344} \mathrm{AHPH}$, Protocolo 8669, Jaca', 1419, fol. 161.

${ }^{345} \mathrm{AHPH}$, Protocolo 8669, Jaca, 1419, fol. $161 \mathrm{v}$.

${ }^{346} \mathrm{AHPH}$, Protocolo 8669, Jaca, 1419, fol. $162 \mathrm{v}$.

${ }^{347}$ AHPH, Protocolo 8669, Jaca, 1419, fol. 172.

${ }^{348} \mathrm{AHPH}$, Protocolo 8669, Jaca, 1419, fol. 176 v.
} 
obtiene en comanda de Azarias Avingoyos, habitante en Jaca, 200 lanas cabaleras. Es cancelada el 29 de agosto de $1420^{349}$.

-El 22-XII-1419, Gil Pérez, habitante en Aísa, obtiene en comanda de Simuel Alcala, hijo de Barjalá, 60 lanas cabaleras. Es cancelada el 26 de junio de $1420^{350}$.

-El 1-IV-1420, Açach Alcala, hijo de Barjala, y Astruga su mujer, obtienen en comanda de Exemeno de Botaya, habitante en Jaca, una carga de lana fina que pesa 4 quintales y 2 docenas «parage, lanada y marchant», habrá de pagarle el 1 de agosto ${ }^{351}$.

-El 3-IV-1420, Junez Laros y Sazon Alcala y Açach Laros, hijo de Junez, comanda del mismo una carga de lana ${ }^{352}$.

-El 13-XII-1420, Abram Alcala, mayor, y Simuel Alcala, hijo comanda de Guillem de Colduras y Sancho de Lacue, vecinos de Jaca, reciben 2 quintales de lana blanca fina lanada, neta y mercadera ${ }^{353}$.

Teniendo en cuenta ambas nóminas podemos continuar con nuestras digresiones. Prosigamos con las partes contratantes judías. Contamos con indicios razonables que apuntan a la existencia de judíos capitalistas que ejercen la función de mercader-patrón-suministrando la materia prima que más adelante los compromitentes han de adobar - curtir - o semi-elaborar para ulteriormente entregarlas para su comercialización a aquél que se las había entregado, cobrando, eso sí, por el trabajo invertido. También es posible que actúen como mayoristas dominando cierta cuota de mercado y de los canales de distribución comercializándolo a almacenistas.

Observemos que en estos circuitos participan unos judíos muy selectivos - somos conscientes de la exigüidad de los datos y por tanto de lo sesgado de su cuantificación-. Estos mismos hebreos se integrarán entre aquéllos que ejercen el préstamo con más intensidad, no olvidemos que la lana ofrecía uno de los mayores márgenes de beneficios mercantiles superiores a los productos del campo:

1. Simuel Alcala, hijo de Barjala

860 lanas

2. Baruch, Almosnin

530 lanas

\footnotetext{
${ }^{349}$ AHPH, Protocolo 8669, Jaca, 1419, fol. 181.

${ }^{350}$ AHPH, Protocolo 8669, Jaca, 1419, fol. 182.

${ }^{351}$ AHPH, Protocolo 8724, Jaca, 1420, fol. 11.

${ }^{352} \mathrm{AHPH}$, Protocolo 8724, Jaca, 1420, fol. $11 \mathrm{v}$.

${ }^{353}$ AHPH, Protocolo 9898, Jaca, 1420, fol. 39.
} 
3. Abram Arama

4. Jacob Avingoyos, hijo de Sento

5. Juda Avingoyos, hijo de Azarian

6. Barjala Abambron, hijo de Açach

7. Azerian Avingoyos, hijo de Juda

8. Fahim Lavor

$\mathrm{Si}$ nos atenemos a su dispersión geográfica obtenemos cierto equilibrio en las fuentes de aprovisionamiento, concentrados en los núcleos de contratación de un gran número de personas que al amparo de su comercio, resuelven su vida. Son localidades pequeñas, focos de una región ganadera, donde se reune el ganado para el esquileo o lugares de donde arrancan las rutas de transporte, Se centran, casi en tu totalidad, en el valle de Aísa, Canfrán y Tena (ríos Aragón y Gállego), donde existe una alta densidad de reses del morfotipo ansotano o cheso y churra tensina, subrazas o variedades esenciales en la trashumancia ${ }^{354}$ :

$\begin{array}{lr}\text {-Acumuer } & 1.000 \text { lanas } \\ \text {-Aísa } & 855 \text { lanas } \\ \text {-Berbus } & 380 \text { lanas } \\ \text {-Borau } & 530 \text { lanas } \\ \text {-Espierre } & 200 \text { lanas } \\ \text {-Espín } & 850 \text { lanas }+30 \text { kgrs. } \\ \text {-Esposa } & 66,5 \text { lanas } \\ \text {-Javierre } & 286,5 \text { lanas } \\ \text {-Navasa } & 100 \text { lanas }+24 \text { kgrs. } \\ \text {-Piedrafita } & 300 \text { lanas }+24 \text { kgrs. } \\ \text {-Serué } & 1.000 \text { lanas } \\ \text {-Sinués } & \text { - }\end{array}$

Los pequeños artesanos, frente a los mercaderes, compran montantes poco elevados, por su escasa capacidad de capitalización y sus carencias monetarias líquidas. Las cuantías contratadas oscilan entre una bala de 2 quintales - 101,04 $\mathrm{kgr}$ - y una carga de 206,29 $\mathrm{kgr}-4$ quintales y 24 libras-. Dicho de otro modo, se compran entre $100(38,5 \%)$ y 200 kgrs. (54\%) de lana y sólo en una ocasión se duplica esta última cantidad, lo que podría llevarnos a considerar que esta es la cuota de materia prima - la lana

\footnotetext{
${ }^{354}$ Mapa $n^{\circ}$. 1. Procedencia de la lana comercializada por los judíos de Jaca en el primer tercio del siglo XV.
} 


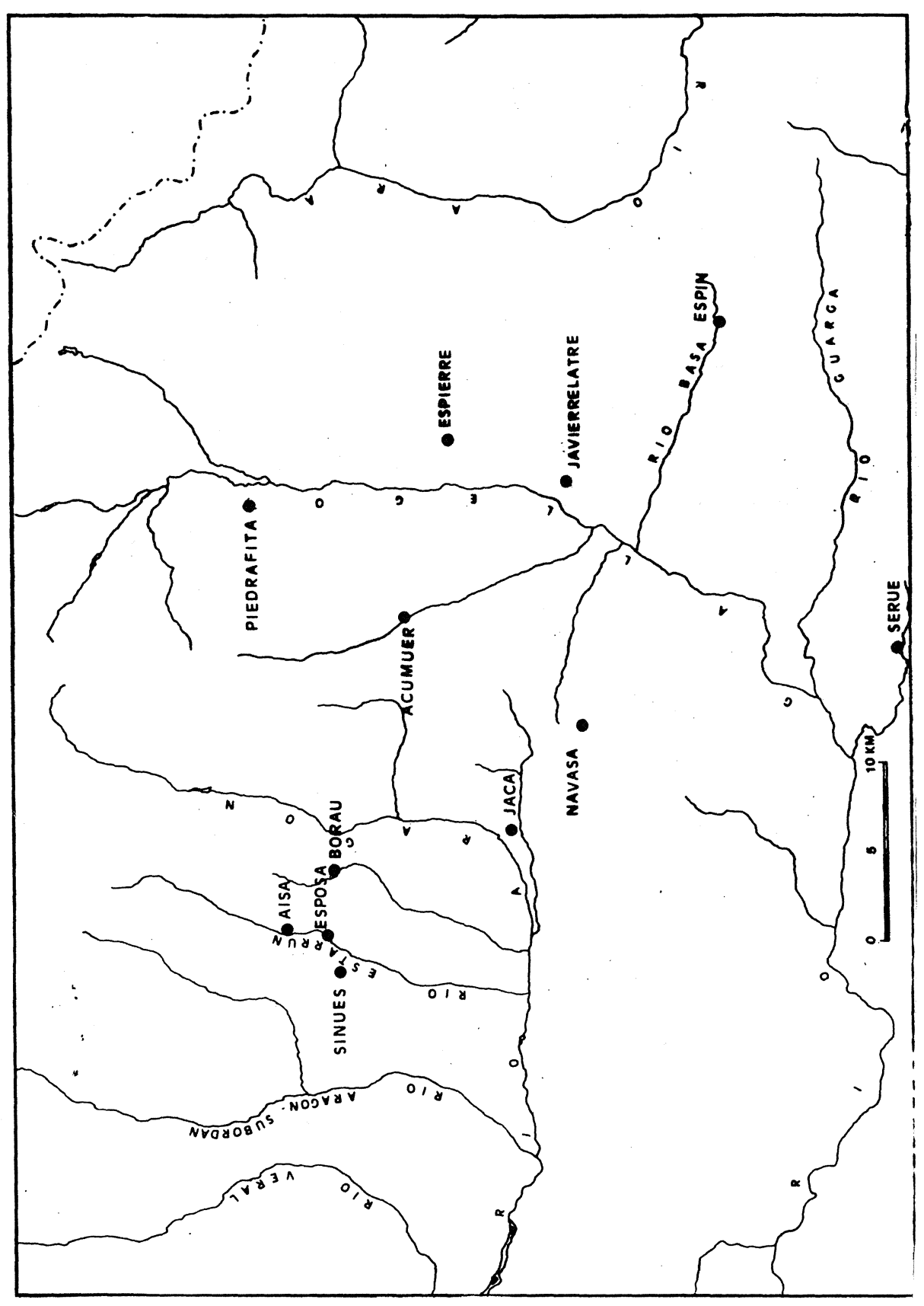


se pacta siempre cruda - empleada por una microunidad de producción en una campaña. La lana de este ganado trashumante posee la virtud de tener mucho estambre, con lo que frecuentemente se obtiene en el siglo XVIII de cada arroba entre 22 y 24 iibras, siendo muy apreciada para tejidos estambrados 355 .

Obsérvese que son los comendatarios de pequeños contingentes de lana son judíos. Si todos los suscriptores tuvieran relación con la textura de la lana o su elaboración en alguno de sus estadios, como es de suponer, la manufactura de esta materia prima debió constituir una de las principales fuentes de riqueza y ocupación socio-profesional de la clase media judía como se cofirma en el último tercio de la centuria. Nótese, nuevamente, la dispersión de estos pequeños artesanos y las asociaciones ${ }^{356}$ que se entretejen en el momento de concertar las cantidades de lana requerida:

Jacob Abambron + Mose Abambron, hijo de Jacob

Açach Alcala, hijo de Barjala, y Astruga

Juce Almosnin, hijo de Jehuda + Juce Almosnin, hijo de Mayr

Azerian Avingoyos, hijo de Sento

Jehuda Alequef + Juce Alcala, hijo de Barjala

Abraham Alcala + su mujer + su hijo Simuel

Barchala Alcala, hijo de Saçon

Bonafos Alcala, hijo de Juce

David Alcala, hijo de Barjala y Barjala Alcala, hijo de David

Saçon Alcala, hijo de Abraham + Açach Larros, hijo de Junez

Sento Almosnin

Alazar Almosnin, hijo de Saçon + David Alcala, hijo de Sento

Salamon Ampifaz, hijo de Simuel + Juce Bibaz

Junez Laros + su hijo de Açach + Saçon Alcalá

Juce Tariego, hijo de Jehuda

Los proveedores son todos cristianos y jacetanos, figurando alguno de - ellos esplícitamente como mercader. Por su número y montante computado individuamente no se aprecian tendencias monopolísticas acusadas aunque Gil de Carastué o Salvador de Generes concentren en su haber un $50 \%$ de las transacciones. Los restantes más que profesionales laneros

\footnotetext{
${ }^{355}$ En 1776 se censaban 202.545 cabezas, lo que es ligeramente inferior al censo de 1788 en que se calcula una producción de 30.635 arrobas de lana extraídas de 240.000 reses. Asso Y DEL Río Historia de la economía política de Aragón, p. 30.

${ }^{356} \mathrm{Se}$ significa con el símbolo (+)
} 
parecen ser productores autónomos o propietarios de pequeñas cabañas ovinas cuyos excedentes comercializan al margen de los centros de distribución consolidados. En este supuesto se encontrarían la viuda de Miguel de Oadules, Domingo de Arco, Salvador Dormer, Exemeo Oliván, Exemeno de Botaya. Se llegan incluso a asociarse par el libramiento de dos quintales de lana Guillem de Colduras y Sancho de Lacue.

Gracias a la estructura comanditaria podemos averiguar, en un elevado número de contratos, el plazo de amrotización. La contratación que, como avanzábamos párrafos más arriba, se concentraba en el período final del año (noviembre-diciembre), se gira a una media de 8 ó 9 meses ${ }^{357}$.

Las fábricas de lana se establecieron a principios del siglo $\mathrm{XIII}^{358}$. En esa centuria -en 1218 para ser exactos- un privilegio de Jaime I, ante el hecho de que los fabricantes de paños residentes fuera de la ciudad llevaban sus piezas a adobarlas allí y batanarlas, mandó que no se permitieran estas operaciones sino en paños tejidos dentro de la ciudad y que nadie pudiera comprar piezas en crudo o sin teñir sino a fabricantes de Jaca ${ }^{359}$ - presupuesto que se cumple a plena satisfacción entre la población judíaEsta medida proteccionista si bien en un comienzo robusteció su industria, a la postre la hizo languidecer ante la ausencia de competencia.

En el siglo XV, la fábrica de paños era pujante como resultado del comercio que se hacía de esta materia prima, siendo muy conocidas las manufacturas de chamelotes o barraganes azulados. Los fogajes de la zona son testigos elocuentes de la introducción de paños franceses - el Conducy británicos ${ }^{360}$. Recordemos que, desde 1249 , podían teñir y hacer teñir en

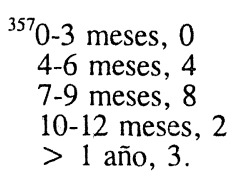

${ }^{358}$ ASSO Y DEL Río, Historia de la economía política de Aragón, p. 130.

${ }^{359}$ D.D. SANGORRÍN Y DiEST-GARCÉs, El libro de la Cadena de Jaca, doc. 9 pp. 237-46. Recientemente, Rosa María BANDRÉS SÁNCHEZ-CRUZAT publica La legislación real de 1063 a 1323, recogida en El libro de la Cadena del Concejo de Jaca, "Estudios en recuerdo de la profesora Sylvia Romeu Alfaro", I, Universitat de València, 1989, pp. 63-70, sin ninguna aportación destacable.

${ }^{360} \mathrm{ADZ}$, Taulas de Comercio, Ms. 664, 1444-45 \& Leg. 652, 1446-47.

Manuel Alvar, Documentos de Jaca (1362-1502). Estudios lingüisticos, "Archivo de Filología Aragonesa", X-XI (1958-59), pp. $195-276$ y Lexicografía medieval: el peaje de Jaca de 1437, en "Estudios dedicados a Menéndez Pidal", II, Madrid, 1951, pp. 41-90. 
sus casas y en la caldera o tintorería real en todos los colores que desearen, sin restricciones, como venía sucediento en Huesca y Lérida ${ }^{361}$.

La abundancia de lana favorece una incipiente industria textil doméstica. En algunos contratos sale a relucir alguna de estas muestras, como el 5-XII-1410 en que Sento Alcala, alias Carido, y sus hijos Saçon y Mahir - la unidad familiar es unidad de producción y reproducciónobtienen en depósito de Exemeno de Quarastue, habitante en Jaca, 60 «codos de sarpillera merchant ${ }^{362}$. El contrato se cancela el 20-VII-1411, cuando probablemente entregaran al cristiano el tejido ya confeccionado. El 1-VII-1414 ${ }^{363}$, Pero de Marcos, vecino de Sallent, jura pagar a Bonafos Alcala, hijo de Juce, 12 florines de oro el 1 de agosto por «un drapo palmella cardeno claro gasconil», con lo que está remunerando la textura de este paño realizada por el tejedor judío.

La ganadería caballar - aunque a mucha distancia de la vacuna y la ovina-tenía entidad propia, llegándose alquilándose las yeguas para su apareamiento y monta. Este es el caso que se registra el 1-V-1413 cuando Azerian Avingoyos, hijo de Jacob, da a Pero Sanchez de Biscarra, habitante en Grazanueple, una yegua por 7 años, debiendo hacerle entrega de la mitad de los potrillos a que hubiera lugar ${ }^{364}$.

Los mulos, por su especial porte como animales de tiro y de transporte son objeto de enejenación. Uno de los judíos más adinerados -Azarian Avingoyos - comprará el 12-IV-1413 a Andreu d'Iguaçar, vecino de Baris, un mulo de pelo negro por el que paga la nada desdeñable cifra de 14 florines $^{365}$.

Ignoramos la implantación económica de la explotación maderera pues nada nos dicen al respecto las fuentes, salvo si exceptuamos algunos Contratos de «tallar fusta» que sí se conservan para principios de siglo ${ }^{366}$.

${ }^{361}$ D. D. SANGORRÍN y DiEST-GARCÉS, El libro de la Cadena de Jaca, doc. 35 pp. 407-408.

${ }^{362} \mathrm{AHPH}$, Protocolo 8666, Jaca, 1410, fol. 69.

${ }^{363}$ AHPH, Protocolo 8668, Jaca, 1414, fol. 63.

${ }^{364}$ AHPH, Protocolo 8667, Jaca, 1413, fol. 52.

${ }^{365}$ AHPH, Protocolo 8667, Jaca, 1413, fol. 41.

366" Avinençia de tallar fusta. Eadem die que yo, Pero Bisearra, menor de dias, habitant en Baros, prometo e me obligo con la present carta a vos Mosse Babo, judio, habitant en la ciudat de Jacca, tallar e aduzir a mis propias missiones a vuestra casa la fusta infrascripta, la qual fusta yes, segunt se sigue primerament VI tiranz de dozena rasa scuaryadas e de la grossaria e ampleza que son las de Jacobon o mas, precio cadauna dos sueldos VII dineros. Item mas, IIII ${ }^{\circ}$ otros tirantes de $\mathrm{X}^{\mathrm{a}}$ rasa scuayradas e tan amplas e tan grossas como las de suso ditas, precio 


\subsection{El sistema crediticio}

El préstamo en su sentido más puro se encuadra dentro de un tipo documental muy concreto: el deudo. En él se declara su propósito con una fórmula clara e inequívoca: «Nos... ensemble e cadauno de nos por si e por el todo atorgamos que devemos dar e pagar a vos... judio de la ciudat de Jaca, prestados por vos a nos aquella el present dia al mandamient del rey entro el dia de...»".

El capítulo más cercano al tráfico de bienes y servicios -el anterior lo es de capitales - es la comanda, donde se pueden ocultar sin dificultad operaciones crediticias - en definitiva transacciones económicas donde no se entrega un precio cierto en el acto como contraprestación por un bien adquirido como es el caso de la compraventa, entraña fiducia- pero que ésta explícitamente no se declaran. De hecho, los deudos desaparecerán tras la disputa de Tortosa, mientras que en los años anteriores se empleaban ambos. Por ello haremos dos salvedades - que en ocasiones no responderan enteramente a la realidad pero que son muy útiles como categorías intelectuales en la comprensión de la realidad económica - el préstamo -o tráfico de dinero fiduciario- y el de bienes y servicios.

La parcela es cubierta sólo por un puñado de jưíos, aquéllos que forman parte de la casta de los mercaderes, y el resto que no tiene capacidad suficiente ni siquiera para negociar con pequeñas partidas.

Las necesidades de algunos prestatarios puede llevarles a enajenar temporalmente los medios de producción, como el matrimonio Bernard d'Anyanyo y Oria, vecinos de Jaca quienes venden a Azarian Avingoyos, hijo de Judas, un molino trapero y las propiedades adyacentes (una acequia con «agua corrient», una viña y un campo), en el término de Radamallos cerca de Puente Seco, el 26-IX-1419, por 480 sueldos $^{367}$.

todos quatro VII sueldos. Item mas, dos solares de cada XVII ${ }^{\mathrm{a}}$ rasa precio entramos VII sueldos e que sian segunt que los de Domingo Dorant e a conocimiento suyo. E prometo e me obligo yo dito Pero Bisquarra aver aduzir en mis propias missiones, segunt dito yes de suso a vuestra casa la dita fusta el dia e fiesta de Santa Cruz de mayo primera vinient etc. E yo dito Mosse Babo, prometo e me obligo dar e pagar a vos dito Pero Biscarra los precios sobreditos de toda e de cadauna la dita fusta entre vos e mi composado e avenido etc.". AHPH, Protocolo 8664, Jaca, fol. 3. 9.I.1407.

${ }^{367}$ AHPH, Protocolo 8669 , Jaca, 1419 , fols. 128 v.-129 v. 
Esta compraventa ficticia se aclara en un documento posterior al atreudarlo a sus dueños por espacio de 20 años - con carta de gracia ${ }^{368}$ debiendo entregar 5 cahíces de trigo anuales en la festividad de San Gil de septiembre, debiendo prestar atención a las explotaciones a su cargo, es decir, «xabrir, podar, ligar, cavar, hedrar e si mester sera morgonar». Es decir, se trata de un préstamo con garantía inmobiliaria cuyo plazo de amortización coincide con el de arrendamiento y cuyos intereses son los censos anuales que se establecen en el mismo. Se sobreentiende que si los antiguos propietarios no lograsen satisfacer esta cuantía perderían la nuda propiedad de este importante complejo. Todavía no se generalizará el juramento anual realizado en la sinagoga bajo pena de aladma y nidduy sobre todo aquél que realizara préstamos usurarios contraviniendo la legislación foral ${ }^{369}$.

Algunas transacciones exceden el marco del préstamo personal y se sitúa en el ámbito del préstamo o del tráfico comercial y mercantil. No obstante, es de interés advertir que cuando se trata de cantidades más o menos respetables han de asociarse dos judíos para poder hacerlo efectivo, salvo los miembros de la mano mayor muy selectos y exclusivos. El 24-I-1410, Sancho I nneç de Sarasa, escudero, habitante en Yebra, recibe 400 sueldos de A Lonieto y Jacob Avingoyos, hijo de Sento, de una comanda que fus scrita el $18-\mathrm{XI}-1406^{370}$. La presencia de dos judíos como otorgantes también puede deberse a su asociación para la consecución de un negocio comercial o financiero común.

\footnotetext{
${ }^{368} \mathrm{AHPH}$, Protocolo 8669 , Jaca, 1419, fols. $135-135 \mathrm{v}$.

${ }^{369} 12-$ I-1479. "Juramentum judeorum. Eadem die, en la sanoga mayor de los judios de Jacca, lançada alalma e nidduy publicament por Açah Abanbron, fillo de rabi Bonaffos Azan etc. juraron los infrascriptos sobre las usuras servare foru etc. in forma etc. present Jayme Borau, bayle, etc. [Primera columna:] Sento Papur, Sento Avdali, fillode Abram, rabi Bonaffos Abanbron, adelantados; Juce Carfati, fillo de Jehuda, quondam, Faym Abanbron, fillo de Faranel, quondam, Simuel Almosnin, Bonaffos Abanbron, fillo de Acah, quondam, Baruch Carffati, menor, rabi Jehuda Almosnin, Sento Alcala, Saçon Abanbron, fillo de Acah, quondam, Abram Fallipapa, Juce Avdali, Faranel Papur, Bonaffos Carffati, Junez Larros, Jehuda Abendahut, maestre Astruch Almosnin, Gento Avdali, fillo de Jassuas, Jehuda Carffati, Abram Avdali [Segunda columna:] Simuel Avdali, Sento Almosnin fillo de Mayr, quondam, Bonaffos Alnieta, Açah Almosnin, notario, Azerian Almosnin, fillo de Juce, quondam, rabi Juce Abinardut, Açah Abanbron, fillo de Bonaffos, Sento Abanbron, fillo de Azerian, quondam, rabi Baruch Carffati". AHPH, Protocolo, Jaca, 8027, fol. 5 v.

Algunas inicitiavas tomadas para investigar las usuras durante el reinado de Jaime II, serán sobreseídas o suspendidas en 1294, garantizándoles que no se procedería a la reapertura de las causas por espacio de cinco años. RÉGNÉ, History of the Jews in Aragon, doc. 2697 y 2699.

${ }^{370} \mathrm{AHPH}$, Protocolo 8666, Jaca, 1410, f, $10 \mathrm{v}$.
} 
Ocasionalmente se invierte el signo y son los judios los que han de asociarse en comandita para tramitar un préstamo a acreedores cristianos, como el caso que se trasluce de un albarán expedido el 12-X-1414, por el que el procurador de Gil Perez de Aragués, recibe 600 sueldos de Açach Avingoyos, hijo de Juce, casado con Miriam, Simuel Alcala, hijo de Saçon, maridado con Reyna, y Jacob Almosnin, hijo de Azerian, casado con Duenya $^{371}$

No se observa un clima de crispación en la actividad crediticia, antes bien al contrario, parece existir un acuerdo tácito entre acreedores y deudores para que sus diferencias - motivadas por la solicitud de condonación parcial de deudas, impago de intereses, moratorias - se dilucidaran en el ámbito de la amigable composición a través de árbitros nombrados paritariamente por las partes en conflicto ${ }^{372}$. Lo mismo sucede cuando el moroso es un concejo, como sucede el 16-X-1412, en que los árbitros Sancho Perez de Ayerbe y Jahuda Abambron, sentencian sobre tres cartas de deudo formalizadas con el concejo de Paternue, por valor de 1.200 sueldos; 300 sueldos y 5 cahíces de trigo y 2 cahíces de trigo respectivamente, de las cuales faltaban por pagar 630 sueldos. Se establecen dos plazos de amortización: 230 sueldos en el mes de abril de 1413 congelando los intereses y los 400 sueldos restantes a libre arbitrio de los deudores, si bien se irán añadiendo los interes legales establecidos dependiendo del tiempo transcurrido ${ }^{373}$. La solución es satisfactoria para ambas partes pues, por un lado, el acreedor no pierde el principal y sigue percibiendo intereses a cambio de una mora, mientras que la autoridad judicial no ejecuta los bienes de la corporación pàra hacer frente al déficit. De hecho, las actuaciones de la corte del baile en este sentido son muy poco significativas todavía ${ }^{374}$.

Las fortunas familiares afloran con motivo de las donaciones ${ }^{375}$ y de la concesión de ciertos créditos como los 4.400 sueldos de Azerian Avingoyos y Bonafos Alcala $^{376}$. La frontera de la riqueza quizás podría situarse entre aquellos que son capaces de conceder depósitos superiores al

\footnotetext{
${ }^{371}$ AHPH, Protocolo 8144, Jaca, 1414, fol. $45 \mathrm{v}$.

${ }^{372}$ AHPH, Protocolo 8666, Jaca, 1410, fols. 26 v. -27.

${ }^{373} \mathrm{AHPH}$, Protocolo 8113, Jaca, 1412, fols. 50-50 v.

${ }^{374}$ Fritz BAER, Die Juden im Christlichen Spanien, vol. I, p. 196

${ }^{375}$ AHPH, Protocolo 8667, Jaca, 1413, fol. 31.

${ }^{376} \mathrm{AHPH}$, Protocolo 8668, Jaca, 1414, fols. 83 v. -84 .
} 
millar de sueldos ${ }^{377}$. Azerian Avingoyos, hijo de Judas, con una situación económica muy sólida, se permite el préstamo a Enyego de Gavin, habitante en Biescas, y Domingo de Gaço y su mujer Domenia, de 16 onzas y media de plata fina ${ }^{378}$. Mucho más elocuentes son sus créditos en oro -expresado en otro modo, en florines de oro cel cuño de Aragón-. El 26-XII-1418, Garcia Scartín, habitante en Jaca, le restituirá 15 del montante principal que ascendía a 20 florines $^{379}$; el 30-VI-1419, Betran Ferrero, vecino de Biescas, hace entrega de 35 florines $^{380}$, etc.

Un integrante del clan de los Avingoyos, Azerian, hijo de Jacob, da un salto cualitativo emitiendo capital a favor de concejos cristianos cantidades que casi ningún judío de la aljama era capaz de poseer. El 1-IX-1413 los jurados del lugar de Lanuza juran pagarle 2.500 sueldos a coto del rey, es decir, 2 sueldos por libra prestada, que habrán de hacer efectivo en el día de San Bartolomé ${ }^{381}$. Otro de los potentados de la comunidad es. Bonafos Alcala, hijo de Juce, quien presta a los mismos jurados otros 2.500 sueldos que se incrementarán con el preceptivo interés «tanto quanto aquellos tengan» ${ }^{382}$. Jehuda Abambrón concertó un censal de 900 sueldos anuales, pagaderos en tres tandas iguales, con los jurados de Biescas $^{383}$.

En un plano más modesto, Juce Abendavid, el 15-VI-1417, efectúa las diligencias de cobro al concejo de Piedrafita de los 114 florines de oro que les cedió en una carta de deudo ${ }^{384}$.

\footnotetext{
${ }^{377}$ AHPH, Protocolo 8667, Jaca, 1413, fols. 27-27 v. Valorado en 1.100 sueldos.

En ocasiones no tienen por qué superar estas cuantías, como los 550 seldos emitidos el 30-III-1414 por Pedro Dona Martha, vecino de Sallén, y Pedro Duaso, vecino de Jaca [AHPH, Protocolo 8114 , Jaca, 1414, fols. 21-21 v.]

No siempre los judíos se colocan en situación de acreedores, asi lo demuestran algunos albaranes rescisorios de deudas. El 20-IV-1419 Gento Avdali y su hermano Jassuas restablecen 1.050 sueldos de los 1.700 que Pero Sparça les había encomendado cuatro meses antes, en lo que puede entendenderse como un préstamo comercial [AHPH, Protocolo 8669, Jaca, 1419, fol. $59 \mathrm{v}]$.

${ }^{378}$ AHPH, Protocolo 8667, Jaca, 1413, fol. 36. 26-III-1413.

${ }^{379} \mathrm{AHPH}$, Protocolo 8669 , Jaca, 1419 , fol. 1.

${ }^{380} \mathrm{AHPH}$, Protocolo 8669, Jaca, 1419, fols. 84 v. -85 .

${ }^{381} \mathrm{AHPH}$, Protocolo 8720, Jaca, 1413, fols. 38 v. -39 .

${ }^{382}$ AHPH, Protocolo 8720, Jaca, 1413, fols. 39 v.

${ }^{383} \mathrm{AHPH}$, Protocolo 8669 , Jaca, 1419 , fols. 65 v. \& 69.

${ }^{384} \mathrm{AHPH}$, Protocolo 8115, Jaca, 1416, fol. 23.
} 
Muy contadas son las familias, que se permiten la adquisición de censales por el elevado desembolso que esto significaba. Por otro lado los acreedores preferían ir al mercado oscense con intereses más competitivos y mayores disponibilidades numerarias. El 24-IX-1415, Falbuenya, viuda de Menahem Ampifaz, recibe de los jurados de Anso 1.000 sueldos como usufructuaria y legataria de 11.700 sueldos de propiedad de un censal ${ }^{385}$.

Los cobros de adeudos también nos ponen sobre la pista de las grandes fortunas de alguna de estas familias que componen la aristía social. El 1-IX-1413 Bonafos, procurador de los herederos de Menahem, recibe 3.700 sueldos de los 6.000 prestados al concejo de Lanuz, a reservándose el derech oa reclamar los 1.300 sueldos restantes en la festividad de San Miguel de septiembre ${ }^{386}$.

El análisis de las 26 operaciones de préstamo recogidas por Alamán en 1410 y en 1413 no pueden ser más reveladoras. Hemos de dejar patente que la muestra estadística no permite realizar grandes extrapolaciones pero sí efectuar reflexiones de interés sobre la actividad crediticia de los judíos de esta localidad ${ }^{387}$.

En cuanto al plazo de amortización hemos de asertar que no se contemplan períodos superiores a un año - salvo muy excepcionalmente- . $\mathrm{Si}$ nos atenemos a los datos del ejercicio de 1410 contenido en el notario referido, de las 25 operaciones cuyo plazo nos es conocido, 11 se circunscrien a un trimestre y 8 a un semestre ${ }^{388}$; lo que traducido en términos porcentuales significa un $44 \%$ y $32 \%$, respectivamente. Aquellos que se conceden entre 7 y 9 meses suponen un número de $4-16 \%$-, mientras que los que superan esta duración son exactamente la mitad -2- que significan un $8 \%$.

En lo que acontece respecto a 1413 las diferencias cualitativas son mínimas, aunque el centro gravitatorio como veremos se sitúa en el ecuador. De los 55 créditos registrados 8 lo son a tres meses o menos -14,55\%-; mientras que los situados entre 4 y 6 meses se encaraman al $34,55 \%$ y los que se hallan entre 7 y 9 meses monopolizan un $40 \%$; los que superan esta

\footnotetext{
${ }^{385}$ AHPH, Protocolo 8721, Jaca, 1415, fol. 31.

${ }^{386}$ AHPH, Protocolo 8720, Jaca, 1413, fol. 40.

${ }^{387}$ Cuadro $^{\circ}$. 4. Judíos acreedores de la aljama de Jaca en los ejercicios 1410, 1413 y 1419.

${ }^{388} \mathrm{El}$ intervalo de clase del semestre, por ejemplo, incorpora el período comprendido entre los 4 y 6 meses o fracción, esto es, se incluyen los 6,5 meses en esta categoría y no en el siguiente.
} 


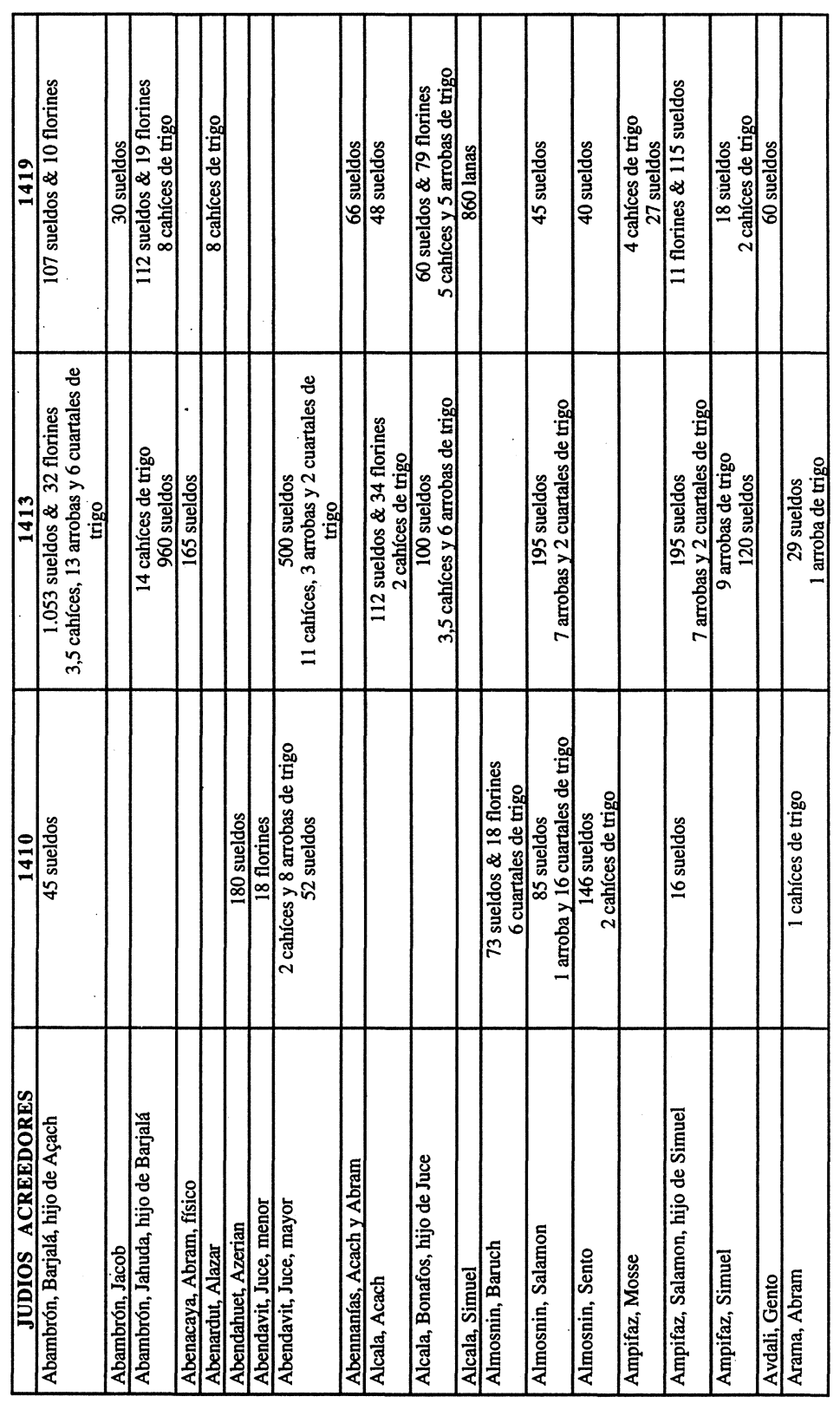




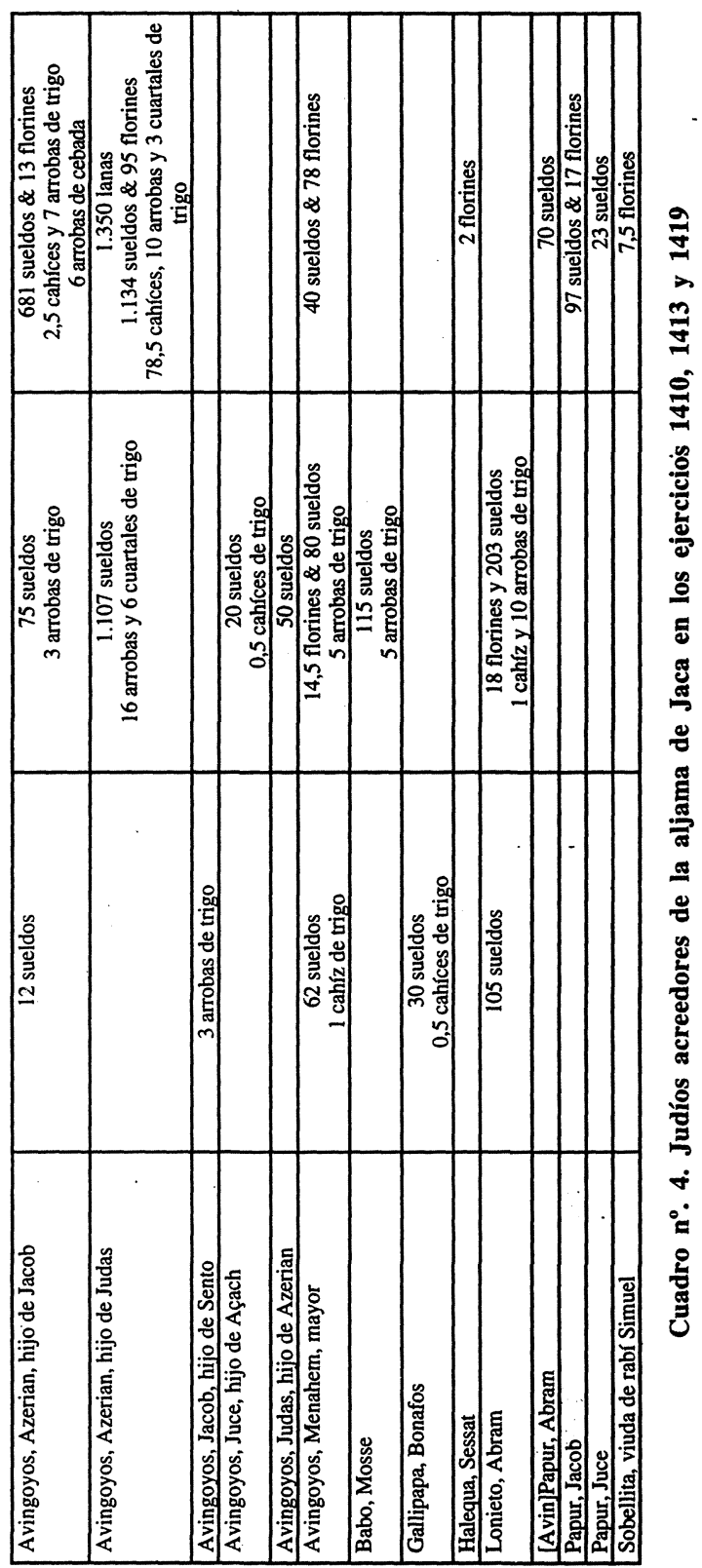


magnitud $-6-$ no llegan al $11 \%-10,91 \%$ exactamente- Mientras en 1410 los préstamos cuyo plazo de amortización no desbordaba el semestre significan un $76 \%$-es decir, las $3 / 4$ del total- en 1413 ese porcentaje -un $74,55 \%$ - lo comandan los que se finiquitan entre 4 y 9 meses. Con ello se demuestra, al menos en lo que concierne a la liquidación de la deuda, su carácter intraanual y estacional.

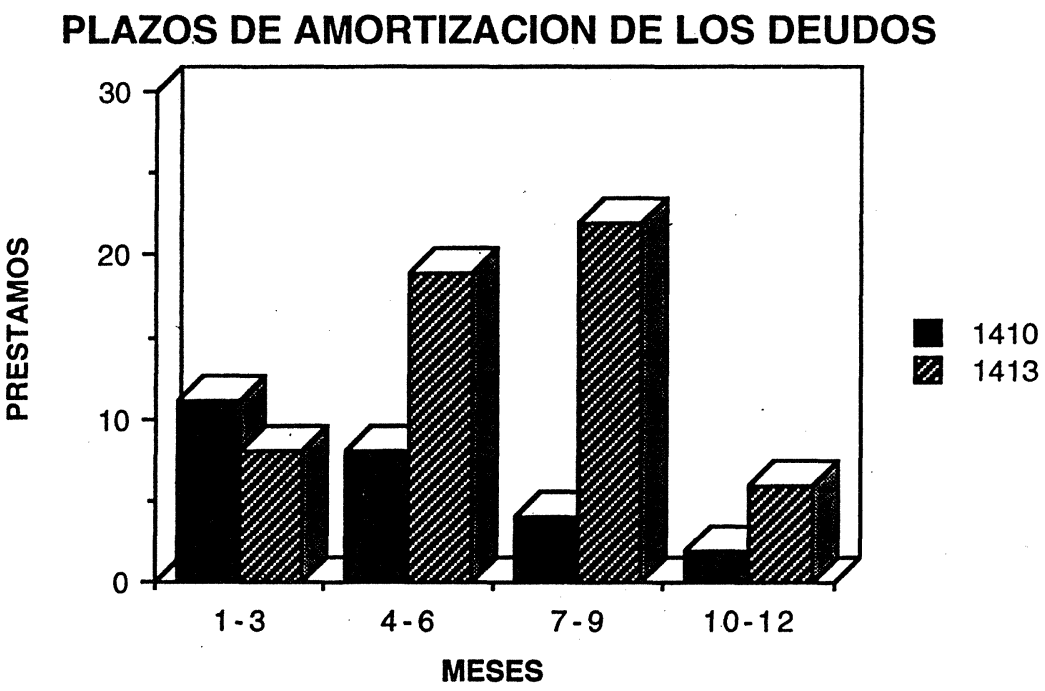

Gráfico 4

La fecha exacta de su devolución - no ya su duración en el tiempoasí como el momento de su expedición, corrobora su carácter estacional y coyuntural. Reflejemos primero los porcentajes en que los capitales -en efectivo o en especie- son requeridos por los deudores:

\begin{tabular}{lrr} 
Meses & \multicolumn{1}{c}{1410} & 1413 \\
Enero & $3,85 \%$ & $22,64 \%$ \\
Febrero & $11,54 \%$ & $15,09 \%$ \\
Marzo & $15,38 \%$ & $28,30 \%$ \\
Abril & $7,69 \%$ & $3,77 \%$ \\
Mayo & $11,54 \%$ & $1,89 \%$
\end{tabular}




$\begin{array}{lrr}\text { Junio } & 11,54 \% & 3,77 \% \\ \text { Julio } & 23,08 \% & 0,00 \% \\ \text { Agosto } & 23,08 \% & 0,00 \% \\ \text { Septiembre } & 0,00 \% & 3,00 \% \\ \text { Octubre } & 3,85 \% & 11,32 \% \\ \text { Noviembre } & 7,69 \% & 7,55 \% \\ \text { Diciembre } & 3,85 \% & 0,00 \%\end{array}$

No cabe duda de una clara bipartición cuyo eje descansa en el mes de julio. En el primer semestre - el polo principal de adjudicación- se concentra la gran mayoría de las transacciones. En 1410 hasta el mes de julio se contempla un $84,61 \%$ de la casuística, mientras que en 1413 hasta junio inclusive se incluye el $75,47 \%$. En ambas ocasiones se percibe un levísimo relanzamiento en el mes de octubre y noviembre. La evolución gráfica de las cuantificaciones anteriores queda plasmada en el gráfico inferior.

EVOLUCION ANUAL DE LOS DEUDOS SUSCRITOS EN 1410 Y 1413

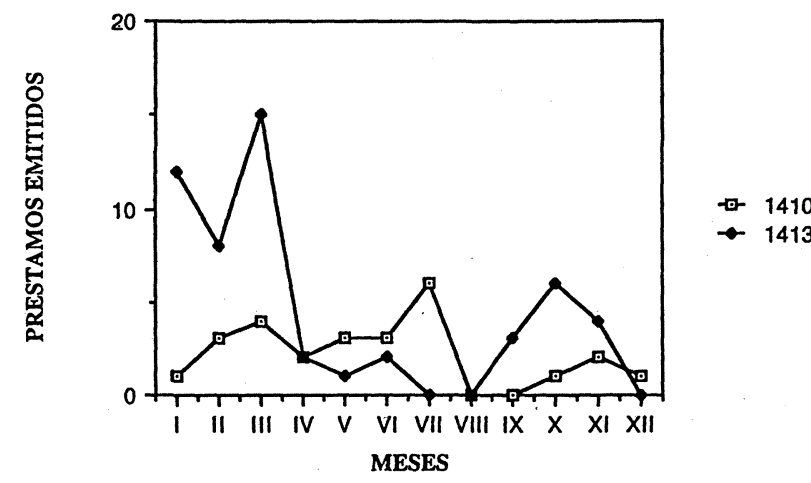

Gráfico 5

Más significativo aún, si cabe, son las fechas previstas de vencimiento que, como era previsible, coinciden con la contracción del crédito por los motivos que enseguida adelantaremos.

$\begin{array}{lccc}\quad \text { Festividades } & \text { Fecha } & 1410 & 1413 \\ \text { Pascua Florida } & \text { circa III-IV } & 3,85 \% & 5,81 \% \\ \text { Santa Cruz } & 25-\mathrm{V} & 7,69 \% & 2,33 \%\end{array}$




$\begin{array}{lccr}\text { S. Juan } & \text { VI } & -- & 2,33 \% \\ \text { S. Pedro } & 29-\text { VI } & 3,85 \% & 12,79 \% \\ \text { S. Bartolomé } & 24-\text { VIII } & -- & 4,65 \% \\ \text { S. Gil } & \text { 1-IX } & 26,92 \% & 44,19 \% \\ \text { S. Miguel } & 29-\text {-IX } & 46,15 \% & 22,09 \% \\ \text { Todos los Santos } & 1-X I & 3,85 \% & -- \\ \text { S. Martín } & 20-\text { XI } & -- & 2,33 \% \\ \text { S. Andrés } & 30-\text { XI } & -- & 2,33 \% \\ \text { Navidad } & 25-X I I & 3,85 \% & -- \\ \text { Indeterminado } & & 3,85 \% & 1,16 \%\end{array}$

Si hacemos un breve recorrido por los datos compulsados percibimos una realidad cierta incontestable: un porcentaje muy alto de pagos se efectúa en el mes de septiembre en la celebración de San Gil y San Miguel -73,07 y $66,28 \%$ - fecha en la que se ha llevado a cabo el trasquileo del ganado lanar, se ha cosechado el cereal y se ha vendimiado la uva, es decir, el momento en que los deudores disponen de capital con qué atender la solicitud de adelantados que habían relizado. La festividad de San Pedro tiene cierta significancia pues en ella se celebra la feria de Jaca.

Las necesidades crediticias irán incrementándose conforme avanza el invierno y en los meses previos a la recolección donde estallan frecuentemente crisis de subsistencia o carencias coyunturales que son afrontadas gracias al dinero judío que en este campo juega un papel insustituible y encomiable, pues difícilmente se hallan otros acreedores que con un alto riesgo de insolvencia de sus destinatario se brinden a adelantar cantidades por pequeñas que sean.

Sin embargo, los componentes varían ostensiblemente si nos trasladamos al año 1419 y observamos la evolución de las comandas, es decir de los intercambios mercantiles y monetarios, no ya sólo del crédito que hasta ahora nos ocupaba exclusivamente. Entre los meses de enero y mayo apenas se llega a un 3\%, mientras que los índices se disparan a partir de junio $(17,27 \%)$, manteniéndose relativamente uniformes hasta fin de año: julio $(10,90 \%)$, agosto $(10,90 \%)$, septiembre $(13,63 \%)$, octubre $(19,09 \%)$, noviembre $(16,64 \%)$ y diciembre $(9,09 \%)^{389}$. Con ello se demuestra, por 1419.

${ }^{389}$ Cuadro $\mathrm{n}^{\mathrm{o}} .5$. Balance de la actividad mercantil de los judíos de Jaca en el ejercicio fiscal 


\begin{tabular}{|c|c|c|}
\hline MESES & SALDO ACREEDOR & SALDO DEUDOR \\
\hline Enero & {$[\ldots]$} & 124 sueldos 5 dineros \\
\hline Febrero & {$[\ldots]$} & {$[\ldots]$} \\
\hline Marzo & {$[\ldots]$} & 4 quintales de lana \\
\hline Abril & {$[\ldots]$} & 112 sueldos \\
\hline Mayo & {$[\ldots]$} & {$[\ldots]$} \\
\hline Junio & $\begin{array}{c}225 \text { sueldos \& } 63 \text { florines } \\
30 \text { cahíces } 7 \text { arrobas de trigo }\end{array}$ & 584,5 sueldos \& 24 florines \\
\hline Julio & $\begin{array}{c}57 \text { florines \& } 45 \text { sueldos } \\
18,5 \text { cahíces de trigo } \\
6 \text { arrobas de cebada }\end{array}$ & 50 sueldos \\
\hline Agosto & $\begin{array}{c}552 \text { sueldos \& } 35 \text { florines } \\
6 \text { cahíces de trigo }\end{array}$ & 36 florines \\
\hline Septiembre & $\begin{array}{c}868 \text { sueldos \& } 66 \text { florines } \\
8,5 \text { cahíces } 6 \text { cuartales }\end{array}$ & $\begin{array}{c}4 \text { cahíces de trigo } \\
90 \text { florines } \\
\end{array}$ \\
\hline Octubre & $\begin{array}{c}17 \text { cahíces de trigo } \\
620 \text { sueldos \& } 83 \text { florines } \\
150 \text { lanas } \\
\end{array}$ & $\begin{array}{c}73 \text { florines } \\
3 \text { quintales de lana }\end{array}$ \\
\hline Noviembre & $\begin{array}{c}8 \text { cahíces } 12 \text { arrobas de trigo } \\
247 \text { sueldos } \& 10 \text { florines } \\
1.980 \text { lanas } \\
\end{array}$ & 2 quintales de lana \\
\hline Diciembre & $\begin{array}{c}16 \text { cahíces } 3 \text { arrobas de trigo } \\
245 \text { sueldos \& 7,5 florines } \\
260 \text { lanas } \\
\end{array}$ & 2 cargas de lana 1 carga de añino \\
\hline
\end{tabular}

Cuadro $\mathrm{n}^{\circ}$. 5. Balance de la actividad mercantil de los judíos de Jaca en el año 1419 
ejemplo, que la actividad mercantil que se desarrolla en el último cuatrimestre del año no necesita de grandes aportes de capital judío pues sus clientes tradicionales disponen de dinero «fresco» tras vender sus cosechas, la lana o los productos manufacturados. Cuando éste deja de circular es el crédito el que pone en circulación nueva masa monetal que permite que la actividad económica no se colapse.

Respecto al nominal prestado resulta muy poco factible cuantificarlo desde el momento en que entran en liza componentes no homogéneos como la lana, el trigo - muy rara vez otras gramíneas como la cebada- y el dinero corriente o de cuenta - sueldos y florines- ${ }^{390}$. No obstante, y haciendo abstracción únicamente de los créditos donde sólo se significan cantidades en metálico -o traducibles en dinero- (13 en 1410 y 26 en 1413) llegamos a los siguientes resultados. En 1410 un $61,54 \%$ no supera los 49 sueldos; un 7,69 se sitúa entre los 50-99 sueldos, el mismo porcentaje registrado parà el intervalo de100-149 sueldos, llegando a un $23 \%$ los comprendidos entre 150 y 199 seldos. Por su parte 1413 arroja los siguientes guarismos para las cuatro categorías respectivamente: 19,23\%, 42,31\%, $26,92 \%$ y $11,54 \%$. Estos datos confirman plenamente la implantación de un crédito con emisiones de un nominal que no supera los 200 sueldos en ningún caso y que tiende a concentrarse por debajo de los 100 .

Como media en 1410 se prestan 70,75 sueldos, mientras que en 1413 se eleva a 95,75 sueldos. Nivel no muy distante a los 118,5 sueldos de las comandas registradas en 1419 que, repito, responden a supuestos distintos, por lo que no son plenamente comparables.

Tomando como referente 1419 en las operaciones realizadas únicamente con nominal monetario 3.635 sueldos se efectúa en florines de oro, lo que se traduce en cerca de un $40 \%$. Esta circulación de oro desaparecerá radicalmente a fines del siglo ${ }^{391}$.

Terminemos con un breve apunte para no hacer en exceso prolija esta disertación sobre el saldo en el tráfico de bienes, servicios y capitales - es decir, tomando comandas y deudos conjuntamente-. En los momentos de crisis política o económica la balanza comercial se muestra equilibrada o, incluso con saldo deudor para los judíos. Esta es una situación muy próxima

\footnotetext{
${ }^{390}$ Comparar con el caso de Tarazona. Miguel Ángel MOTIS DOLADER, Convulsiones finiseculares y conflictividad social: la aljama judía de Tarazona y las alteraciones de 1391, pp. 191-224.

${ }^{391}$ MotIS, Los judios de Jaca en el siglo XV, op. cit.
} 
a la que refleja la contabilidad del ejercicio de 1410 , siempre con las limitaciones que entraña que operemos sólo con la documentación conservada:

a) Acreedor: 994 sueldos 6 dineros, 50,5 florines y 15,5 cahíces, 1 arroba y 5 cuartales de trigo.

b) Deudores: 1.110 sueldos 6 dineros, 36 florines y 5 quintales y 2 cargas de lana

c) Saldo: -116 sueldos +14 florines $+15,5$ cahíces 1 arroba 5 cuartales - 5 quintales 2 cargas.

Por el contrario tres años más tarde, el panorama es mucho más esperanzador netamente favorable a las arcas hebreas: 6.544 sueldos, 16 onzas de plata, 263,5 sueldos, 50 cahíces 78 arrobas y 37 cuartales de trigo, y todo ello omitiendo la lana que merece otros considerandos.

\section{RÉSUMÉ}

Dans cet article les auteurs analysent la struture externe et interne de la Communauté juive de Jaca dans le contexte de la Dispute de Tortosa, enprenant comme référence la décennie 1410-1420 et en se basant sur ladocumentation notariale et les fonds de la Chancellerie Royale. La premièrepartie étudie les mesures restrictives de type sociales et économiques ainsi que discriminatoires prises par le Pape Benoît XIII. Avec unepopulation d'environ 425 habitants la communauté juive a une configurationpolitique consolidée dans laquelle les organes judiciaires etgouvernementaux, ces derniers sous la direction de trois adelantados, prennent de plus en plus d'importance. La société est divisée en troismains (majeure, moyenne et mineure), en fonction des critères fiscaux, où l'on perçoit la présence de corporations d'assistance. Dès le début du XVème siècle, le quartier juif commence à s'endetter et rassemble des fonds par le biais de souscriptions de redevance. Le quartier juif situé à l'origine entre la Portre de San Ginés et la Rue San Nicolás, subit un incendie ravageur en 1375 après lequel il fallut reconstruirepartiellemente les habitations. En ce qui concerne l'économie, la présencejuive a fortement marqué l'exploitation et la commercialisation de la laine et surtout l'industrie artisanale du cuir et de la chaussure. Dansl'appendice de cet ouvrage vous retrouverez les responsa du Rabbin Salamon ben Adret et Isaac ben Sheshet qui ont trait à ce Kahal.

\section{SUMMARY}

The author in this article analyse both the external and internal structure of the Jewish Community in Jaca in the context of the Dispute of Tortosa, taking as a reference point the 1410-1420 decade; and using as a basis the notarial and the Royal Chancellery 
documentation. In the first part, the restrictive social-economical and segregated measures adopted by Pope Benedict XII are studied. With a population of nearly 425 inhabitants, the Jewish quarter possessed a consolidated political configuration, where the judicial and governing institutions acquired relevance, the latter governed by three "adelantados". The society was structured in three hands (major, medium, minor), taking into account tributary criteria, thus confirming the presence of city corporations (almosna, Cabbarim). From the beginning of the 15th Century, the Jewish quarter experimented an increase in the debt acquiring resources through censual subscriptions. The Jewish quarter situated in origen between Door of Saint Ginés and Saint Nicholas Street, suffered a verocious fire in 1375 and, as a consequence, a partial reconstruction of the houses had to be carried out. There exists, in the economical area, an important Jewish presence in the exploitation and commercialization of wool, and also a clear predominance in the leather and shoes craft industries. As an appendix the responsa of Rabi Salomon ben Adret and Isaac ben Sheshet referred to our kahal are added. 


\begin{abstract}
APÉNDICE
La historia reconstruída sobre la base de fuentes externas en cualquier problemática se beneficia y complementa apelando a las fuentes internas del grupo sociológico que se analiza, recrea e interpreta. En el supuesto de los judíos medievales jacetanos estas consideraciones son todavía más evidentes. Dada la enorme variedad que revisten, las responsa son sólo una parte de éstas, no careciendo, por supuesto, de complejidad y limitaciones hermenéuticas, lo que - entendemos- exige unas notas preliminares para la comprensión de la presente colectánea.

Las responsa son fruto de un intercambio epistolar -en su mayoría con empleo de una dicción técnica y en lengua hebrea o neo-aramea- acerca de temas que se pueden describir como halakhicos, por su naturaleza religioso-jurídica. Forman un «corpus» de al menos decenas de miles, muchas de ellas en manuscritos inéditos. La institución se remonta a la época de los amoraim (hasta el siglo VI, puesto que se mencionan en la Gemara - vr. gr. Yevamot, 105a-). La remisión de la pregunta se acompañaba con una donación.

Las responsa de la Alta y Baja Edad Media que nos conciernen demuestran cierta continuidad con las originarias de la época Geónica (circa 1050), pero tienen también rasgos propios concernientes al área jurisprudencial correspondiente, con una tendencia de los copistas a la omisión deliberada de datos o información que no afectase directamente al asunto abordado, tales como los nombres propios -sustituidos por apodos genéricos que se inspiran en la Historia bíblica de los patriarcas y sus hijos (Leah, Jacob, Reuven y Simon, etc)-, la filiación de los consignatarios o los afectados, formularios, salutaciones, etc.

Afortunadamente, no todos los amanuense omitían la información en su integridad. Más aún, dentro de una misma colección hay diferencias curiales en este sentido. La correspondencia en sí era un fenómeno de integración y comunicación entre varias comunidades locales y el «epicentro" donde residía el rabino a quien iban dirigidas las cuestiones. Se advierte, sin embargo, una tendencia hacia el incremento de preguntas en las localidades cercanas a la residencia del rabino que atiende los requerimientos. Así, Adret y Barfat, en su época hispana, atienden con preferencia a las comunidades hebreas de la Corona de Aragón frente a la de Castilla.

En el ámbito peninsular debemos subrayar la institución de copiar responsa de rabinos por sus hijos o discípulos, costumbre que explica eparcialmente la riqueza
\end{abstract}


de las colecciones de este ámbito geográfico. Su importancia radica en que no se imbrican con ninguna tendencia historiográfica, esto es, no son fuentes escritas con tal fin. Reflejan por lo tanto, al azar, aspectos de la vida cotidiana que no aparecen desde esta perspectiva en otros tipos de evidencia mucho más estructurados, definidos y, por lo tanto, limitados amén de mediatizados.

La colección de responsa de Adret de Barcelona -estimadas en alrededor de diez mil expediciones-- abarca el dilatado período comprendido entre los años 1260 y 1310 , presentando muy pocos documentos explícitamente consignados a o por la aljama de Jaca. No obstante, hemos encontrado dos que sí tienen relevancia para la historia de esta comunidad. Llama poderosamente la atención la continuidad onomástica de las familias que la habitan en las dos centurias bajomedievales. De su lectura se deriva asimismo la impresión de que las casas, unas contiguas de otras, se emplazan en calles estrechas y muy próximas, con la consecuente litigiosidad en el vecindario. También resalta la fuerza y complejidad de las estructuras de gobierno autónomo comunal judío, aun cuando se trate de una colectividad no demasiado numerosa. He aquî la traducción del material con alguna relevancia histórica para nuestros propósito.

«Rabbi Salomon ben Adret, Responsa (Tel Aviv 1973) I, \#1179

$\mathrm{Al}$ ben dith (tribunal judío) de la ciudad de Huesca

Preguntásteis

Acerca del caso de Emira, hija de Rabí Ishaq ben Almosnino (?) mi enmienda por Almonist en el texto impreso, acerca de la cual hay rumores de que se ha comprometido con Moisés Elnieto de Jaca. Y enviasteis los testimonios legales escritos del beth din de Jaca. Y he visto en los testimonios escritos del beth din que vino ante vosotros Ismael, hijo de Bed, y testificó que él y Shem Tov ben Papur estaban con Moisés ben Elnieto susodicho en el techo [de la casa] de Rabí Samuel, padre del susodicho Moisés, un sábado a la noche, e Ismael se agachó e inclinó su cabeza hacia una apertura en la pared que divide este techo de la casa de Rabí Ishaq, el padre de la dicha Emira, y desde allí vio a Emira y reconoció su voz, y vio que el dicho Moisés le daba 18 monedas de su mano a la de Emira, a tenor de esponsales, y aunque la pared los dividía, ella podía oir su voz. Y Shem Tov ben Papur testificó que él estaba allí esa noche y vio una mano que salía de la apertura, y el dicho Moisés ponía dinero en la dicha mano y dijo «tú eres mi esposa»; y dijo Shem Tov... que oyó una voz que decía: «qué poco dinero es éste». Este es el tenor de sus testimonios.

También vi un testimonio escrito del Beth Din de Jaca que ellos fueron a ver la pared divisoria y el dicho techo, y se pararon allí y vieron que el espacio entre 
el techo y la pared es de dos palmas y media [medida convencional talmúdica que significa la distancia del pulgar al meñique cuando la mano está extendida al máximo] y la apertura tiene alrededor de media palma y hay sólo una apertura y está a ras de suelo. También vieron que si se introduce el brazo no se puede ver de quién es el brazo...»

«Rabbi Salomon ben Adret, Responsa III \#318.

Jaca

\section{Preguntásteis}

Se ha dictado una taqanah (ley interna) en la comunidad decidiendo castigar al que cometa pecado. Se nombraron berurin (oficiales) para esto. $\mathrm{Y}$ los berurin tienen derecho para imponer multas de dinero que perciben ellos mismos. Y ahora [ocurrió] que Leví tiene un ama judía para darle pecho a su hijo. Y esta ama fue durante los últimos días de Pascua a bañarse en el río. Y los berurin demandan a Leví una multa que le había impuesto por lo que hizo el ama. Y Leví jura sobre la Torah que no sabía nada acerca de esto, y que además el ama no es de la ciudad y no vive habitualmente con él, sino que vino con su hija de su pueblo para festejar Pascua con él. Y su hija se enfermó y una «sabia» [o curandera] le dijo que pusiera aceite y sal y que bañase a su hija, y que la tirase al río, y así se curaría. Y ella tomó a su hija para que los gentiles no creyeran que hacía brujería y la tiraba al río...».

Las alrededor de 518 responsa de Isaac ben Sheshet son de particular interés para los estudiosos de la historia de los judíos de la Corona de Aragón. Rabino en ejercicio en Barcelona, Zaragoza y Valencia, sus responsa hispanas cubren un período que se extiende aproximadamente desde el año 1368 hasta en torno al 1391.

La documentación archivística permite identificar unas tres cartas en la edición impresa de los responsa de Barfat dirigidas a Jaca. En efecto, en la edición impresa aparecen todas con el destinatario «Naqah». A. M. Hershman, en su libro Rabbi Isaac ben Sheshet Perfet and his Times (New York, 1943) no pudo identificar esta localidad e inventó una población, que no figura en ningún mapa, denominada Nakka. En tres ocasiones en su libro (pags. 107, 161, 172) se refiere a esta ciudad fantasma dotándola de pobladores, jueces y adelantados. La enmienda textual que proponemos de Nakka y Naqa en favor de Jaca es segura, no sólo porque las grafías hebreas nun y gimmel son fácilmente confundibles en la tipografía del siglo XVI, época de la «editio princeps», sino también porque Avendavit y Almosnino 
-apellidos de los destinatarios de las responsa- son nombres documentados repetidamente entre los judíos de la ciudad.

Las responsa nos descubren varios aspectos de la vida interna de la comunidad. Las relaciones entre diferentes segmentos del liderazgo son uno de ellos. En el supuesto de \# 453 los problemas dentro de la familia se extienden a otros sectores. Así, vemos que la elite rabínica difiere en lo concerniente a las normas del juramento, siendo incapaces de llegar a un acuerdo dentro de la comunidad. En consecuencia, deciden dirigirse a los adelantados para que estos envíen la pregunta a R. Ishaq bar Sheshet. En otro caso la decisión de los jueces no parece ser suficiente y Almosnino se dirige a Barfat para preguntarle si su resolución es justa. La relación entre Barfat y Almosnino según se refleja en las responsa puede que merezca escrutinio. Así, por ejemplo, en el responsum \#453 los adelantados le han escrito que los sabios de Jaca están divididos entre sí a propósito de las leyes del juramento, es decir, que en Jaca se considera el problema lo suficientemente complejo como para suscitar diferentes opiniones jurídicas.

La respuesta comienza diciendo que "el caso es claro...». Este inicio, no muy adecuado para una carta, quiere poner de manifiesto la pericia jurídica de los sabios de Jaca. Barfat agrega además, refiriéndose a una de las ideas expresadas por dichos sabios, que «el que menciona [como antecedente legal] el caso del juramento que fue parcialmente anulado se equivoca de forma radical. Este caso depende de otra cosa». Las cartas, por lo general, carecen de esos elogiosos, ampulosos y retóricos preámbulos o conclusiones que caracterizan la correspondencia de Ishaq $\mathrm{b}$. Sheshet con otras personalidades o comunidades. Así, por ejemplo \#447 remitida a Valencia y consignada a Hasday Shelomo, comienza diciendo «Señor, he visto tus últimas palabras y fueron para mi boca como la miel, las he consumido hasta la saciedad y sé que tus acciones están motivadas por el bien [literalmente: hacia el cielo]». A Shelomo Ha-Levi se dirige comenzando «mi señor preguntó» y no "preguntaste». Un responsum a Borja (432) concluye: «el que desata a las encadenados y revela los secretos desate los atados de vuestro yugo y oiga la voz de vuestras plegarias... el que está dispuesto para lo que ordenéis vuestro leal y amante Ishaq bar Sheshet». Por supuesto que no se puede descartar el factor de la transmisión de estos textos, problema bastante complejo de por sí. Sin embargo, tendríamos que explicar por qué los copistas de nada menos que tres cartas a Jaca decidieron cortar supuestas fórmulas de cortesía que no se han omitido en las cartas que mencionamos y en muchas otras más.

El mundo que nos revelan las cartas de Jaca parece orientado hacia la casa y la familia. Se trata de una familia extendida con hermanos, abuelas, etc. Puede notarse al tiempo que la mayoría de los cálculos demográficos sobre judíos hispanos no están basados en el conocimiento de la familia judía medieval, según aparece en fuentes internas como las que nos ocupan. Sin intención de generalizar, se puede apreciar, por poner un ejemplo, que las epístolas mencionan una familia compuesta 
por un hermano y una hermana, otra de un hombre sin hijos, otra de tres hermanos, etc.

En algunos momentos se disciernen elementos matriarcales en el seno familiar. Tal es el caso de una mujer es refractaria a pronunciarse en favor del matrimonio de su hija por temor a su propia madre que se opone al mismo. En otro, la madre es la fiduciaria y fideicomisaria de los bienes familiares a la muerte de su marido, según establece el Derecho sucesorio aragonés, por otra parte.

Las tensiones familiares, especialmente entre consanguíneos de segundo grados, léase hermanos, se agudizan a la hora del reparto de la herencia o de emparentar con otra familia. También la vecindad produce encono: ahí está el caso de la demanda interpuesta ante los dayyanim porque su colindante le ensucia las paredes recién pintadas con el humo de sus cocidos. Las relaciones con sus vecinos cristiano no parecen ser anómalas: se mencionan préstamos a no judíos, pero también a judíos; dos judíos adquieren una casa de una gentil, etc.

$\mathrm{La}$ propiedad se diversifica: mueble, inmueble y crédito. Como en otros lugares de Aragón y de Castilla, también en Jaca se observa una tendencia hacia la reconstrucción o reforma de las viviendas. Puede ser de interés el elemento estético en la evaluación de una obra edilicia por Almosnino. Son los espacios reducidos de la ciudad medieval en general y los de las juderías en particular los que forman el contexto de las muchas responsa dedicadas a problemas de construcción, remodelación o extensión de casas desde el siglo XII tardío hasta principios del XV.

\section{III}

«R. Isaac bar Sheshet Responsa (Jerusalén, 1975) \#453

A los adelantados (muqademim) del kahal de Jaca, su creador los proteja.

Preguntásteis:

Leah pronunció un juramento según el cual se prohibía a sí misma casarse con cierta persona sin el consentimiento de Reuven, su hermano. Sara, su madre, aprobó el juramento. Ahora, la susodicha Leah tomó quinyan y pronunció juramento por la Torah de casarse con Simón. Reuven, el hermano mencionado, aprueba y asiente. El también pronunció juramento y tomó quinyan como ella lo había hecho. Sara, su madre, ya sea a causa de su hermano o de sus parientes, ya sea por otra razón, no aprueba con sus labios y lengua en público, pero cuando le hablan en privado lo admite, lo acepta y dice que está permitido ante sus ojos, pero que teme decirlo en público por si no place a su madre y a sus hermanos, en casa de los cuales reside. $\mathrm{Y}$ acerca de este caso estalló una polémica entre los sabios de vuestra ciudad.

Unos dicen que [el juramento se puede anular...] Leah dice que cuando se le leyó el contrato de juramento prohibitivo no lo entendió en todos sus extremos, y 
además en ese momento se hallaba bajo sus manos [esto es, estaba bajo su autoridad y potestad] y la habían persuadido con falsedades. Ahora se arrepiente porque se le prohíbe casarse y porque su madre puede que la obligue a contraer nupcias con alguien que no es bueno para ella y otros argumentos semejantes.

Otros [sabios] dicen que no puede anular su primer juramento... Preguntasteis además que ya circula el rumor de que su juramento ha sido anulado... y me pedisteis que os de mi opinión acerca de todo esto.

Respuesta: el caso es claro... el que menciona [como supuesto de hecho] el caso del juramento que fue parcialmente anulado se equivoca en absoluto. Este caso depende de otra cosa... hay que ser leniente... la hija no recibió ningún beneficio de su madre a cambio de su primer juramento... la sedujeron [o engañaron] y fue seducida... estas son las palabras del que ruega etc. [por vuestra paz?]».

\section{IV}

«R. Isaac bar Sheshet Responsa \#455.

A Jaca

A Rabí Zerahia ben David (?) y a Rabí Samuel Almosnino.

Su Roca y su Salvador los proteja

Preguntásteis:

Reuven quiere construir salientes del muro exterior de su casa hacia la calle. Su vecino de callejuela se queja de que dicha callejuela es angosta y estrecha, y por eso nunca se construyeron salientes en ese vial. Además, durante las lluvias torrenciales el goteo de los salientes tan cerca del muro de su casa lo perjudicará, porque los salientes canalizarán las lluvias hacia su casa y dañarán la pared. Además quiere abrir ventanas allí y lo lesionará por «daños de observación» [léase, que verá lo que transcurra en casa del vecino, algo que según derecho talmúdico se considera un daño]. Asimismo, durante las lluvias se molestará a los que quieran entrar en su casa.

[Recordemos que los zizin -salientes- en la Mishna Ohalot 14/1 son proyecciones exteriores desde el marco de la puerta o la ventana, una especie de cobertizo o puntales, soportes bastante amplios, pues en ciertos textos, como el Yalqut se Deut 898 se puede esparcer la comida sobre ellos para un banquete rea]). 


\section{«R. Isaac bar Sheshet Responsa \#456}

Preguntásteis además

Reuven y Simon compraron de una gentil una casa y su planta alta [o buhardilla] conjuntamente. La parte que corresponde a cada uno es clara. En el momento actual cada uno de ellos había hecho construcciones en su porción, renovando y habilitando la casa. Reuven erigió una casa con su planta alta [o buhardilla], una bella construcción pintada, y Simón levantó una casa y dos pisos altos. $\mathrm{Y}$ su casa es menos agraciada que la de su compañero. $\mathrm{Y}$ todavía no han construido el muro que deben trazar para dividir la casa entre ellos. Y Simón ya ha comenzado a utilizar sus habitaciones, encendiendo fuego para su calderón, lo que había provocado que ensuciara las paredes de Reuven.

Reuven, en calidad de damnificado, solicita a los jueces (dayyanim) que prohíban [a Simón] encender el fuego allí hasta que no se levante el muro divisorio entre ambas propiedades. Y preguntasteis si es legal que los dayyanim le prohiban esto».

\section{VI}

«R. Isaac bar Sheshet Responsa \#470

A Jaca

A Rabbi Simuel ben Almosnino

Preguntaste:

Jacob tiene tres hijos, Reuven, Simón y Leví, y casó a su hijo Reuven durante su vida. Al poco tiempo murió Jacob y dejó bienes muebles e inmuebles y contratos de deudas con judíos y con gentiles, incluyendo objetos depositados como garantía de préstamos. Y dejó a la viuda, la madre de los hijos, de fiduciaria y fideicomisaria vitalicia de todos sus bienes. Uno o dos años después de la muerte del dicho Jacob, murió su hijo Reuven sin hijos. Su mujer necesitó un levir, que fue Simón, el segundo hijo. Cuando llega el momento de repartir los bienes del padre entre Simon y Levi, el primero dice que le corresponden dos partes de la propiedad de su padre: su porción y la de su hermano muerto por ser levir, ya sea de los bienes muebles como de los inmuebles como también de las deudas. Levi, el hijo menor, arguye que Simón no tiene derecho a los bienes de Reuven, puesto que su madre es la fiduciaria y comisaria de todos los bienes por disposición testamentaria de Jacob. Reuven nunca llegó a tener derecho a ellos y, por lo tanto, a fortiori, Simón tampoco ostenta ningún derecho sobre ellos". 